In cooperation with the Houston-Galveston Area Council and Texas Commission on Environmental Quality

\title{
Water-Quality, Stream-Habitat, and Biological Data for Highland and Marchand Bayous, Galveston County, Texas, 2006-07
}

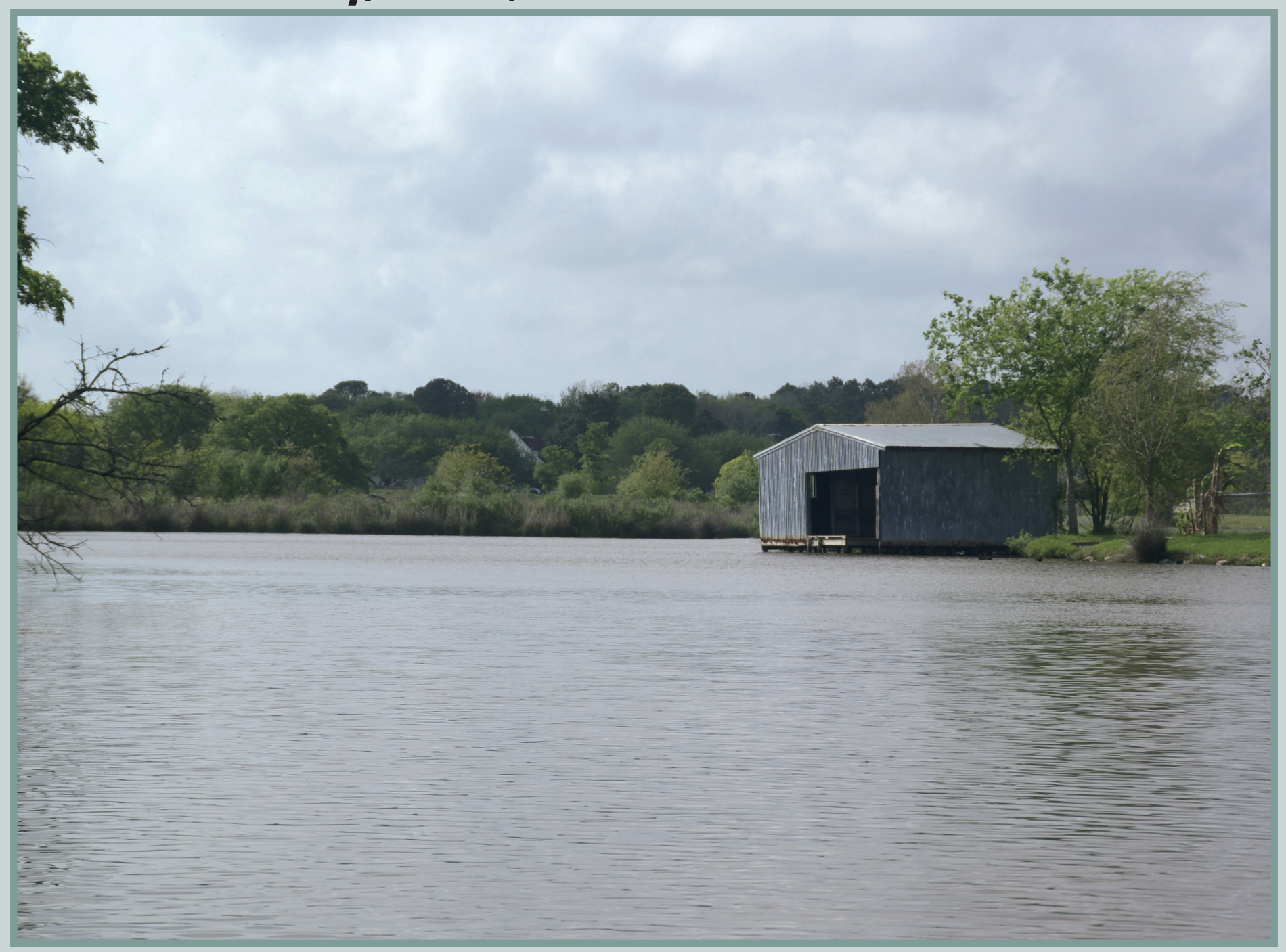

Data Series 394 
Front cover: Highland Bayou near Hitchcock, Texas, July 10, 2006. Photograph by Patrick Keefe, U.S. Geological Survey.

Back cover: Highland Bayou near Hitchcock, Texas, July 11, 2006. Photograph by Patrick Keefe, U.S. Geological Survey. 


\section{Water-Quality, Stream-Habitat, and Biological Data for Highland and Marchand Bayous, Galveston County, Texas, 2006-07}

By Dexter W. Brown, Jeffrey A. Mabe, and Michael J. Turco

In cooperation with the Houston-Galveston Area Council and

Texas Commission on Environmental Quality

Data Series 394 


\title{
U.S. Department of the Interior DIRK KEMPTHORNE, Secretary
}

\author{
U.S. Geological Survey \\ Mark D. Myers, Director
}

U.S. Geological Survey, Reston, Virginia: 2008

This and other USGS information products are available at http://store.usgs.gov/
U.S. Geological Survey
Box 25286 , Denver Federal Center
Denver, CO 80225
To learn about the USGS and its information products visit http://www.usgs.gov/
1-888-ASK-USGS

Any use of trade, product, or firm names is for descriptive purposes only and does not imply endorsement by the U.S. Government.

Although this report is in the public domain, permission must be secured from the individual copyright owners to reproduce any copyrighted materials contained within this report.

Suggested citation:

Brown, D.W., Mabe, J.A., and Turco, M.J., 2008, Water-quality, stream-habitat, and biological data for Highland and Marchand Bayous, Galveston County, Texas, 2006-07: U.S. Geological Survey Data Series 394, 61 p. 


\section{Contents}

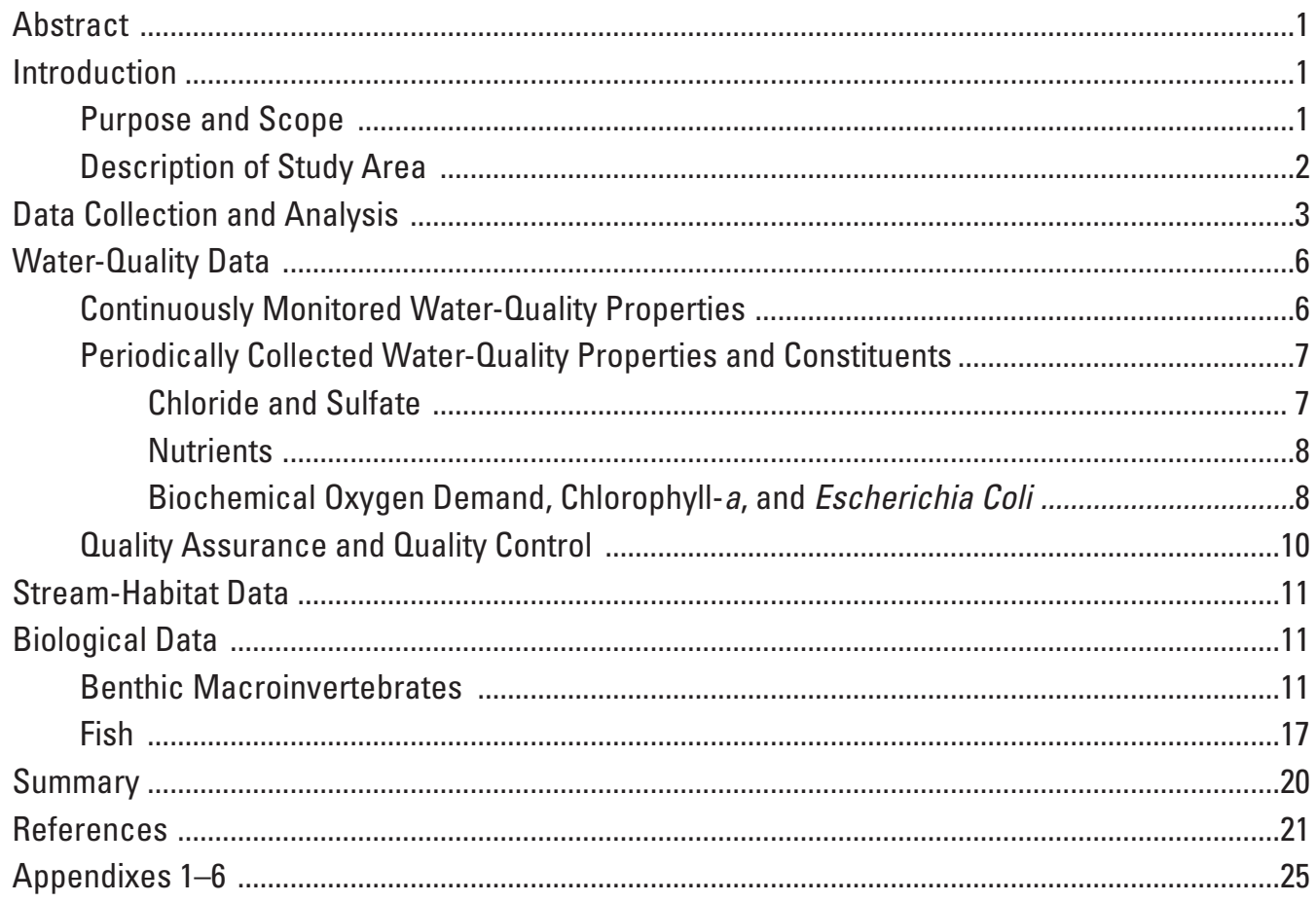

\section{Figures}

1. Map showing Highland and Marchand Bayous watershed and locations of Highland and Marchand Bayous sampling sites (reaches), Galveston County, Texas, 2006-07

2. Map showing land-cover distribution in Highland and Marchand Bayous watershed, Galveston County, Texas

3-10. Graphs showing:

3. Rainfall at National Weather Service station Jamaica Beach (COOP ID 414531), Galveston Island, Galveston County, Texas, July 2006-September 2007

4. Continuous dissolved oxygen at sites (reaches) (A) Highland Bayou at Fairwood Road, La Marque, Texas, and (B) Highland Bayou at Bayou Drive, La Marque, Texas, March 28-30, 2007

5. Distribution by site of $(A)$ chloride and (B) sulfate in samples from five sites (reaches), Highland and Marchand Bayous, Galveston County, Texas, 2006-07

6. Distribution by site of (A) ammonia plus organic nitrogen, (B) ammonia nitrogen, (C) nitrate plus nitrite nitrogen, (D) nitrite nitrogen, (E) orthophosphate phosphorus, and (F) total phosphorus in samples from five sites (reaches), Highland and Marchand Bayous, Galveston County, Texas, 2006-07

7. Distribution by site of $(A)$ biochemical oxygen demand and (B) chlorophyll-a in samples from five sites (reaches); (C) Enterococci and (D) Escherichia coli in samples from 10 sites (reaches), Highland and Marchand Bayous, Galveston County, Texas, 2006-07 
8. Relative abundance of benthic macroinvertebrates for representative reach at each of five sites, Highland and Marchand Bayous, Galveston County, Texas, 2006-07

9. Relative abundance of fish functional feeding groups for representative reach at each of five sites, Highland and Marchand Bayous, Galveston County, Texas, 2006-07

10. Number of fish collected relative to number of fish species from representative reach at each of five sites, Highland and Marchand Bayous, Galveston County, Texas, 2006-07

\section{Tables}

1. Data-collection sites (reaches) and types of data collected at each, Highland and Marchand Bayous, Galveston County, Texas, 2006-07

2. Summary of 24-hour water temperature data collected at five sites (reaches), Highland and Marchand Bayous, Galveston County, Texas, 2006-07

3. Summary of 24-hour pH data collected at five sites (reaches), Highland and Marchand Bayous, Galveston County, Texas, 2006-07

4. Summary of 24-hour specific conductance data collected at five sites (reaches), Highland and Marchand Bayous, Galveston County, Texas, 2006-07

5. Summary of 24-hour dissolved oxygen data collected at five sites (reaches), Highland and Marchand Bayous, Galveston County, Texas, 2006-07

6. Scores for stream-habitat metrics and habitat quality index for representative reach at each of five sites, Highland and Marchand Bayous, Galveston County, Texas, 2006-07

7. Scores for benthic macroinvertebrate metrics and aquatic life use for representative reach at each of five sites, Highland and Marchand Bayous, Galveston County, Texas, 2006-07

8. Scores for fish metrics and index of biotic integrity for representative reach at each of five sites, Highland and Marchand Bayous, Galveston County, Texas, 2006-07

9. Relative abundance of tolerant fish species, excluding western mosquitofish, for representative reach at each of five sites, Highland and Marchand Bayous, Galveston County, Texas, 2006-07

10. Average aquatic-life-use category indicated by stream habitat, benthic macroinvertebrates, and fish for representative reach at each of five sites, Highland and Marchand Bayous, Galveston County, Texas, 2006-07

\section{Datums}

Vertical coordinate information is referenced to North American Vertical Datum of 1988 (NAVD 88).

Horizontal coordinate information is referenced to North American Datum of 1983 (NAD 83). 


\title{
Water-Quality, Stream-Habitat, and Biological Data for Highland and Marchand Bayous, Galveston County, Texas, 2006-07
}

\author{
By Dexter W. Brown, Jeffrey A. Mabe, and Michael J. Turco
}

\section{Abstract}

The U.S. Geological Survey, in cooperation with the Houston-Galveston Area Council and the Texas Commission on Environmental Quality, collected water-quality, streamhabitat, and biological data from five sites on Highland and Marchand Bayous in Galveston County, Texas, during 2006-07. Water-quality data-collection surveys consisted of synoptic 24-hour continuous measurements of water temperature, $\mathrm{pH}$, specific conductance, and dissolved oxygen and periodically collected samples analyzed for several properties and constituents of interest. Bacteria samples were collected monthly at 10 sites on Highland and Marchand Bayous during the study. Stream-habitat data were collected at five sites three times during the study, July-August 2006, March 2007, and July-August 2007. At each site, a representative stream reach was selected. Within this reach, five evenly spaced stream transects were determined. At each transect, stream (wetted channel width, water depth, bottom material, instream cover) and riparian (bank slope and erosion potential, width of natural vegetation, type of vegetation, percentage tree canopy) attributes were measured.

Benthic macroinvertebrate and fish data were collected from the same five sites identified for habitat evaluation. Three assessments were done to account for seasonal differences in biotic distribution. Stream-habitat and aquatic biota (benthic macroinvertebrates and fish) were assessed at each site three times during the study to evaluate aquatic life use. A total of 5,126 macroinvertebrate individuals were identified at all sites. During the study, 34 species of fish representing 28 families were collected from all the sites.

\section{Introduction}

The Texas Commission on Environmental Quality (TCEQ) administers water-quality management programs with the goal of protecting, maintaining, and restoring water resources in Texas. One such program is the Texas Clean Rivers Program (CRP), which was established by the 1991 Texas Legislature (Texas Administrative Code, 2007). Under the CRP, water-quality monitoring and assessments are conducted in 23 river and coastal basins statewide through contracts with partner agencies. The Houston-Galveston Area Council (H-GAC) is the partner agency for a 13-county service area in southeastern Texas that includes the Houston metropolitan area. Every 2 years (biennium), CRP partners may perform systematic monitoring studies, whereby a variety of data are collected in water bodies that are not monitored routinely. Data from these special studies help to determine whether additional assessment is needed to evaluate human health concerns, the status of ecological conditions, or designated stream uses.

The coastal basins of Highland Bayou and Marchand Bayou in Galveston County were chosen for this monitoring study (fig. 1). Both bayous currently (2008) are listed on the 303(d) list of impaired waters in Texas for low dissolved oxygen (Texas Commission on Environmental Quality, 2008). Parts of Highland Bayou (segment 2424A) and all of Marchand Bayou (segment 2424C) also are listed as impaired because of high bacteria concentrations. To better understand the spatial and temporal variability of water quality in the two bayous, and to characterize the habitat of the streams and the status of their biological communities, the U.S. Geological Survey (USGS), in cooperation with H-GAC and TCEQ, collected data during 2006-07 to document water-quality, streamhabitat, and biological conditions in the bayous.

\section{Purpose and Scope}

The purpose of this report is to document the waterquality, stream-habitat, and biological data collected from 10 sites (reaches) on Highland and Marchand Bayous during 2006-07. Data-collection methods are described, and data are presented to compare water-quality changes at and among 


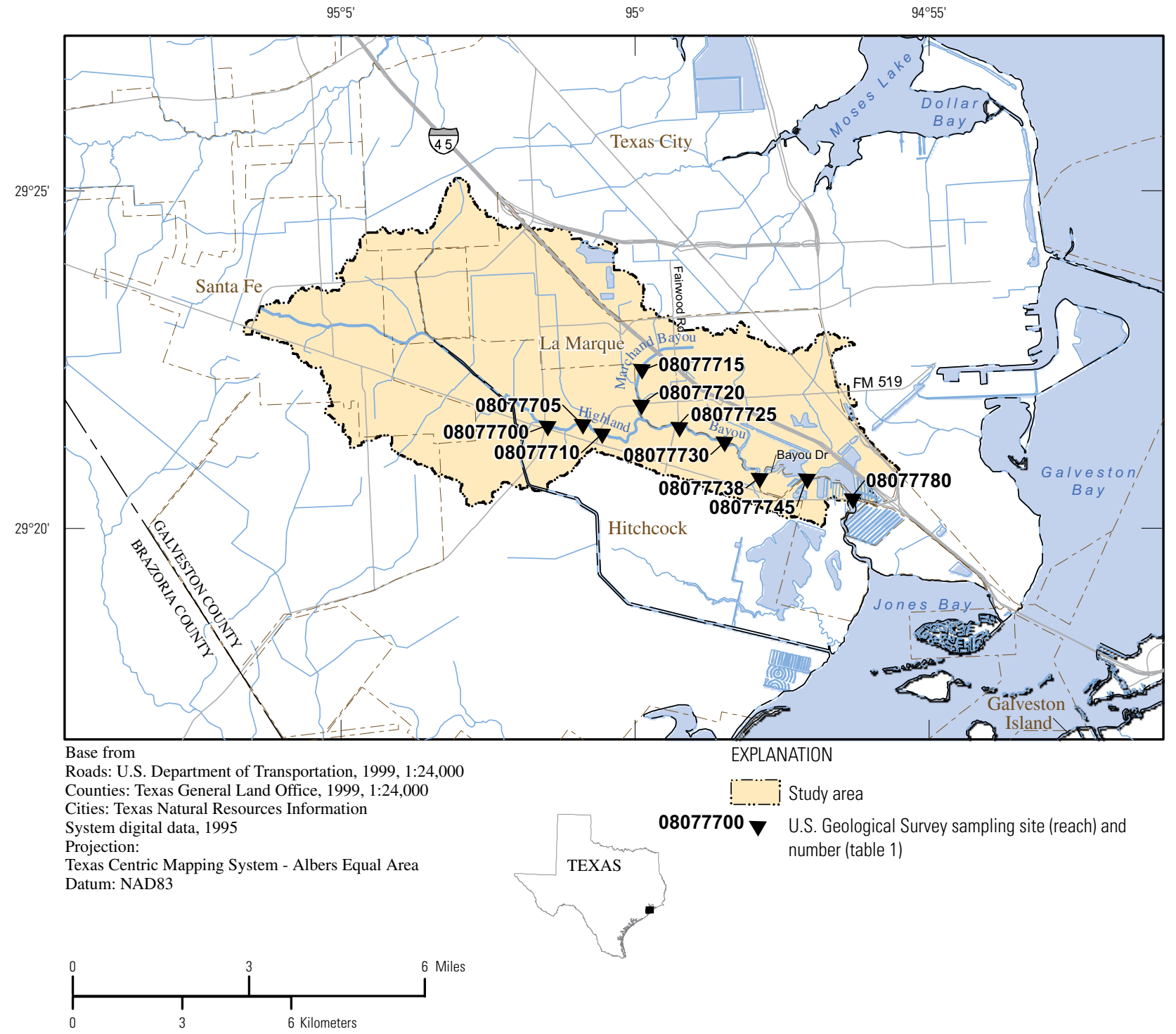

Figure 1. Highland and Marchand Bayous watershed and locations of Highland and Marchand Bayous sampling sites (reaches), Galveston County, Texas, 2006-07.

sites during the study period. In addition, water-quality data were compared to State screening thresholds for selected water-quality constituents. Metrics computed from streamhabitat and biological data were compared to State indexes for aquatic life use (Texas Commission on Environmental Quality, 2007).

\section{Description of Study Area}

Highland Bayou is a tidally influenced stream draining an approximately 39-square-mile area in Galveston County on the Texas Gulf Coast (fig. 1). The water course rises near the town of Santa Fe and runs east-southeastward about 12.6 miles to Jones Bay. Marchand Bayou is a smaller, shallower tributary that joins Highland Bayou near its mid-point. The Highland and Marchand Bayous watershed (study area) contains a mix of developed and undeveloped land (fig. 2). The upper reaches of the watershed are characterized by relatively narrow channels, steeply sloping channel sides, and low banks. Bank vegetation primarily consists of grasses, trees, and shrubs or maintained lawns. The lower reaches are characterized by relatively broad channels, a sinuate shoreline, and gently sloping channel sides that grade into shallow banks. Channel margins in the lower reaches are less developed and generally are lined with cordgrass. 


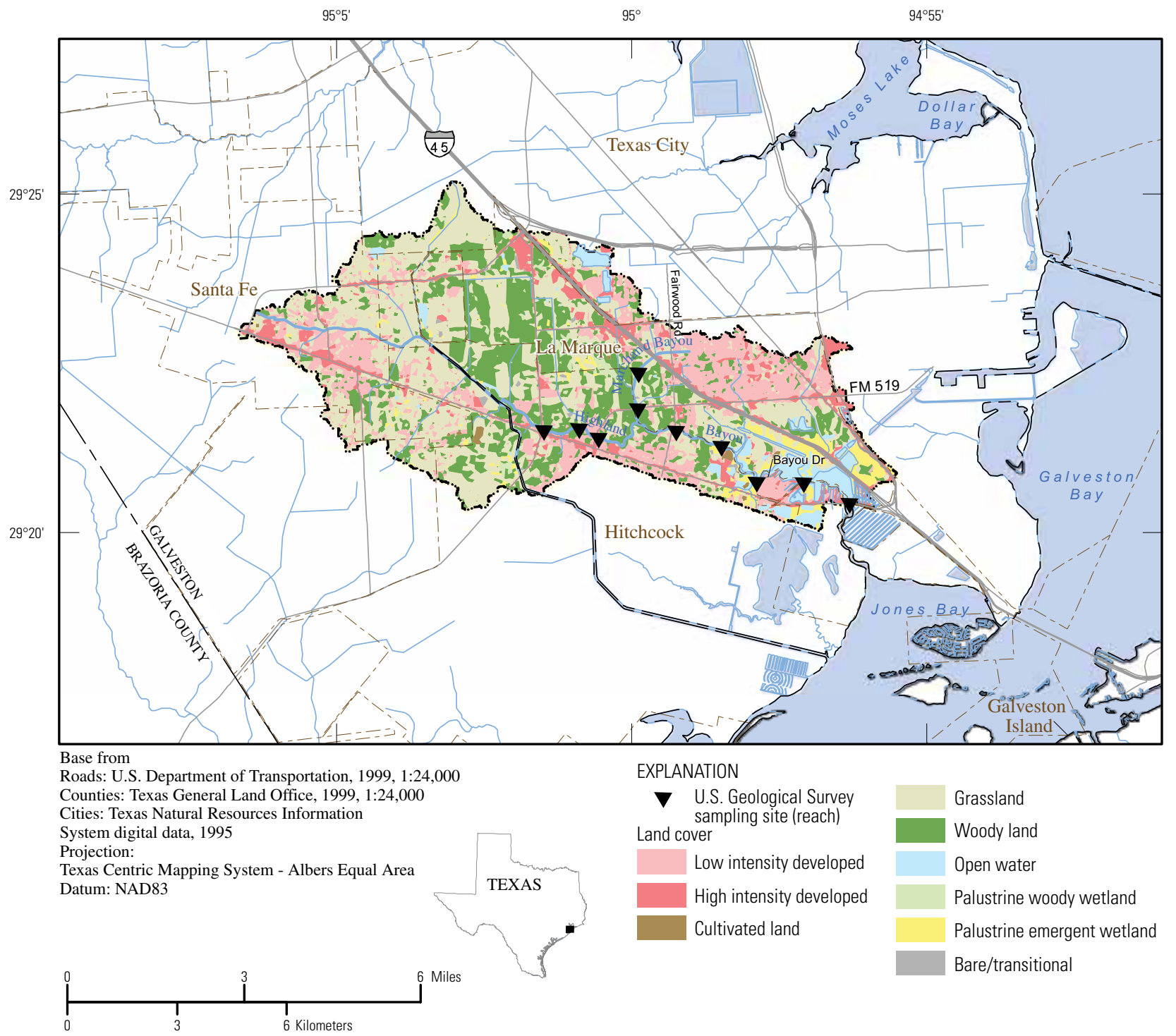

Figure 2. Land-cover distribution in Highland and Marchand Bayous watershed, Galveston County, Texas (Houston-Galveston Area Council digital data, 2002).

Climatic conditions in the study area are classified as humid subtropical (Larkin and Bomar, 1983) and characterized by cool temperate winters, long hot summers, and high relative humidity. Data from a National Weather Service station on Galveston Island about 10 miles south of Hitchcock (Jamaica Beach, COOP ID 414531) indicate weather conditions during the study period, July 2006-September 2007 (National Climatic Data Center, 2008). During the study period, mean temperatures ranged from about 55 degrees Fahrenheit $\left({ }^{\circ} \mathrm{F}\right)$ in winter (December-February) to about $83^{\circ} \mathrm{F}$ in summer (JuneAugust), with maximum temperatures frequently higher than $90{ }^{\circ} \mathrm{F}$. Total rainfall at Jamaica Beach during the 15-month study period was 96.24 inches; the maximum monthly total was 14.89 inches in October 2006, and the minimum monthly total was 0.16 inch in February 2007 (fig. 3).

\section{Data Collection and Analysis}

Data for this report were collected from 10 sites (reaches) in the Highland and Marchand Bayous watershed (fig. 1; table 1). Hereinafter, reaches are referred to by their short names as listed in table 1 . Water-quality data for this report are categorized by the way they were collected: (1) continuously monitored data — water-quality properties measured with a multiprobe instrument at each site; and (2) periodically 


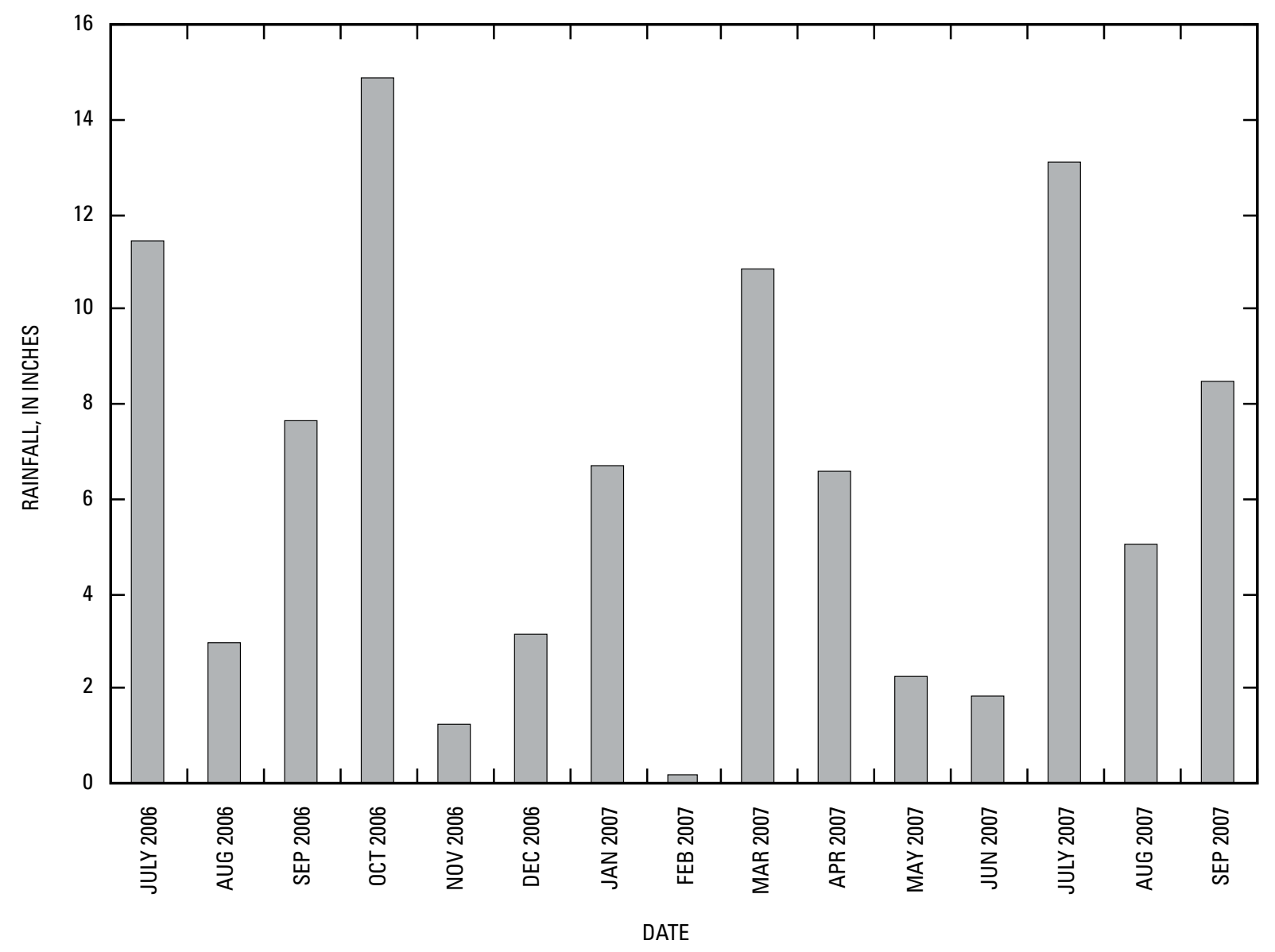

Figure 3. Rainfall at National Weather Service station Jamaica Beach (COOP ID 414531), Galveston Island, Galveston County, Texas, July 2006-September 2007.

collected data—water-quality properties and constituent concentrations obtained from analysis of discrete samples collected periodically at the sites.

Four properties (water temperature, $\mathrm{pH}$, specific conductance, and dissolved oxygen) were monitored continuously at five sites (table 1) for periods ranging from 24 hours to several days during July-October 2006, and March, May, July, and August 2007. At each site, monitors were located where depth and flow conditions were typical of the reach used for biological data collection. Properties were measured and logged by the monitors at 15-minute intervals.

The same four properties plus transparency and turbidity were measured, and the constituents listed below were sampled periodically (one to five times per month during the 2006-07 study period) at five sites (table 1):

1. Chloride and sulfate

2. Residue on evaporation and total residue

3. Nutrients (ammonia plus organic nitrogen, ammonia nitrogen, nitrate plus nitrite nitrogen, nitrate nitrogen, nitrite nitrogen, organic nitrogen, total nitrogen, orthophosphate phosphorus, total phosphorus)

\section{Total organic carbon}

5. Biochemical oxygen demand (BOD) and carbonaceous biochemical oxygen demand (CBOD)

6. Phytoplankton (chlorophyll- $a$, pheophytin- $a$ )

7. Suspended sediment

Water temperature, $\mathrm{pH}$, specific conductance, dissolved oxygen, transparency, and turbidity were measured, and the fecal indicator bacteria Enterococci, Escherichia (E.) coli, and total coliform were sampled periodically at all 10 sites.

Before sample collection, properties were measured at three sections in the stream to determine uniformity of physical conditions across the channel. Water (grab) samples were collected at the center of the stream using methods described by the Texas Natural Resource Conservation Commission (1999). All samples were maintained at less than 4 degrees Celsius $\left({ }^{\circ} \mathrm{C}\right)$ until analysis. Analyses for most constituents were done at the USGS National Water Quality Laboratory (NWQL) in Denver, Colo., using methods described in Wershaw and others (1987), Fishman and Friedman (1989), Patton and Truitt (1992, 2000), Fishman (1993), and U.S. 


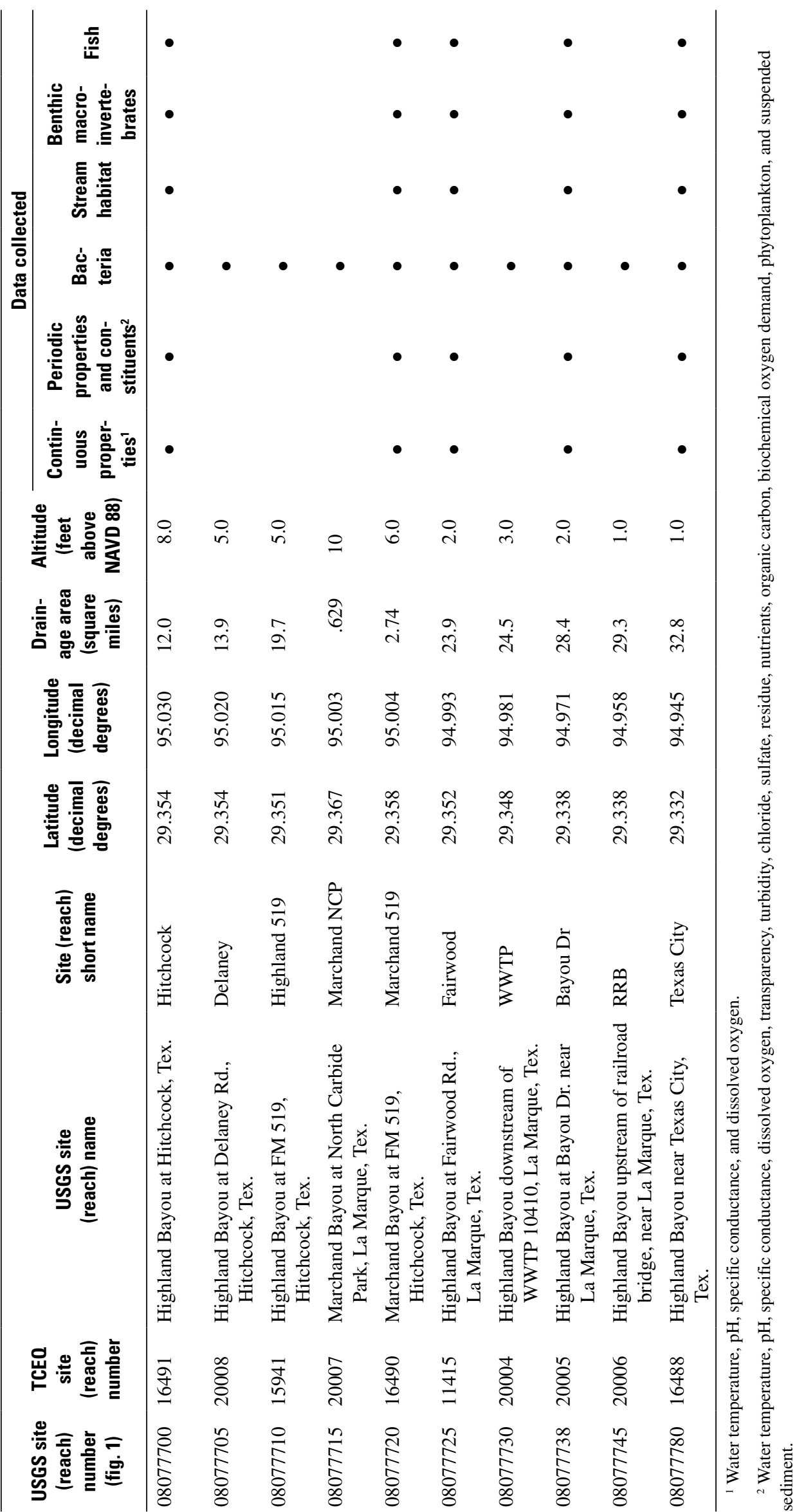


Water-Quality, Stream-Habitat, and Biological Data for Highland and Marchand Bayous, Galveston County, Texas, 2006-07

Environmental Protection Agency (1993). Analyses for BOD, CBOD (Delzer and McKenzie, 2003), and fecal indicator bacteria (Myers and others, 2007) were done at the USGS Texas Water Science Center Gulf Coast Program office. Suspended sediment concentrations were analyzed at the USGS Louisiana Water Science Center Sediment Laboratory (Guy, 1969).

Stream-habitat data were collected at five sites (table 1) three times during the study, July-August 2006, March 2007, and July-August 2007. At each site, a representative stream reach was selected (Texas Natural Resource Conservation Commission, 1999). Within each reach, five evenly spaced transects were identified. At each transect, stream attributes (wetted channel width, water depth, bottom material, instream cover) and riparian attributes (bank slope and erosion potential, width of natural vegetation, type of vegetation, percentage tree canopy) were categorized or measured. The number of stream bends and riffles and the overall aesthetic condition were determined. The dominant substrates were noted at all sites. A habitat quality index was calculated for stream-habitat data at each site to indicate aquatic-life-use scores described by the Texas Commission on Environmental Quality (2007).

Benthic macroinvertebrates were sampled at a representative reach of the same five sites (table 1) where habitat data were collected. A 9- by 9-inch Ekman dredge on a pole was used to collect samples from four separate dredge hauls from undisturbed soft sediment near mid-channel. Sediment collected by the dredge was first washed through a 0.25 -inch (0.64-centimeter) sieve to separate the benthic macroinvertebrates from any large organic debris in the sample. All large organic debris retained by the 0.25 -inch sieve was discarded after it was thoroughly washed and inspected for any remaining benthic macroinvertebrates. Samples were then processed through a 0.02 -inch (0.05-centimeter) mesh sieve to separate the benthic macroinvertebrates from the remaining sediment. Processed benthic macroinvertebrate samples were preserved in 80-percent ethanol and submitted to EcoAnalysts, Inc., in Moscow, Idaho, for taxonomic identification and enumeration. Each dredge sample underwent complete sorting and enumeration, and all benthic macroinvertebrates collected were identified to the lowest taxonomic level possible. A reference collection, with at least one specimen of each taxon identified was provided to the USGS by EcoAnalysts, Inc.

A tolerance value and functional feeding group designation were assigned to each benthic macroinvertebrate taxa as defined by TCEQ classification guidance (Texas Natural Resource Conservation Commission, 1999). Each macroinvertebrate community was assessed on the basis of metrics described in "Surface Water Quality Monitoring Procedures, Volume 2" (Texas Commission on Environmental Quality, 2007).

As part of the initial biological sampling (July 2006), the benthic macroinvertebrate sample from one site was split to create a primary sample and a replicate sample. This was done by dividing the sample into subsections and identifying and enumerating all individuals in each subsection until a minimum of 100 individuals in each subsection was obtained (Texas Natural Resource Conservation Commission, 1999).

Fish sampling (surveys) were done at a representative reach of the same five sites (table 1) where habitat data were collected. Fish were collected using a combination of seining and electrofishing (Texas Natural Resource Conservation Commission, 1999). Seining, or seine netting, involves manually pulling a large, mesh net through relatively shallow water nearshore. Seining was done with a 4.6-meter flat-panel seine with a 0.64 -centimeter mesh. Electrofishing involves the application of electrical current to the water to stun fish. Electrofishing was done with a Smith-Root 5.0 Generator Powered Pulsator electrofishing system with a maximum power output of 5,000 watts. Description of seining and electrofishing to sample fish in the reaches of Highland and Marchand Bayous is in Mabe and Moring (2008).

Seining was used where relatively high salinity precluded electrofishing. Salinity was too high for electrofishing in the two most downstream reaches that were sampled for fish (Bayou Dr and Texas City), so these reaches were sampled by seining only. In the more upstream reaches where salinity was lower (Marchand 519 and Fairwood), a combination of electrofishing and seining was used. In the uppermost reach of Highland Bayou (Hitchcock), seining was not practical because of steep banks and abundant woody debris that disrupted effective net hauling; therefore only electrofishing was used for fish sampling in this reach. After collection and identification at the stream, fish were released. Fish collected by seining were kept separate from fish collected by electrofishing for identification and enumeration so that the effectiveness of each method could be assessed.

Unidentified fish were analyzed by Dr. Dean Hendrickson, ichthyologist, at the Texas Memorial Museum at The University of Texas, Austin, for final identification and storage. A tolerance rating and trophic group were assigned to each species (Linam and Kleinsasser, 1998). An index of biotic integrity was calculated for the combined catch for each site using scoring indexes developed to assess stream fish assemblages in the Western Gulf Coastal Plain (ecoregion 34) (Linam and others, 2002).

\section{Water-Quality Data}

\section{Continuously Monitored Water-Quality Properties}

Measured water temperatures (table 2) ranged from a minimum of $22.1^{\circ} \mathrm{C}$ in March and May 2007 at Texas City and Marchand 519, respectively, to a maximum of $34.6^{\circ} \mathrm{C}$ in August 2006 at Bayou Dr. Median pH (table 3) for all sites varied from 7.1 to 8.7 . The maximum measured $\mathrm{pH}$ of 9.1 was at Fairwood in July 2006, and the minimum pH was 7.0 at Hitchcock and Fairwood in March and July 2007, 
Table 2. Summary of 24-hour water temperature data collected at five sites (reaches), Highland and Marchand Bayous, Galveston County, Texas, 2006-07.

[TCEQ, Texas Commission on Environmental Quality; --, no data]

\begin{tabular}{|c|c|c|c|c|c|c|c|c|c|c|}
\hline \multirow{2}{*}{$\begin{array}{l}\text { Site (reach) } \\
\text { short name }\end{array}$} & \multirow{2}{*}{$\begin{array}{c}\text { TCEO } \\
\text { site } \\
\text { (reach) } \\
\text { number }\end{array}$} & \multirow{2}{*}{ Statistic } & \multicolumn{8}{|c|}{$\begin{array}{c}\text { Measured water temperature } \\
\text { (degrees Celsius) }\end{array}$} \\
\hline & & & $\begin{array}{l}\text { July } \\
2006\end{array}$ & $\begin{array}{c}\text { August } \\
2006\end{array}$ & $\begin{array}{l}\text { September } \\
\quad 2006\end{array}$ & $\begin{array}{c}\text { October } \\
2006\end{array}$ & $\begin{array}{l}\text { March } \\
2007\end{array}$ & $\begin{array}{l}\text { May } \\
2007\end{array}$ & $\begin{array}{l}\text { July } \\
2007\end{array}$ & $\begin{array}{c}\text { August } \\
2007\end{array}$ \\
\hline \multirow[t]{3}{*}{ Hitchcock } & 16491 & Maximum & 30.7 & -- & 28.9 & 26.7 & 23.2 & 26.7 & 30.7 & 29.5 \\
\hline & & Minimum & 28.8 & -- & 26.3 & 26.2 & 22.4 & 25.2 & 28.6 & 28.7 \\
\hline & & Mean & 29.7 & -- & 27.5 & 26.4 & 22.8 & 25.7 & 29.4 & 29.0 \\
\hline \multirow[t]{3}{*}{ Marchand 519} & 16490 & Maximum & 31.9 & -- & 29.7 & 27.5 & 24.7 & 26.5 & 31.2 & 31.6 \\
\hline & & Minimum & 29.5 & -- & 26.8 & 27.0 & 22.8 & 22.1 & 29.4 & 30.0 \\
\hline & & Mean & 30.4 & -- & 28.3 & 27.4 & 23.7 & 24.7 & 30.1 & 30.8 \\
\hline \multirow[t]{3}{*}{ Fairwood } & 11415 & Maximum & 33.9 & 32.4 & -- & 29.2 & 25.9 & 28.7 & 28.7 & -- \\
\hline & & Minimum & 30.1 & 29.7 & -- & 27.9 & 24.4 & 26.2 & 27.5 & -- \\
\hline & & Mean & 31.8 & 30.6 & -- & 28.4 & 25.1 & 27.4 & 28.0 & -- \\
\hline \multirow[t]{3}{*}{ Bayou Dr } & 20005 & Maximum & 31.1 & 34.6 & -- & 29.0 & 26.1 & 29.2 & 31.1 & -- \\
\hline & & Minimum & 26.7 & 29.7 & -- & 26.9 & 23.4 & 25.4 & 28.5 & -- \\
\hline & & Mean & 28.4 & 31.5 & -- & 27.6 & 24.8 & 27.2 & 29.7 & -- \\
\hline \multirow[t]{3}{*}{ Texas City } & 16488 & Maximum & -- & 32.9 & -- & 29.3 & 25.1 & 26.8 & -- & 34.1 \\
\hline & & Minimum & -- & 28.9 & -- & 27.4 & 22.1 & 24.8 & -- & 31.4 \\
\hline & & Mean & -- & 30.6 & -- & 28.2 & 23.5 & 25.7 & -- & 32.7 \\
\hline
\end{tabular}

respectively. Specific conductance (table 4) generally was lower at upstream sites Hitchcock and Marchand 519 than at other sites. For all sites, specific conductance ranged from 149 microsiemens per centimeter at $25^{\circ} \mathrm{C}(\mu \mathrm{S} / \mathrm{cm})$ at Marchand 519 to $36,100 \mu \mathrm{S} / \mathrm{cm}$ at Texas City. Because available specific conductance data reflect only small time periods, the true extent of tidal influence is not indicated by the data.

Dissolved oxygen is a primary component used to evaluate the suitability of a stream to sustain aquatic life. Fish that are intolerant of low levels of oxygen become stressed when concentrations of dissolved oxygen are less than about 5 milligrams per liter (mg/L) (Fram, 2006). At levels below $2 \mathrm{mg} / \mathrm{L}$, fish kills can result. To maintain dissolved oxygen levels that will support fish, TCEQ has established mean and minimum criteria for dissolved oxygen levels in natural waters, depending on the type of stream (freshwater, intermittent, or tidal) (Texas Commission on Environmental Quality, 2003a) (table 5). The 24-hour mean dissolved oxygen criterion is $5.0 \mathrm{mg} / \mathrm{L}$ for freshwater streams, $3.0 \mathrm{mg} / \mathrm{L}$ for intermittent streams, and $4.0 \mathrm{mg} / \mathrm{L}$ for tidal streams. The minimum criterion for freshwater and tidal streams is $3.0 \mathrm{mg} / \mathrm{L}$ and for intermittent streams is $2.0 \mathrm{mg} / \mathrm{L}$. The criteria for tidal streams apply to Highland and Marchand Bayous.

Continuously monitored dissolved oxygen at all sites (table 5) was less than the respective 24-hour mean dissolved oxygen criterion for some percentage of the time in at least one monitoring period for the Hitchcock, Marchand 519, and Fairwood sites but not for the Bayou Dr and Texas City sites. Minimum dissolved oxygen concentrations at all sites were less than the respective criterion 20 to 100 percent of the time. The lowest concentrations of dissolved oxygen were measured in March 2007 at Hitchcock. Graphs of dissolved oxygen concentration from the Fairwood and Bayou Dr sites for March 28-30, 2007 (fig. 4), show diurnal patterns, although minimum concentrations were not less than the minimum criterion $(3.0 \mathrm{mg} / \mathrm{L})$ for the period shown.

\section{Periodically Collected Water-Quality Properties and Constituents}

\section{Chloride and Sulfate}

Chloride and sulfate are not used as indicators for the suitability of streams for aquatic life use; they were established in the Texas Surface Water Quality Standards to ensure support of multiple uses and as tools to identify and manage the influences of point and nonpoint sources of pollution (Texas Commission on Environmental Quality, 2003a). The 
Table 3. Summary of 24-hour pH data collected at five sites (reaches), Highland and Marchand Bayous, Galveston County, Texas, 2006-07.

[TCEQ, Texas Commission on Environmental Quality; --, no data]

\begin{tabular}{|c|c|c|c|c|c|c|c|c|c|c|}
\hline \multirow{2}{*}{$\begin{array}{l}\text { Site (reach) } \\
\text { short name }\end{array}$} & \multirow{2}{*}{$\begin{array}{c}\text { TCEO site } \\
\text { (reach) } \\
\text { number }\end{array}$} & \multirow{2}{*}{ Statistic } & \multicolumn{8}{|c|}{$\begin{array}{c}\text { Measured pH } \\
\text { (standard units) }\end{array}$} \\
\hline & & & $\begin{array}{l}\text { July } \\
2006\end{array}$ & $\begin{array}{c}\text { August } \\
2006\end{array}$ & $\begin{array}{l}\text { September } \\
2006\end{array}$ & $\begin{array}{l}\text { October } \\
2006\end{array}$ & $\begin{array}{c}\text { March } \\
2007\end{array}$ & $\begin{array}{l}\text { May } \\
2007\end{array}$ & $\begin{array}{l}\text { July } \\
2007\end{array}$ & $\begin{array}{c}\text { August } \\
2007\end{array}$ \\
\hline \multirow[t]{3}{*}{ Hitchcock } & 16491 & Maximum & 7.4 & -- & 8.3 & 7.3 & 7.2 & 7.6 & 7.5 & 7.5 \\
\hline & & Minimum & 7.3 & -- & 7.5 & 7.1 & 7.0 & 7.5 & 7.1 & 7.3 \\
\hline & & Median & 7.3 & -- & 7.6 & 7.2 & 7.1 & 7.5 & 7.2 & 7.4 \\
\hline \multirow[t]{3}{*}{ Marchand 519} & 16490 & Maximum & 7.9 & -- & 8.1 & 7.5 & 7.7 & 7.9 & 7.7 & 8.2 \\
\hline & & Minimum & 7.4 & -- & 7.5 & 7.2 & 7.4 & 7.4 & 7.5 & 7.4 \\
\hline & & Median & 7.6 & -- & 7.7 & 7.3 & 7.5 & 7.6 & 7.6 & 7.6 \\
\hline \multirow[t]{3}{*}{ Fairwood } & 11415 & Maximum & 9.1 & 8.8 & -- & 8.7 & 8.6 & 8.3 & 7.3 & -- \\
\hline & & Minimum & 7.6 & 7.4 & -- & 7.2 & 7.9 & 7.5 & 7.0 & -- \\
\hline & & Median & 8.0 & 8.0 & -- & 8.0 & 8.3 & 7.8 & 7.1 & -- \\
\hline \multirow[t]{3}{*}{ Bayou Dr } & 20005 & Maximum & 7.7 & 8.9 & -- & 8.6 & 8.1 & 8.6 & 8.3 & -- \\
\hline & & Minimum & 7.2 & 8.4 & -- & 7.9 & 7.8 & 8.0 & 7.7 & -- \\
\hline & & Median & 7.4 & 8.7 & -- & 8.2 & 8.0 & 8.4 & 7.9 & -- \\
\hline \multirow[t]{3}{*}{ Texas City } & 16488 & Maximum & -- & 8.5 & -- & 8.2 & 8.1 & 7.9 & -- & 8.3 \\
\hline & & Minimum & -- & 7.7 & -- & 7.7 & 7.9 & 7.6 & -- & 7.7 \\
\hline & & Median & -- & 8.0 & -- & 7.8 & 8.0 & 7.7 & -- & 8.1 \\
\hline
\end{tabular}

maximum chloride concentration (fig. 5) was $13,000 \mathrm{mg} / \mathrm{L}$ at Texas City, and the minimum was $30.6 \mathrm{mg} / \mathrm{L}$ at Hitchcock. The median chloride concentration from all five sites sampled was $1,160 \mathrm{mg} / \mathrm{L}$. Maximum sulfate concentration was 1,730 $\mathrm{mg} / \mathrm{L}$ at Texas City, and the minimum was $9.47 \mathrm{mg} / \mathrm{L}$ at Hitchcock. The median sulfate concentration from all sites was 165 $\mathrm{mg} / \mathrm{L}$.

\section{Nutrients}

Nitrogen compounds occur naturally in the environment, usually in small amounts in surface water, and include ammonia, organic nitrogen, nitrite, and nitrate. The largest ammonia plus organic nitrogen concentration was $120 \mathrm{mg} / \mathrm{L}$ at Bayou Dr (fig. 6; appendix 1). The median ammonia plus organic nitrogen concentration from all five sites was $0.98 \mathrm{mg} / \mathrm{L}$. The largest concentration of ammonia was $0.24 \mathrm{mg} / \mathrm{L}$, measured at Hitchcock. The median ammonia concentration from all five sites was $0.04 \mathrm{mg} / \mathrm{L}$. The largest nitrate plus nitrite concentration was $0.994 \mathrm{mg} / \mathrm{L}$ at Bayou Dr. The median nitrate plus nitrite concentration for all sites was less than $0.016 \mathrm{mg} / \mathrm{L}$.
The maximum nitrite concentration was $0.033 \mathrm{mg} / \mathrm{L}$ at Bayou Dr. The median nitrite concentration was $0.002 \mathrm{mg} / \mathrm{L}$.

Orthophosphate is an inorganic form of phosphorus that is used by plants. It is produced by natural processes and also is found in sewage (Hem, 1985). Orthophosphate concentrations were largest at Hitchcock, where the maximum concentration was $0.094 \mathrm{mg} / \mathrm{L}$ (fig. 6; appendix 1). The median orthophosphate concentration for all sites was $0.0205 \mathrm{mg} / \mathrm{L}$.

Total phosphorus includes dissolved forms as well as phosphorus attached to sediment particles and in living organisms like algae and bacteria. Total phosphorus concentrations were largest at Bayou Dr; the maximum concentration was $10.0 \mathrm{mg} / \mathrm{L}$. The median total phosphorus concentration from all sites was $0.10 \mathrm{mg} / \mathrm{L}$.

\section{Biochemical Oxygen Demand, Chlorophyll-a, and Escherichia Coli}

BOD is a measure of the oxygen consumed by bacteria from the decomposition of organic matter (Sawyer and McCarty, 1978). If the BOD of decomposition is large, 
A.

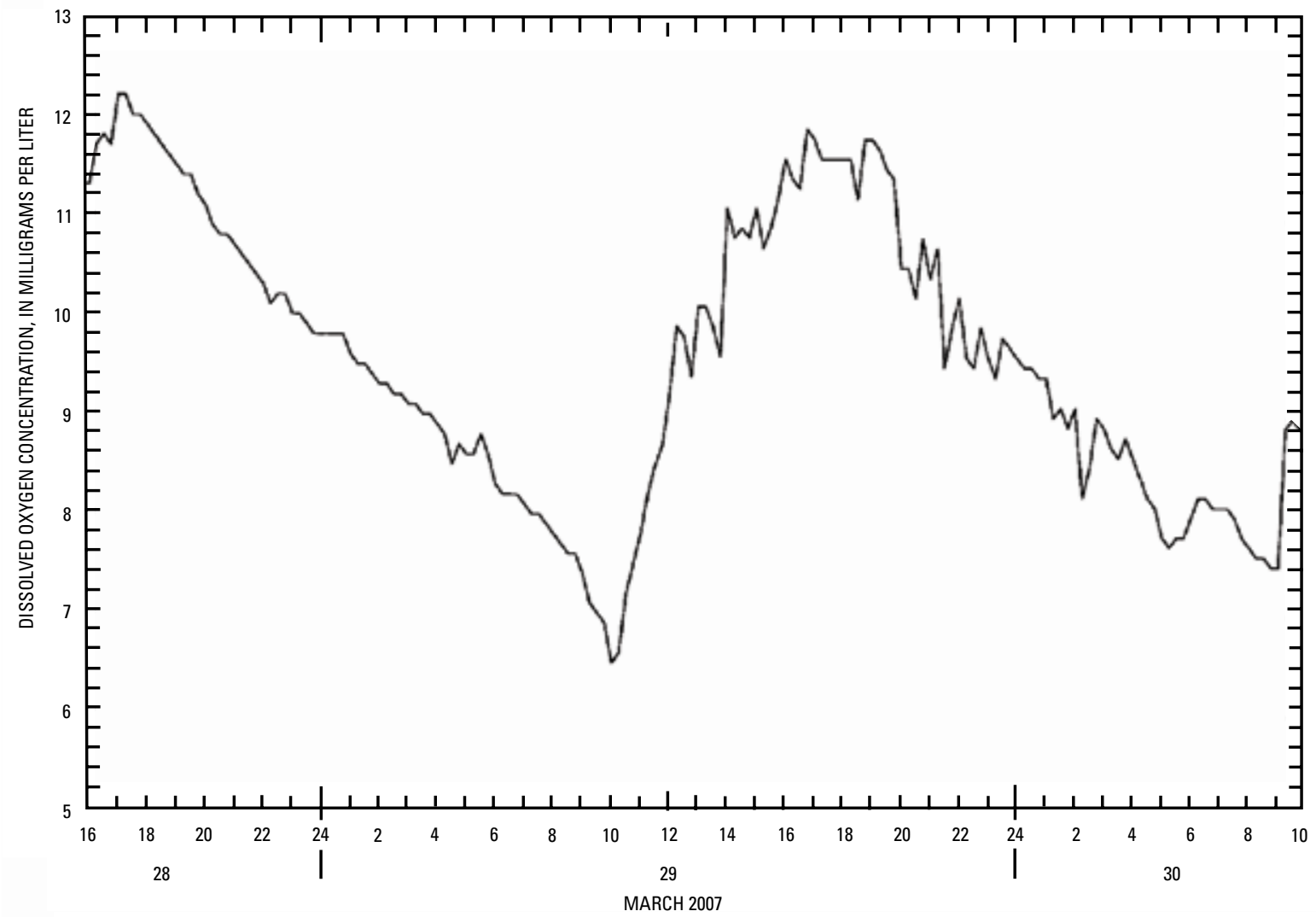

B.

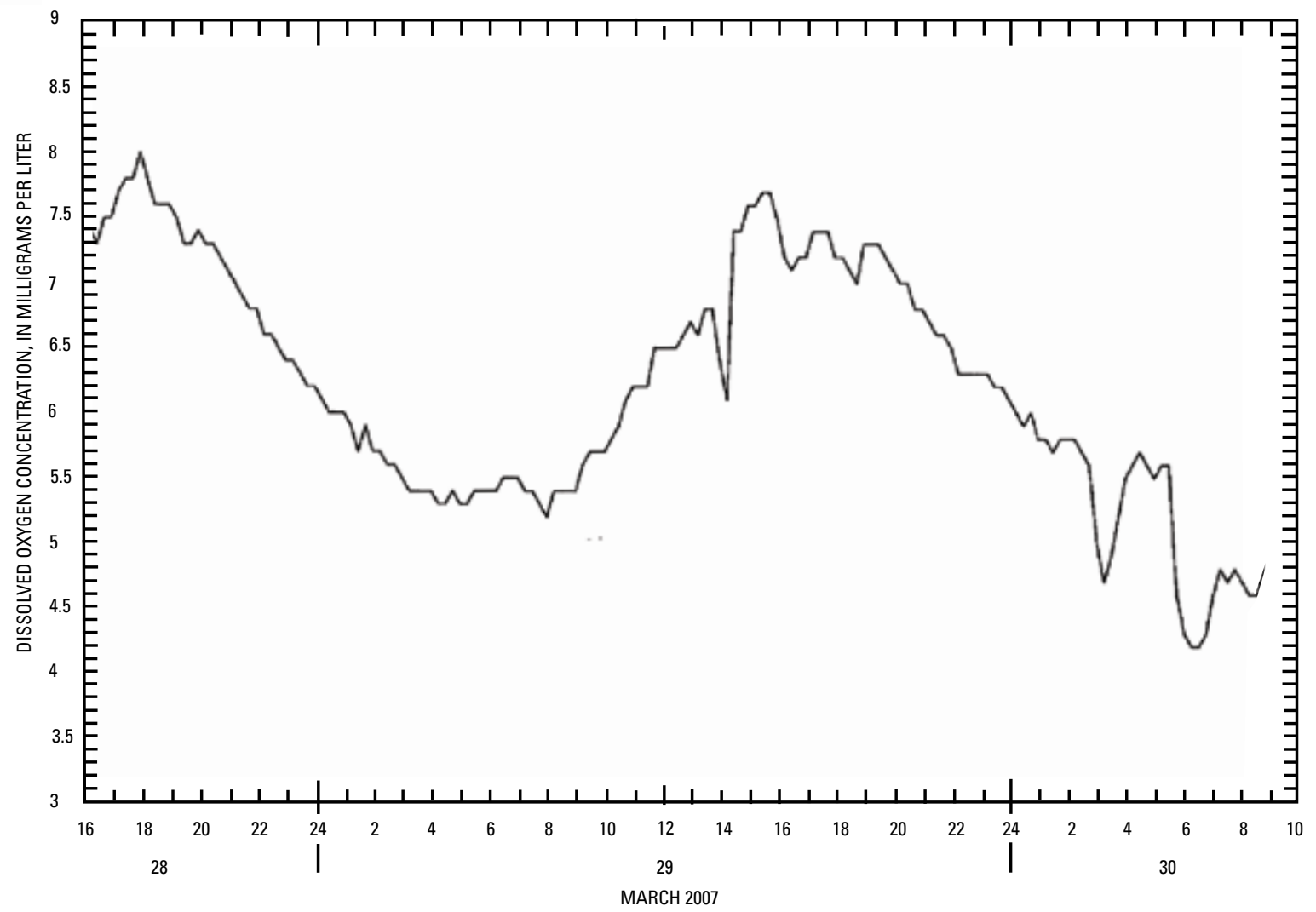

Figure 4. Continuous dissolved oxygen at sites (reaches) (A) Highland Bayou at Fairwood Road, La Marque, Texas, and (B) Highland Bayou at Bayou Drive, La Marque, Texas, March 28-30, 2007. 
Table 4. Summary of 24-hour specific conductance data collected at five sites (reaches), Highland and Marchand Bayous, Galveston County, Texas, 2006-07.

[TCEQ, Texas Commission on Environmental Quality; --, no data]

\begin{tabular}{|c|c|c|c|c|c|c|c|c|c|c|}
\hline \multirow{2}{*}{$\begin{array}{l}\text { Site (reach) } \\
\text { short name }\end{array}$} & \multirow{2}{*}{$\begin{array}{c}\text { TCEO } \\
\text { site } \\
\text { (reach) } \\
\text { number }\end{array}$} & \multirow{2}{*}{ Statistic } & \multicolumn{8}{|c|}{$\begin{array}{c}\text { Measured specific conductance } \\
\text { (microsiemens per centimeter at } 25 \text { degrees Celsius) }\end{array}$} \\
\hline & & & $\begin{array}{l}\text { July } \\
2006\end{array}$ & $\begin{array}{c}\text { August } \\
2006\end{array}$ & $\begin{array}{l}\text { September } \\
2006\end{array}$ & $\begin{array}{l}\text { October } \\
2006\end{array}$ & $\begin{array}{c}\text { March } \\
2007\end{array}$ & $\begin{array}{l}\text { May } \\
2007\end{array}$ & $\begin{array}{l}\text { July } \\
2007\end{array}$ & $\begin{array}{l}\text { August } \\
2007\end{array}$ \\
\hline \multirow[t]{3}{*}{ Hitchcock } & 16491 & Maximum & 1,100 & -- & 8,480 & 9,800 & 676 & 1,990 & 337 & 633 \\
\hline & & Minimum & 951 & -- & 4,410 & 9,020 & 631 & 1,890 & 264 & 608 \\
\hline & & Mean & 1,030 & -- & 5,540 & 9,360 & 651 & 1,940 & 314 & 616 \\
\hline \multirow[t]{3}{*}{ Marchand 519} & 16490 & Maximum & 946 & -- & 9,940 & 17,000 & 1,040 & 4,230 & 557 & 1,690 \\
\hline & & Minimum & 538 & -- & 1,000 & 7,810 & 942 & 149 & 440 & 489 \\
\hline & & Mean & 700 & -- & 4,890 & 12,500 & 1,000 & 1,500 & 483 & 920 \\
\hline \multirow[t]{3}{*}{ Fairwood } & 11415 & Maximum & 1,460 & 2,670 & -- & 13,700 & 2,510 & 9,850 & 2,810 & -- \\
\hline & & Minimum & 848 & 1,910 & -- & 7,330 & 1,600 & 1,020 & 407 & -- \\
\hline & & Mean & 1,150 & 2,240 & -- & 10,400 & 2,080 & 5,910 & 1,270 & -- \\
\hline \multirow[t]{3}{*}{ Bayou Dr } & 20005 & Maximum & 14,100 & 6,720 & -- & 24,800 & 9,720 & 9,790 & 4,370 & -- \\
\hline & & Minimum & 2,410 & 2,880 & -- & 13,400 & 1,010 & 1,010 & 2,390 & -- \\
\hline & & Mean & 5,100 & 4,250 & -- & 20,200 & 1,820 & 3,090 & 2,950 & -- \\
\hline \multirow[t]{3}{*}{ Texas City } & 16488 & Maximum & -- & 3,560 & -- & 36,100 & 2,560 & 2,640 & -- & 2,290 \\
\hline & & Minimum & -- & 2,060 & -- & 27,600 & 1,650 & 2,000 & -- & 1,540 \\
\hline & & Mean & -- & 3,000 & -- & 34,400 & 2,140 & 2,240 & -- & 2,040 \\
\hline
\end{tabular}

dissolved oxygen concentrations can be close to zero. The largest measured BOD $(8.1 \mathrm{mg} / \mathrm{L})$ was at Bayou Dr (fig. 7; appendix 1) in August 2006. The median BOD concentration from all five sites was $3.7 \mathrm{mg} / \mathrm{L}$.

Chlorophyll- $a$ is a photosynthetic pigment in algae and other green plants. The concentration of chlorophyll- $a$ is used to estimate the amount of phytoplankton in a water body (Porter and others, 1993). Some concentrations of chlorophyll$a$ were more than and some were less than the applicable State screening level for tidal streams, 19.2 micrograms per liter $(\mu \mathrm{g} / \mathrm{L})($ Texas Commission on Environmental Quality, 2003a, table 18) at four of the five sites sampled (fig. 7; appendix 1); at Bayou Dr, all chlorophyll- $a$ concentrations were greater than the screening level. The maximum chlorophyll- $a$ concentration was $62.6 \mu \mathrm{g} / \mathrm{L}$ at Hitchcock. The median concentration from all sites was $24.8 \mu \mathrm{g} / \mathrm{L}$.

E. coli is a fecal indicator bacteria used to signal the potential presence of harmful pathogens in the water that come from warm-blooded animals. E. coli densities occurred over a wide range and commonly exceeded 394 most probable number per 100 milliliters (MPN/100 mL), the State single-sample value for evaluating contact and non-contact recreation use support (Texas Commission on Environmental Quality, 2003a, table 6) (fig. 7; appendix 2). The largest concentration (46,000 MPN/100 mL) was measured at Hitchcock. The median density from all 10 sites sampled was $310 \mathrm{MPN} / 100 \mathrm{~mL}$.

\section{Quality Assurance and Quality Control}

All sample collection and processing, data management, and documentation followed guidelines of the Texas Natural Resource Conservation Commission (1999) and the Texas Commission on Environmental Quality (2003b). The guidelines are included in the Quality Assurance Project Plan (Jean Wright, Houston-Galveston Area Council, written commun., 2005).

Quality control (QC) samples, consisting of a field blank and replicates (appendix 3), were used to evaluate the extent to which contamination, characteristics of the water (matrix), and measurement variability affected analytical results (Mueller and others, 1997). Further explanation of QC sample types and their use are described by Mueller and others (1997).

Several field blanks were collected and processed at the site, immediately before the associated environmental sample, to identify potential contamination from data collection. No concentrations of any constituent exceeded the minimum reporting level for that constituent. Additional water was collected during the study to split into two samples; one was designated as the environmental sample and the other was a split replicate of that sample. Analytical results from each sample set were compared by computing the relative percentage difference (RPD) for each constituent. The RPD, specified 
Table 5. Summary of 24-hour dissolved oxygen data collected at five sites (reaches), Highland and Marchand Bayous, Galveston County, Texas, 2006-07.

[TCEQ, Texas Commission on Environmental Quality; n/a, not applicable; --, no data]

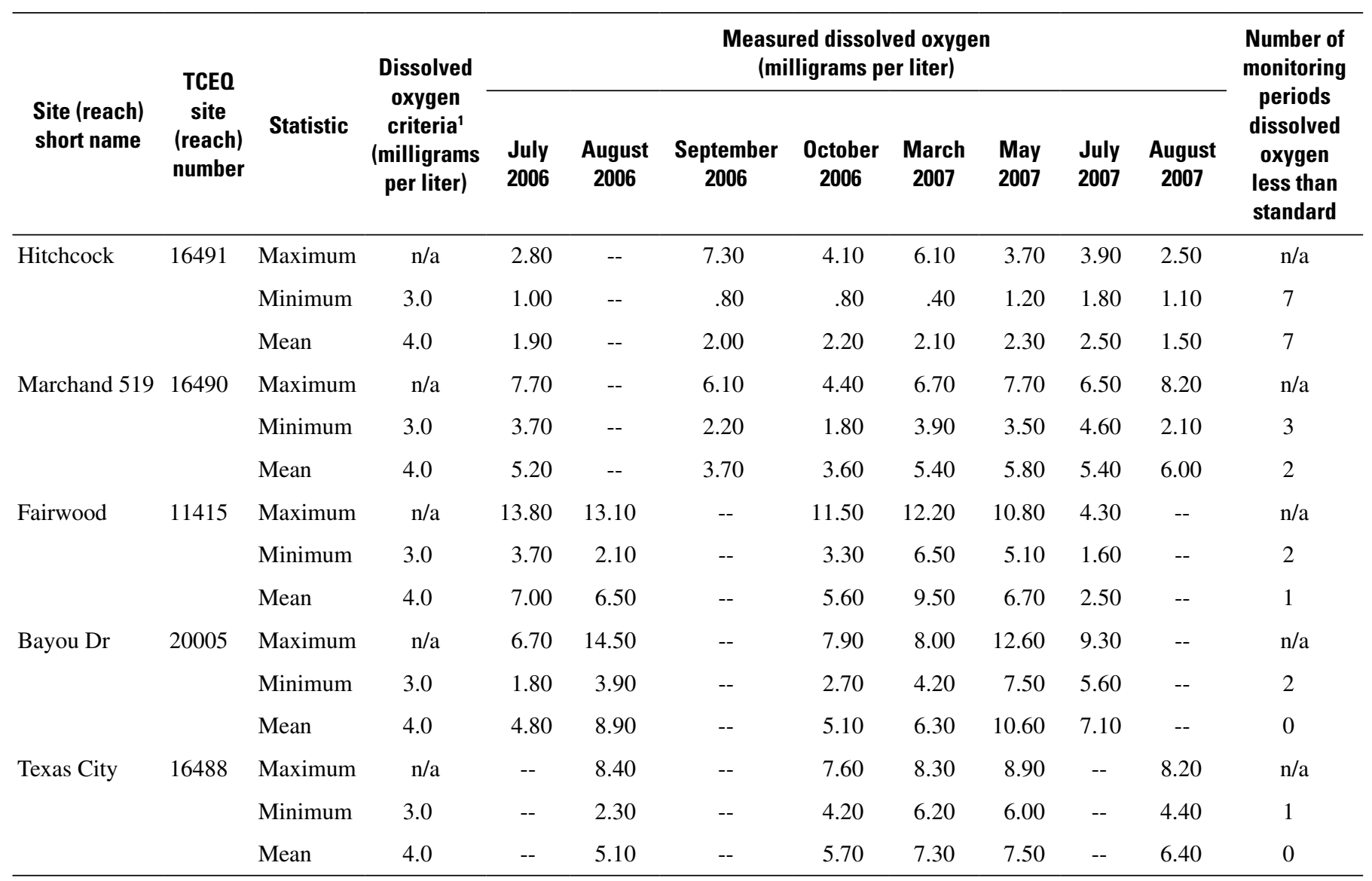

${ }^{1}$ Texas Commission on Environmental Quality, 2003a.

for this project in the Quality Assurance Project Plan as 20 percent, was calculated using the equation

$$
R P D=\left\{\left|\mathrm{S}_{1}-\mathrm{S}_{2}\right| /\left(\left[\mathrm{S}_{1}+\mathrm{S}_{2}\right] / 2\right)\right\} \times 100
$$

where

$\mathrm{S}_{1}=$ concentration from environmental sample; and

$\mathrm{S}_{2}=$ concentration from replicate sample.

The RPD exceeded 20 percent for six of 27 sample pairs of E. coli; the RPD did not exceed 20 percent for any sample pairs of chlorophyll- $a$, pheophytin- $a$, ammonia, or suspended sediment.

\section{Stream-Habitat Data}

The physical characteristics of a stream channel and the riparian characteristics can influence the structure and function of the benthic macroinvertebrate and fish communities (Stauffer and others, 2000; Brasher and others, 2003; Powers and others, 2003). Instream cover, which provides habitat for benthic macroinvertebrates and fish, consisted primarily of macrophytes, algae, and minor vegetation overhanging from the banks. Stream-habitat data collected at each site during the study are listed in appendix 4. Habitat quality index values indicated aquatic-life-use scores of "intermediate" at all five reaches except for a score of "high" at the Hitchcock site during August 2006 (table 6).

\section{Biological Data}

\section{Benthic Macroinvertebrates}

A total of 5,126 macroinvertebrate individuals from the five sites sampled were identified (appendix 5). The largest number of individuals $(1,069)$ was collected at the Texas City site in March 2007. The least number of individuals (9) was collected at the Hitchcock site in August 2006. Overall, 
A.

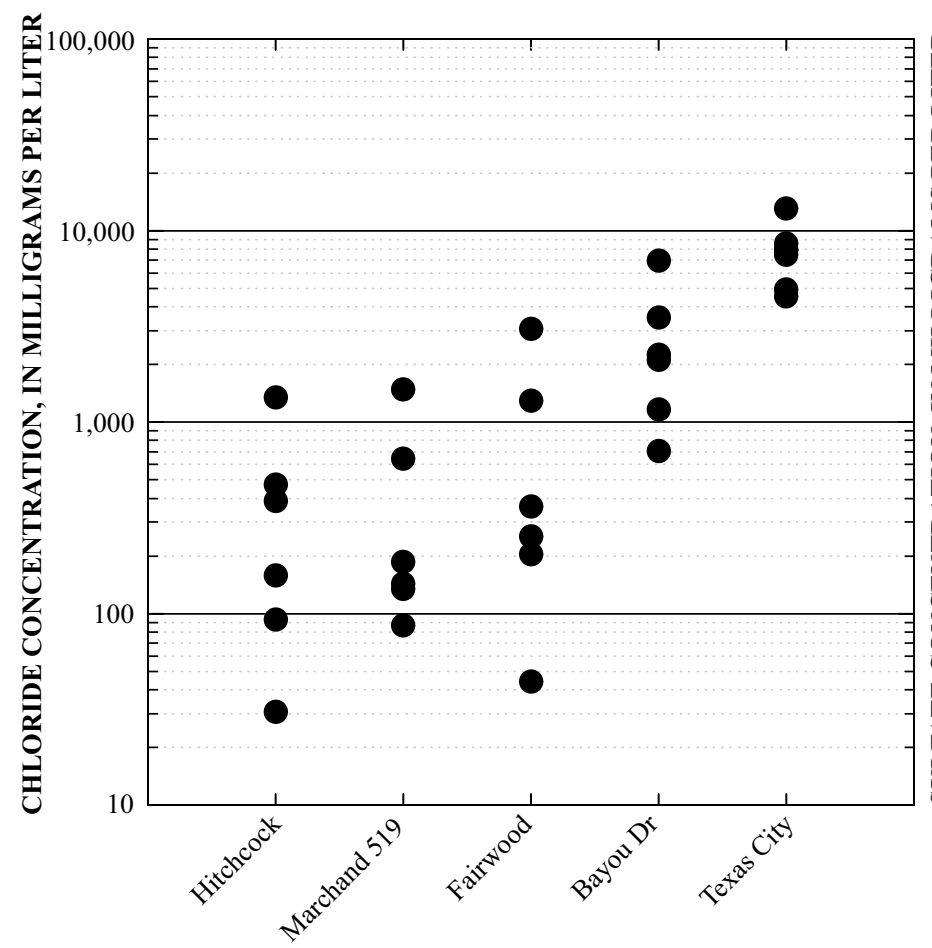

SITE SHORT NAME (table 1)
B.

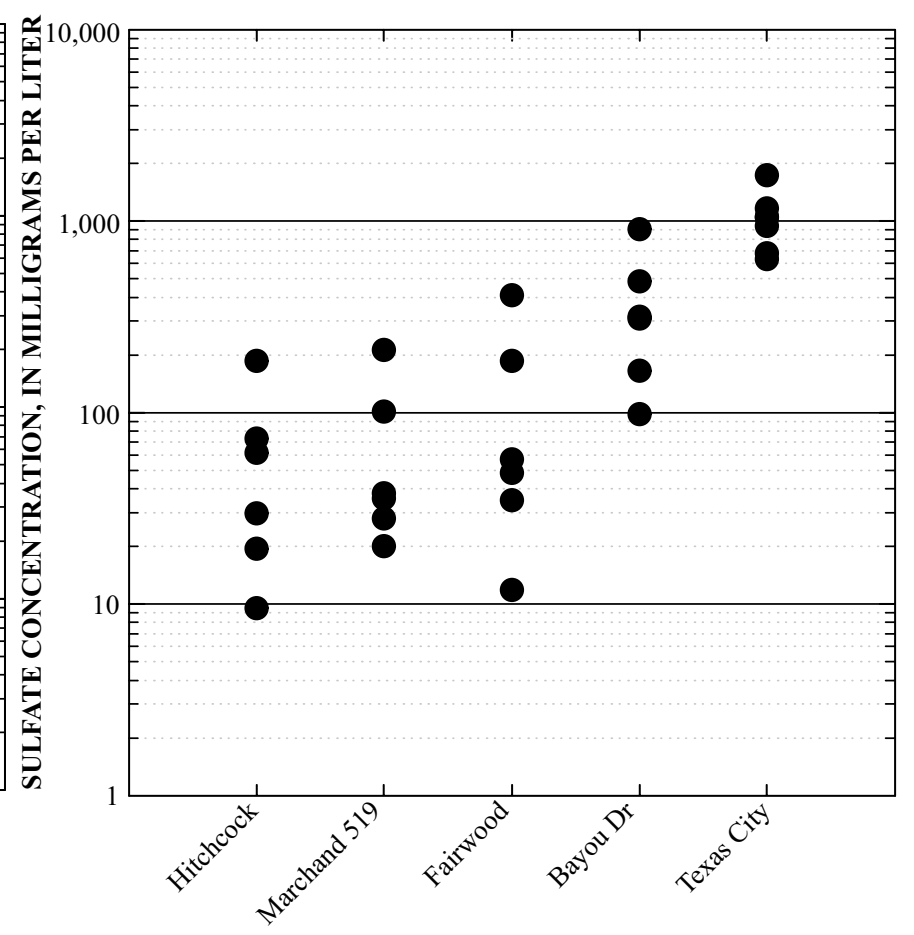

SITE SHORT NAME (table 1)

Figure 5. Distribution by site of $(A)$ chloride and (B) sulfate in samples from five sites (reaches), Highland and Marchand Bayous, Galveston County, Texas, 2006-07.

the most abundant macroinvertebrates belonged to the class Insecta, dominated by the Dipteran family Chironomidae, followed by marine segmented worms (class Polychaeta), Crustacea (class Malacostraca), bivalves (primarily the species Mytilopsis leucophaeata and Mulinia lateralis), and freshwater segmented worms (subclass Oligochaeta) (appendix 5).

The most abundant benthic invertebrate taxon overall was the chironomid genus Chironomus sp. (class Insecta), accounting for about 30 percent of all identified benthic macroinvertebrate taxa collected. The majority of Chironomus sp., however, were collected in the March 2007 samples; this taxon was either absent or substantially reduced in the August-July 2006 and August-July 2007 samples. Other relatively abundant taxa included the chironomid genus Tanypus sp., and the polychaete species Streblospio benedicti and Amphicteis floridus. The largest numbers for these species were again collected in the March 2007 samples.

The diversity and relative abundance of insect taxa (class Insecta) were generally larger in the more upstream sites (Hitchcock and Marchand 519), whereas Crustacea taxa (class Malacostraca), typical of more estuarine environments, generally had a larger relative abundance in the more downstream sites (Bayou Dr, and Texas City) (fig. 8). One exception to this general pattern was seen in March 2007 when large numbers of the relatively tolerant chironomid genus Chironomus sp. were collected at the Bayou Dr site. Marine segmented worms (class Polychaeta) were relatively ubiquitous and showed no general pattern across sites. The diversity and relative abundance of freshwater segmented worms (subclass Oligochaeta) were largest in the Marchand 519 and Fairwood sites.

Benthic macroinvertebrate assemblages were scored using indexes specified by the Texas Commission on Environmental Quality (2007). Aquatic-life-use scores (table 7) were "limited" during all surveys at the Hitchcock site, at the Fairwood site in July 2006, and at the Bayou Dr site in March 2007. Scores were "intermediate" during all surveys at the Marchand 519 and Texas City sites, at the Fairwood site in March and July 2007, and at the Bayou Dr site in July 2006 and July 2007.

The TCEQ aquatic-life-use assessment method was not specifically designed for tidally influenced systems such as Highland Bayou; some aspects of the assessment warrant further discussion.

Ephemeroptera, Plecoptera, and Tricoptera (EPT) taxa presence and abundance provide a measure of environmental quality in freshwater streams (Moring, 2003). EPT taxa were relatively abundant only at the Marchand 519 site and consisted of a single taxa (the relatively tolerant genus Caenis sp.). Plecoptera, which are adapted to cool water conditions, are not generally found in coastal systems and were not collected at any of the sites. Six individuals of the Tricopteran species Hydroptila potosina were collected at the Bayou 
A.

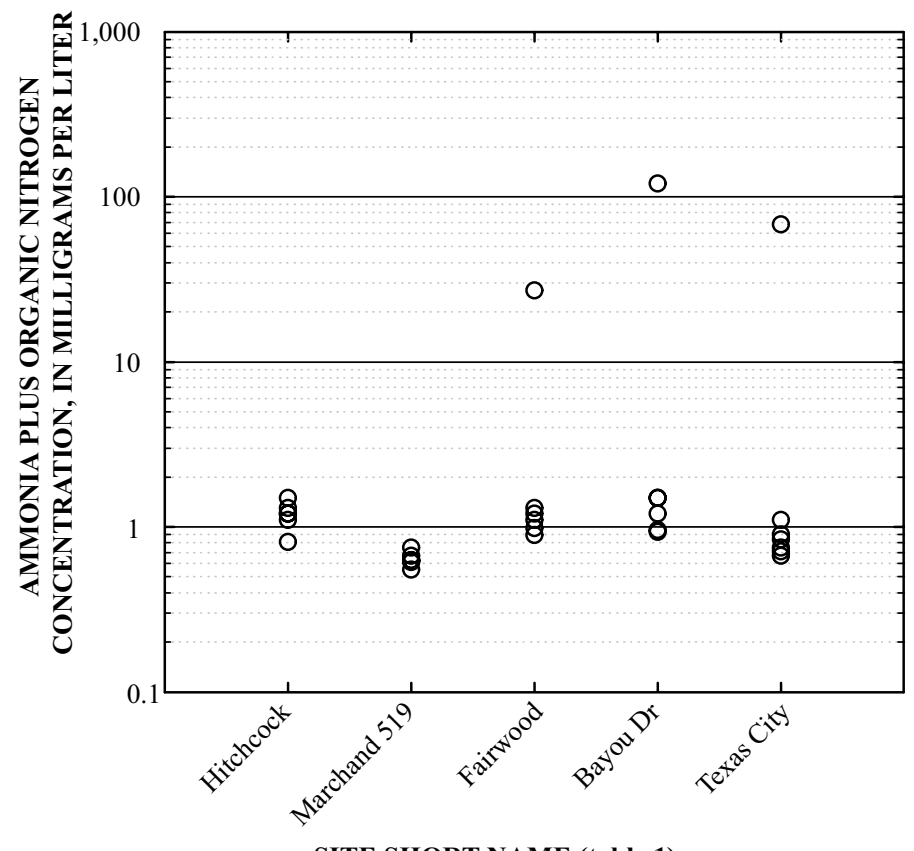

C.

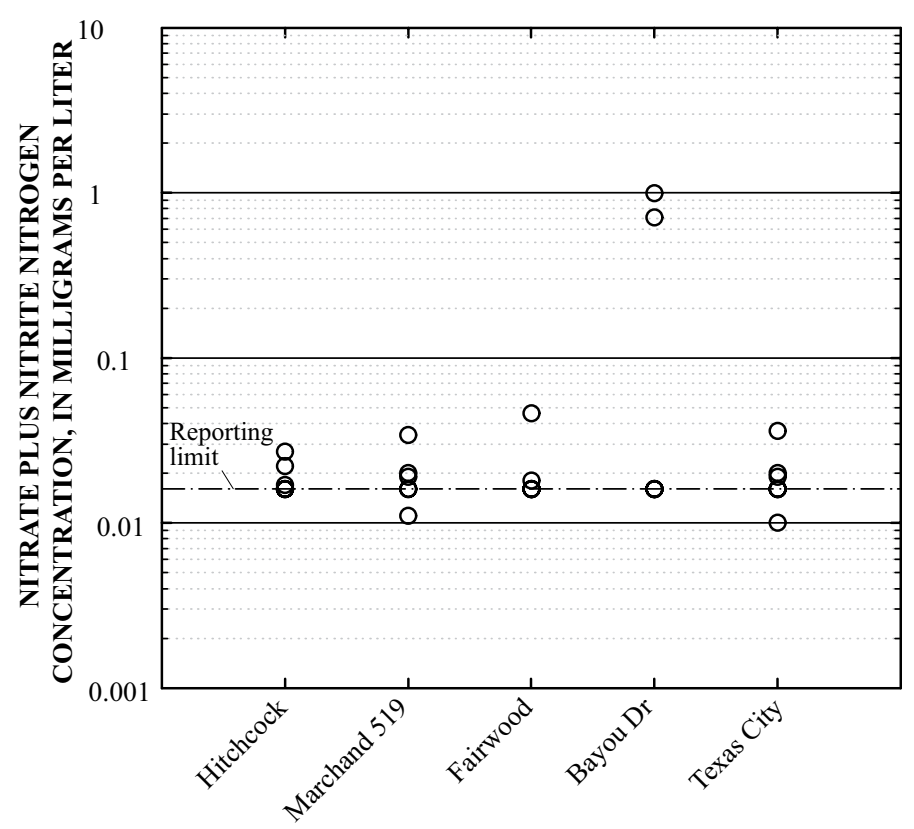

SITE SHORT NAME (table 1)
B.

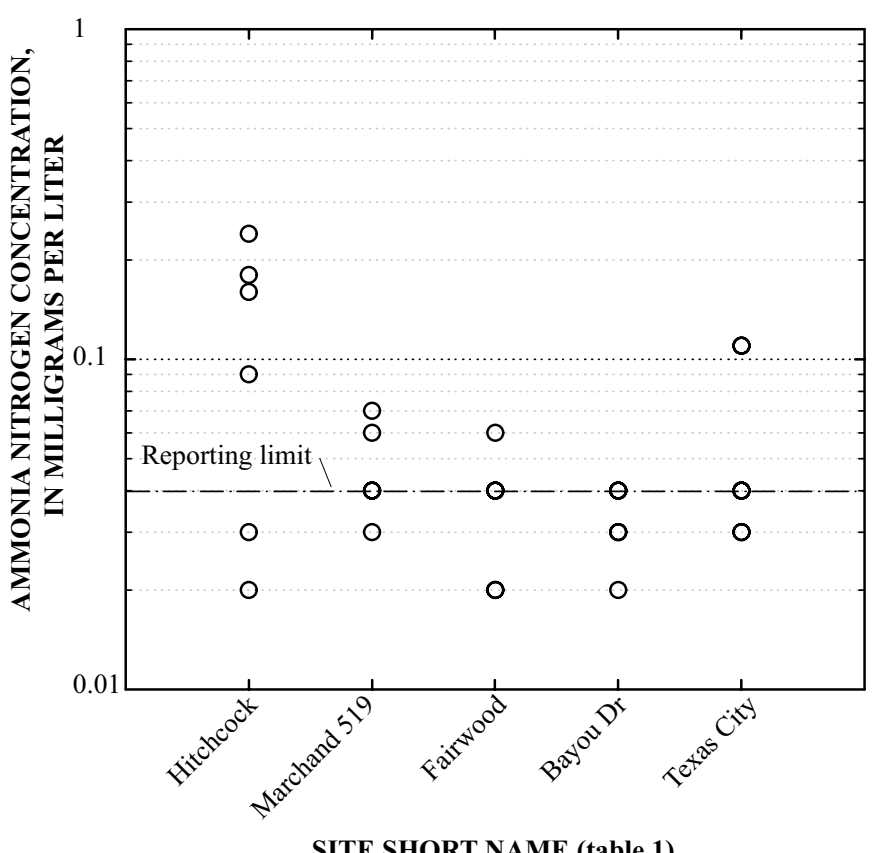

D.

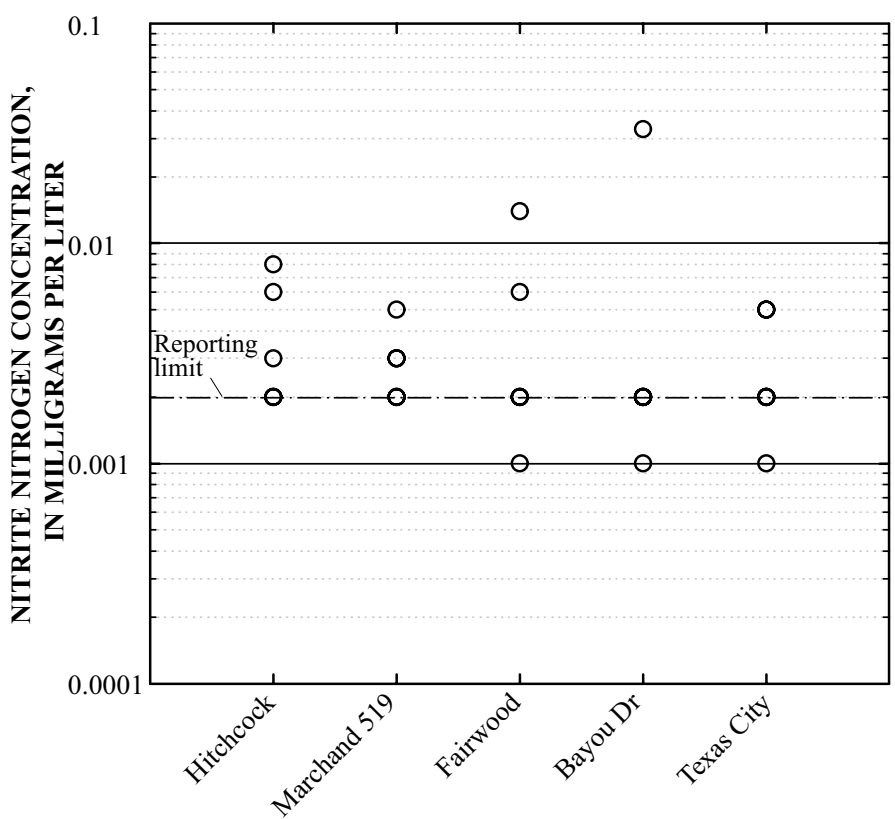

SITE SHORT NAME (table 1)

Figure 6. Distribution by site of $(A)$ ammonia plus organic nitrogen, $(B)$ ammonia nitrogen, $(C)$ nitrate plus nitrite nitrogen, (D) nitrite nitrogen, (E) orthophosphate phosphorus, and (F) total phosphorus in samples from five sites (reaches), Highland and Marchand Bayous, Galveston County, Texas, 2006-07. 
E.

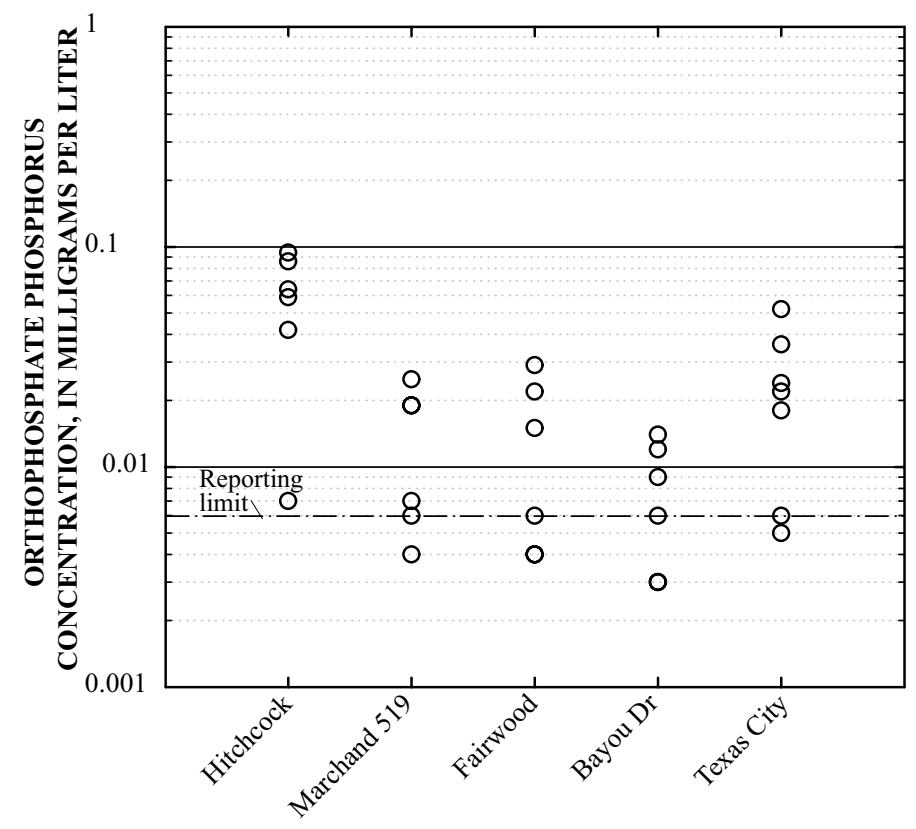

SITE SHORT NAME (table 1)
F.

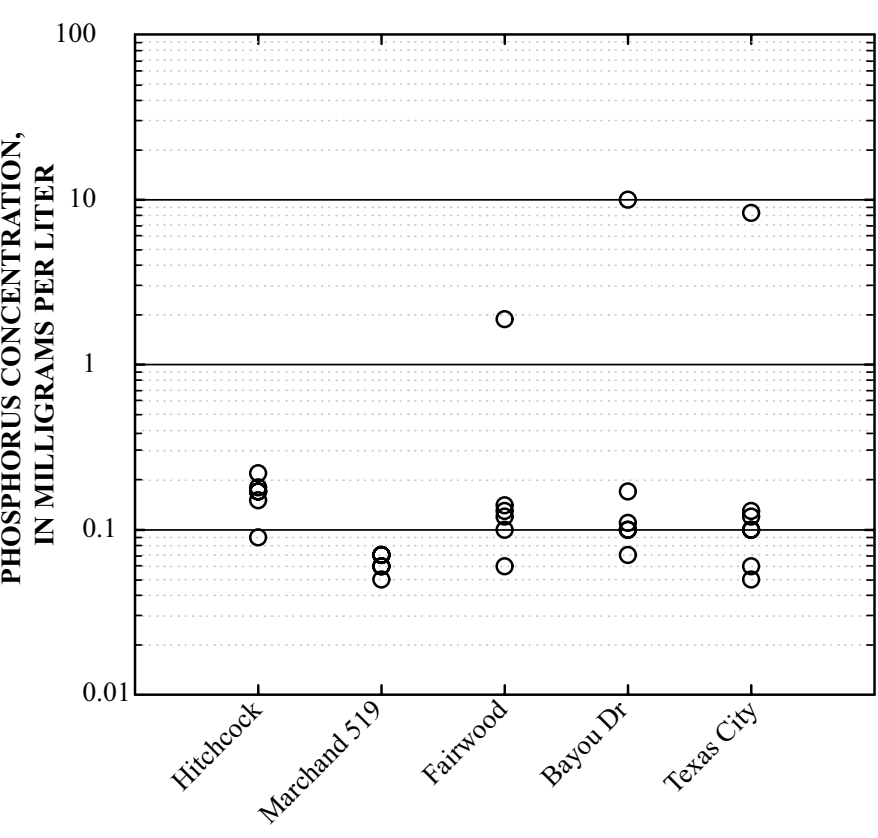

SITE SHORT NAME (table 1)

Figure 6.-Continued.

Dr reach in July 2006. However, this species is not typical of mud-bottom estuarine systems and may represent an incidental species washed down from a more freshwater location upstream.

Benthic macroinvertebrate communities were compared by computing the Hilsenhoff biotic index (HBI) (Hilsenhoff, 1988). The HBI assigns a tolerance value to individual taxa and then calculates an overall tolerance value for the community. Individual tolerance values are measured on a scale from 0 to 10 with increasing tolerance values indicating increasing tolerance to physiochemical degradation.

This index is computed using the equation

$$
\mathrm{HBI}=\frac{\left[\left(\mathrm{TV}_{\mathrm{i}}\right)\left(\mathrm{n}_{\mathrm{i}}\right)\right]}{\mathrm{N}}
$$

where

$\mathrm{TV}_{\mathrm{i}}=$ tolerance value for each species;

$\mathrm{n}_{\mathrm{i}}=$ number of individuals in the species; and,

$\mathrm{N}=$ total number of individuals in the collection.

HBIs ranged from 6.00 at site Hitchcock to 10.0 at sites Texas City, Hitchcock, and Bayou Dr.

In freshwater streams HBI values are inversely related to stream quality (taxa/species with lower values indicate the presence of higher stream quality). However, because HBI calculations include only taxa that have assigned tolerance values and because the TCEQ tolerance values were developed for freshwater systems, few of the estuarine adapted taxa have available tolerance values. In addition, the freshwater taxa in tidally influenced systems are generally the more tolerant freshwater taxa. Therefore HBI scores for Highland Bayou (1 at all sites, table 7) might reflect a lack of available tolerance values for estuarine adapted taxa and not necessarily relatively poor water quality compared to other estuarine systems.

Vannote and others (1980) proposed that the types of macroinvertebrate communities in rivers form a continuum from the headwaters to the mouth and correlate with the sources of nutrition in the rivers. Smaller streams of the headwaters would be dominated by macroinvertebrates that are capable of using coarser vegetation (shredders and scrapers); macroinvertebrates that could use finer organic particulate matter (filterers and gatherers) would increase in number downstream. The relative abundance of benthic macroinvertebrate functional feeding groups in Highland Bayou is dominated by collectors and predators (table 7) with relatively fewer filterers and grazers. However, a large percentage of the taxa at most sites have not been formally classified and are categorized as unknown. Several of the taxa commonly found in this study such as the tube dwelling polychaete worms Amphicteis floridus and Streblospio benedicti are known to be collectors that feed on detritus (Fauchald and Jumars, 1979), whereas others such as the polychaete genera Polydora are considered to be partially or wholly filter feeders (Fauchald and Jumars, 1979). A more complete classification of estuarine benthic macroinvertebrates in terms of feeding methods would likely increase the relative percentage of collectors and filterers at these sites. 
A.

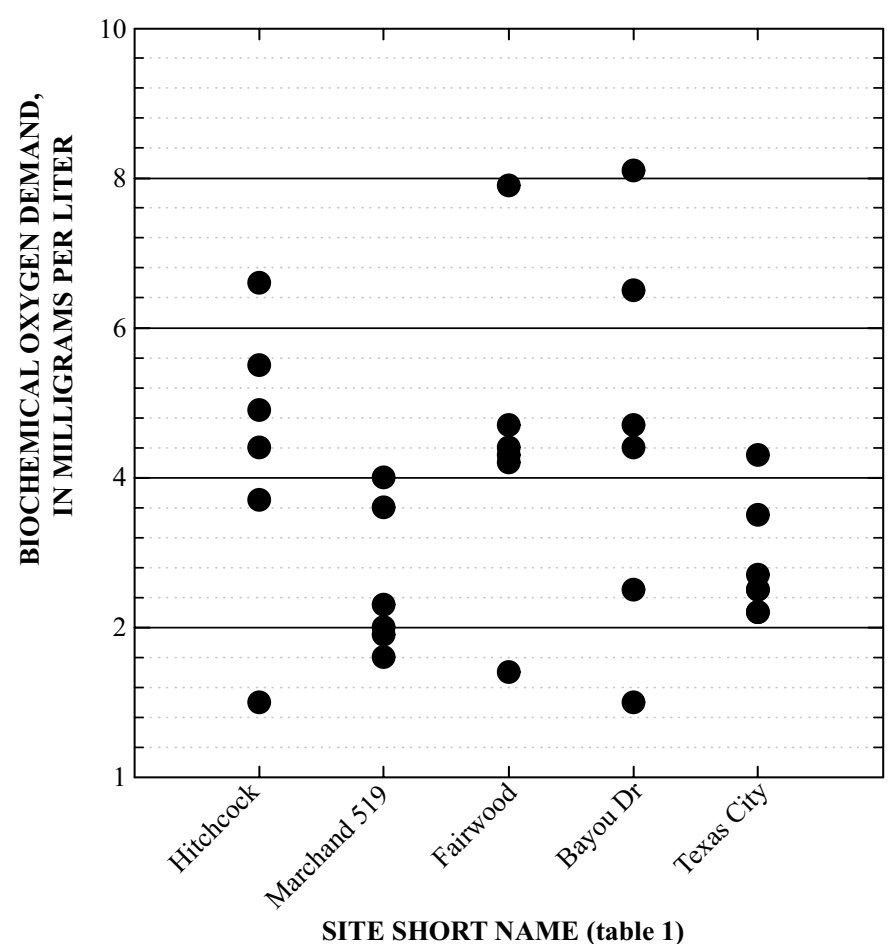

C.

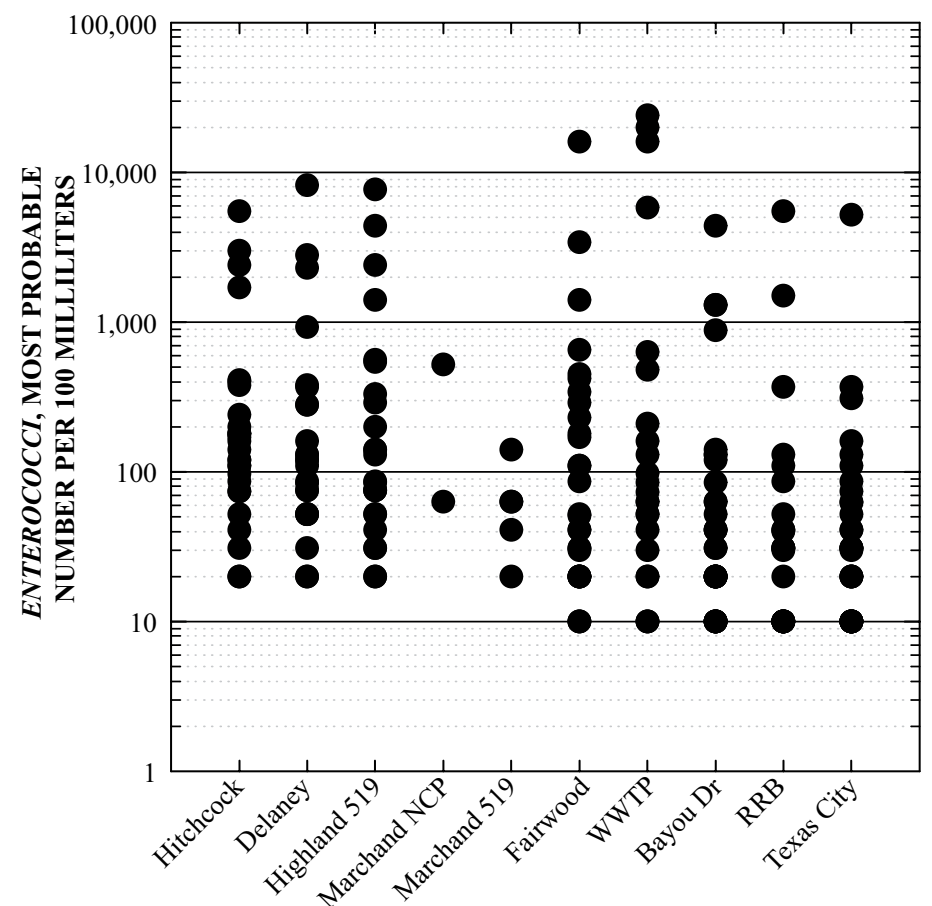

SITE SHORT NAME (table 1)
B.

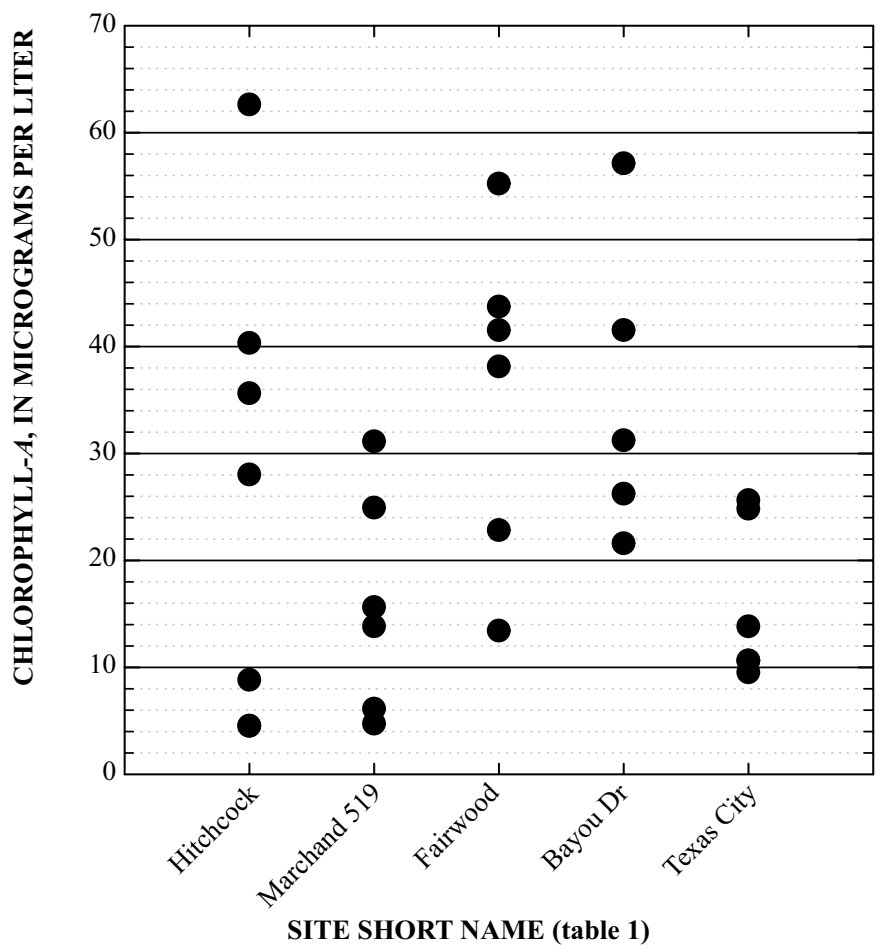

D.

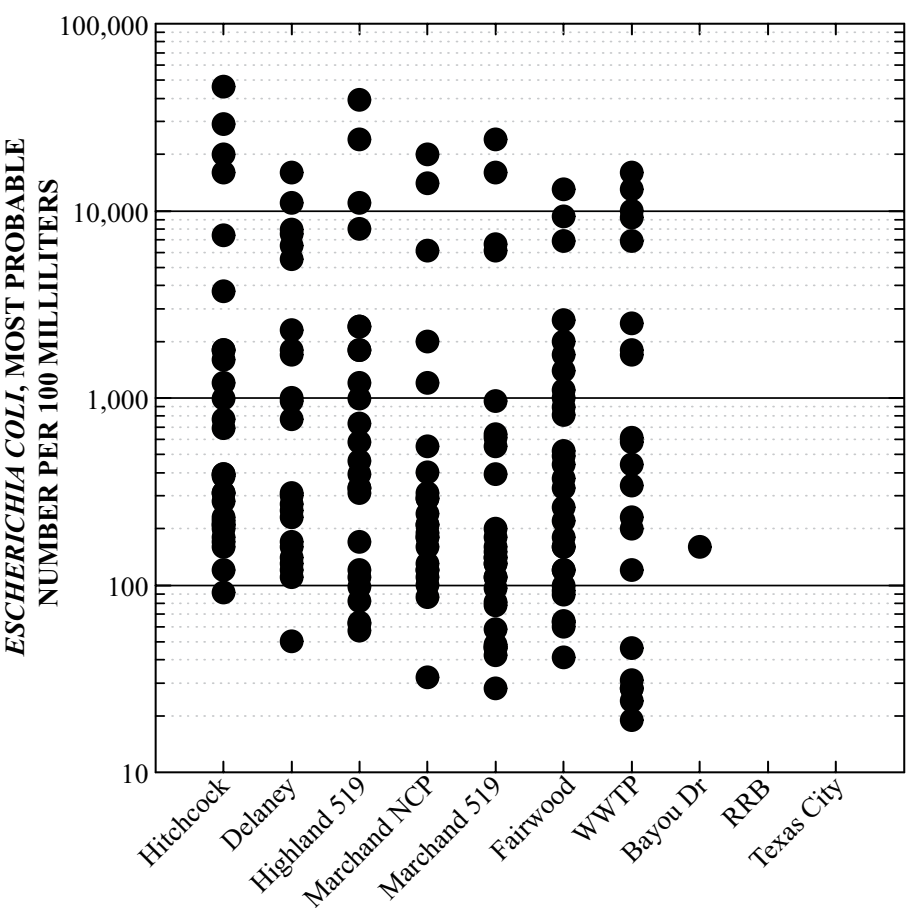

SITE SHORT NAME (table 1)

Figure 7. Distribution by site of (A) biochemical oxygen demand and (B) chlorophyll-a in samples from five sites (reaches); (C) Enterococci and (D) Escherichia coli in samples from 10 sites (reaches), Highland and Marchand Bayous, Galveston County, Texas, 2006-07. 
Table 6. Scores for stream-habitat metrics and habitat quality index for representative reach at each of five sites, Highland and Marchand Bayous, Galveston County, Texas, 2006-07.

\begin{tabular}{|c|c|c|c|c|c|c|c|c|c|c|c|c|c|c|c|}
\hline \multirow{2}{*}{$\begin{array}{l}\text { Stream-habitat } \\
\text { metric }\end{array}$} & \multicolumn{3}{|c|}{ Hitchcock } & \multicolumn{3}{|c|}{ Marchand 519} & \multicolumn{3}{|c|}{ Fairwood } & \multicolumn{3}{|c|}{ Bayou Dr } & \multicolumn{3}{|c|}{ Texas City } \\
\hline & $\begin{array}{c}\text { August } \\
2006\end{array}$ & $\begin{array}{c}\text { March } \\
2007\end{array}$ & $\begin{array}{l}\text { July } \\
2007\end{array}$ & $\begin{array}{l}\text { July } \\
2006\end{array}$ & $\begin{array}{c}\text { March } \\
2007\end{array}$ & $\begin{array}{c}\text { August } \\
2007\end{array}$ & $\begin{array}{l}\text { July } \\
2006\end{array}$ & $\begin{array}{c}\text { March } \\
2007\end{array}$ & $\begin{array}{l}\text { July } \\
2007\end{array}$ & $\begin{array}{l}\text { July } \\
2006\end{array}$ & $\begin{array}{c}\text { March } \\
2007\end{array}$ & $\begin{array}{l}\text { July } \\
2007\end{array}$ & $\begin{array}{l}\text { July } \\
2006\end{array}$ & $\begin{array}{c}\text { March } \\
2007\end{array}$ & $\begin{array}{c}\text { August } \\
2007\end{array}$ \\
\hline Riffles & 1 & 1 & 1 & 1 & 1 & 1 & 1 & 1 & 1 & 1 & 1 & 1 & 1 & 1 & 1 \\
\hline Pools & 1 & 1 & 1 & 1 & 1 & 1 & 1 & 1 & 1 & 1 & 1 & 1 & 1 & 1 & 1 \\
\hline \multicolumn{16}{|l|}{ Bank stability: } \\
\hline Erosion component & 3 & 2 & 2 & 2 & 2 & 2 & 2 & 2 & 2 & 3 & 3 & 3 & 2 & 2 & 2 \\
\hline Riparian buffer vegetation & 3 & 3 & 3 & 3 & 3 & 3 & 3 & 3 & 3 & 3 & 3 & 3 & 2 & 2 & 2 \\
\hline Channel flow status & 3 & 3 & 3 & 2 & 2 & 2 & 3 & 3 & 3 & 3 & 3 & 3 & 3 & 3 & 3 \\
\hline Channel sinuosity & 3 & 3 & 3 & 1 & 1 & 1 & 1 & 1 & 1 & 2 & 2 & 2 & 0 & 0 & 0 \\
\hline Bottom substrate & 1 & 1 & 1 & 1 & 1 & 1 & 1 & 1 & 1 & 1 & 1 & 1 & 1 & 1 & 1 \\
\hline Aquatic-life-use category $^{1}$ & $\mathrm{H}$ & $\mathrm{I}$ & $\mathrm{I}$ & $\mathrm{I}$ & $\mathrm{I}$ & $\mathrm{I}$ & $\mathrm{I}$ & $\mathrm{I}$ & $\mathrm{I}$ & $\mathrm{I}$ & $\mathrm{I}$ & $\mathrm{I}$ & $\mathrm{I}$ & $\mathrm{I}$ & $\mathrm{I}$ \\
\hline
\end{tabular}

${ }^{1}$ Texas Commission on Environmental Quality (2007); H, high (20-25); I, intermediate (14-19).

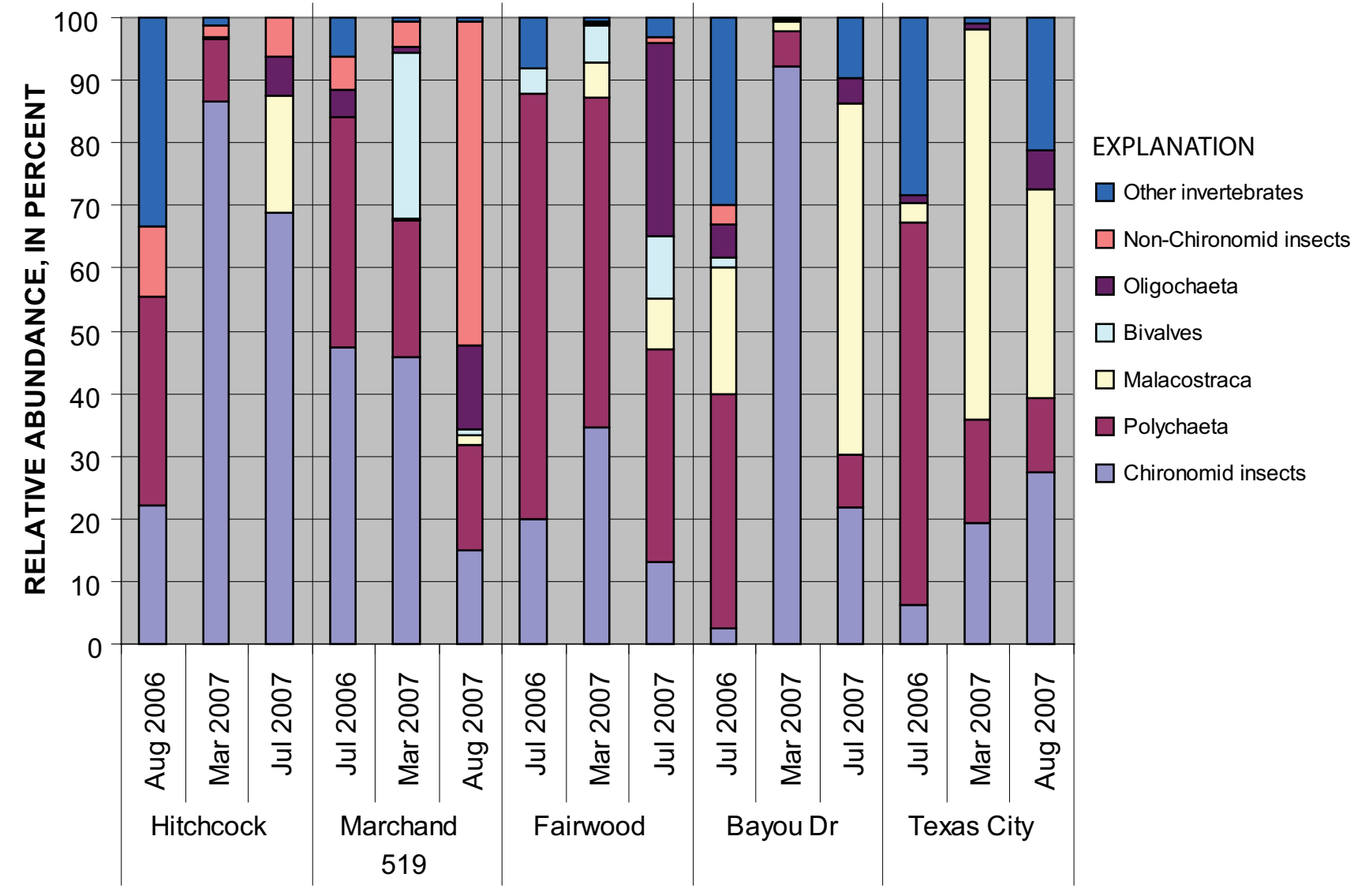

\section{SITE SHORT NAME (table 1) AND DATE}

Figure 8. Relative abundance of benthic macroinvertebrates for representative reach at each of five sites, Highland and Marchand Bayous, Galveston County, Texas, 2006-07 
Table 7. Scores for benthic macroinvertebrate metrics and aquatic life use for representative reach at each of five sites, Highland and Marchand Bayous, Galveston County, Texas, 2006-07.

[EPT, Epheroptera, Plecoptera, Trichoptera]

\begin{tabular}{|c|c|c|c|c|c|c|c|c|c|c|c|c|c|c|c|}
\hline \multirow[b]{2}{*}{$\begin{array}{l}\text { Benthic macroinvertebrate } \\
\text { metric }\end{array}$} & \multicolumn{3}{|c|}{ Hitchcock } & \multicolumn{3}{|c|}{ Marchand 519} & \multicolumn{3}{|c|}{ Fairwood } & \multicolumn{3}{|c|}{ Bayou Dr } & \multicolumn{3}{|c|}{ Texas City } \\
\hline & $\begin{array}{c}\text { August } \\
2006\end{array}$ & $\begin{array}{c}\text { March } \\
2007\end{array}$ & $\begin{array}{l}\text { July } \\
2007\end{array}$ & $\begin{array}{l}\text { July } \\
2006\end{array}$ & $\begin{array}{c}\text { March } \\
2007\end{array}$ & $\begin{array}{c}\text { August } \\
2007\end{array}$ & $\begin{array}{l}\text { July } \\
2006\end{array}$ & $\begin{array}{c}\text { March } \\
2007\end{array}$ & $\begin{array}{l}\text { July } \\
2007\end{array}$ & $\begin{array}{l}\text { July } \\
2006\end{array}$ & $\begin{array}{c}\text { March } \\
2007\end{array}$ & $\begin{array}{l}\text { July } \\
2007\end{array}$ & $\begin{array}{l}\text { July } \\
2006\end{array}$ & $\begin{array}{c}\text { March } \\
2007\end{array}$ & $\begin{array}{c}\text { August } \\
2007\end{array}$ \\
\hline EPT taxa abundance & 1 & 1 & 1 & 1 & 1 & 1 & 1 & 1 & 1 & 1 & 1 & 1 & 1 & 1 & 1 \\
\hline Hilsenhoff biotic index (HBI) & 1 & 1 & 1 & 1 & 1 & 1 & 1 & 1 & 1 & 1 & 1 & 1 & 1 & 1 & 1 \\
\hline $\begin{array}{l}\text { Percentage dominant functional } \\
\text { feeding group }\end{array}$ & 4 & 1 & 1 & 4 & 3 & 4 & 4 & 4 & 4 & 4 & 1 & 4 & 4 & 4 & 4 \\
\hline Percentage predators & 2 & 4 & 1 & 4 & 4 & 3 & 4 & 1 & 1 & 1 & 2 & 1 & 4 & 3 & 2 \\
\hline $\begin{array}{l}\text { Ratio of intolerant to tolerant } \\
\text { taxa }\end{array}$ & 1 & 1 & 4 & 1 & 1 & 1 & 1 & 1 & 1 & 1 & 1 & 1 & 1 & 1 & 1 \\
\hline $\begin{array}{l}\text { Percentage of total number as } \\
\text { Elmidae }\end{array}$ & 1 & 1 & 1 & 1 & 1 & 1 & 1 & 1 & 1 & 1 & 1 & 1 & 1 & 1 & 1 \\
\hline Percentage Chironomidae & 1 & 1 & 1 & 1 & 1 & 2 & 1 & 1 & 2 & 4 & 1 & 1 & 3 & 1 & 1 \\
\hline Percentage collector-gatherers & 1 & 1 & 1 & 3 & 2 & 3 & 1 & 2 & 1 & 1 & 1 & 1 & 1 & 1 & 1 \\
\hline Total score & 18 & 21 & 17 & 27 & 26 & 28 & 20 & 24 & 22 & 28 & 17 & 23 & 25 & 22 & 22 \\
\hline Aquatic life use ${ }^{1}$ & $\mathrm{~L}$ & $\mathrm{~L}$ & $\mathrm{~L}$ & I & I & I & $\mathrm{L}$ & I & I & I & $\mathrm{L}$ & I & I & I & I \\
\hline
\end{tabular}

${ }^{1}$ Texas Commission on Environmental Quality (2007); L, limited (less than 22); I, intermediate (22-28).

\section{Fish}

Thirty-four species of fish representing 28 families were collected from Highland and Marchand Bayous. Fish taxa and individual counts from each survey are listed in appendix 6. A total of 6,057 fish were collected. Juveniles of the genus Brevoortia sp. were the most abundant taxa; other abundant taxa included Menidia beryllina, Leiostomus xanthurus, Anchoa mitchilli, Mugil cephalus, and Lagodon rhomboides.

Fish communities were scored using a regional index designed for the Western Gulf Coastal Plain (Texas Commission on Environmental Quality, 2007). Aquatic-life-use scores (table 8) were "limited" during all surveys at the Fairwood, Bayou Dr, and Texas City sites; at the Hitchcock site in August 2006; and at the Marchand 519 site in March 2007. Fish communities were scored as "intermediate" at the Hitchcock site in March and July 2007 and at the Marchand 519 site in July 2006 and August 2007.

The presence and relative abundance of tolerant and intolerant fish reflect stream conditions. Intolerant fish species indicate high and moderate quality sites (Linam and Kleinsasser, 1998) and become increasingly scarce with pollution or destruction of suitable habitat. Tolerant fish species have increased distribution and abundance when site conditions are less favorable and become dominant in disturbed sites. Of the 34 fish species collected in Highland Bayou, nine were identified as having a specific tolerance or intolerance to pollution (Linam and Kleinsasser, 1998). Eight of the species were identified as tolerant (appendix 6) - sheepshead minnow (Cyprinodon variegatus); western mosquitofish (Gambusi affinis); sunfish (Lepomis macrochirus, Lepomis cyanellus, Lepomis gulosus); sailfin molly (Poecilia latipinna); gar (Lepisosteus oculatus), and gizzard shad (Dorosoma cepedianum). One species, spotted seatrout (Cynoscion nebulosus), was identified as being intolerant to pollution. However, western mosquitofish are common to most waters in Texas and are not used when calculating values for tolerance indexes (Texas Commission on Environmental Quality, 2007).

Tolerant species constituted only a small part of the overall fish communities (table 9) at the downstream sites (Bayou Dr and Texas City) and the most upstream site (Hitchock). The largest values for relative abundance of tolerant species 
Table 8. Scores for fish metrics and index of biotic integrity for representative reach at each of five sites, Highland and Marchand Bayous, Galveston County, Texas, 2006-07.

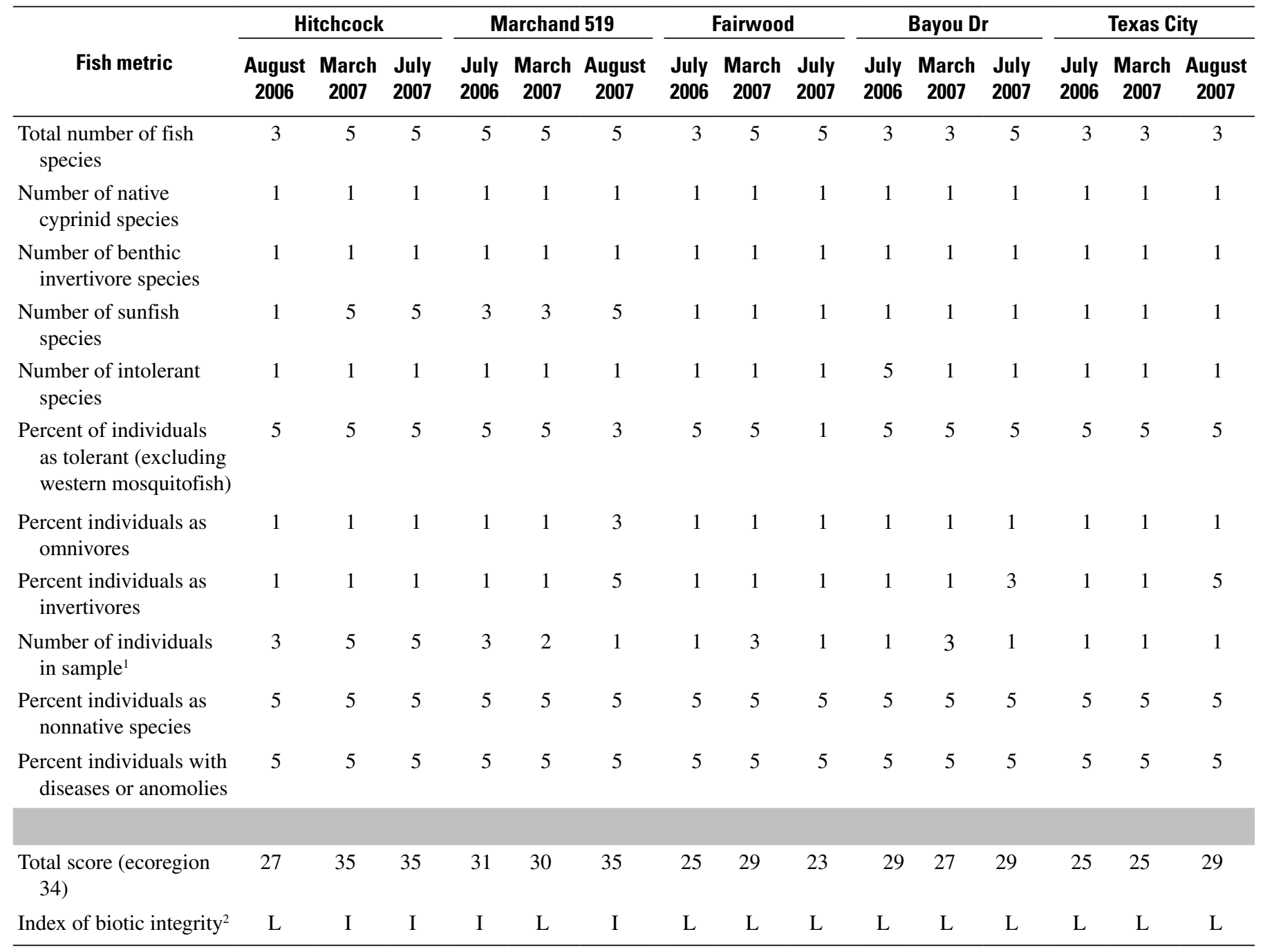

\footnotetext{
${ }^{1}$ Average of number of individuals per seine haul and number of individuals per electrofishing minute.

${ }^{2}$ Linam and others (2002); Texas Commission on Environmental Quality (2007); L, limited aquatic life use (less than 31); I, intermediate aquatic life use $(31-38)$.
}

Table 9. Relative abundance of tolerant fish species, excluding western mosquitofish, for representative reach at each of five sites, Highland and Marchand Bayous, Galveston County, Texas, 2006-07.

\begin{tabular}{|c|c|c|c|c|c|}
\hline $\begin{array}{l}\text { Site short } \\
\text { name }\end{array}$ & \multicolumn{5}{|c|}{ Sampling date } \\
\hline Marchand 519 & 5.3 & -- & 26.5 & -- & 37.5 \\
\hline Fairwood & 2.6 & -- & 4.1 & 57.1 & -- \\
\hline Texas City & 0 & -- & .4 & -- & 0 \\
\hline
\end{tabular}


Table 10. Average aquatic-life-use category indicated by stream habitat, benthic macroinvertebrates, and fish for representative reach at each of five sites, Highland and Marchand Bayous, Galveston County, Texas, 2006-07.

[I, intermediate; L, limited]

\begin{tabular}{lccccc}
\hline \multirow{2}{*}{$\begin{array}{c}\text { Category } \\
\text { indicator }\end{array}$} & \multicolumn{3}{c}{ Average aquatic life use } \\
\cline { 2 - 5 } & Hitchock & Marchand 519 & Fairwood & Bayou Dr & Texas City \\
\hline Stream habitat $^{1}$ & I & I & I & I \\
Benthic macroinvertebrates & & L & I & I & I \\
Fish $^{3}$ & I & I & L & L \\
\hline
\end{tabular}

\footnotetext{
${ }^{1}$ Habitat quality index aquatic-life-use scores (Texas Commission on Environmental Quality, 2007).

${ }^{2}$ Benthic macroinvertebrate aquatic-life-use scores (Texas Commission on Environmental Quality, 2007).

${ }^{3}$ Index of biotic integrity aquatic-life-use scores for ecoregion 34 (Linam and others, 2002; Texas Commission on Environmental Quality, 2007).
}

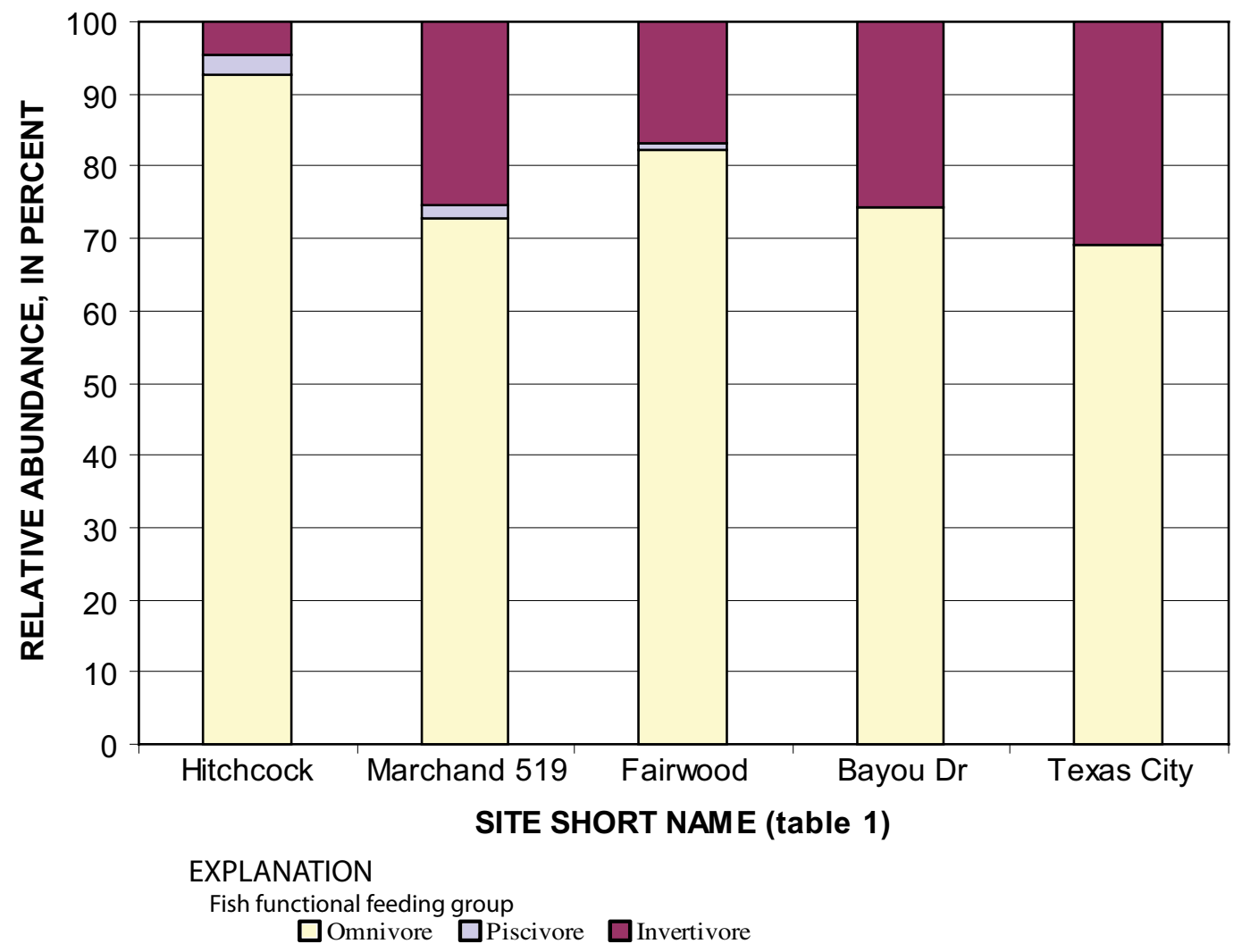

Figure 9. Relative abundance of fish functional feeding groups for representative reach at each of five sites, Highland and Marchand Bayous, Galveston County, Texas, 2006-07.

occurred in the summer sampling when tolerant freshwater sunfish composed a large part of the catch at the Marchand 519 site and tolerant euryhaline pupfishes and livebearers composed a majority of the catch at the Fairwood site.

However, as with the benthic macroinvertebrates, most of the estuarine species collected in Highland Bayou do not have assigned tolerance values and freshwater species found in tidally influenced systems are generally more tolerant. High tolerance values in Highland Bayou may reflect the dynamic physiochemical environment common to tidally influenced systems and not necessarily poor water quality.

Fish species can be separated into trophic groups, which describe the manner in which they feed. There are three trophic (feeding) groups (fig. 9): omnivores (generalized feeders); invertivores (feed on invertebrates, mostly insects); and piscivores (feed on other fish). The majority of fish collected 


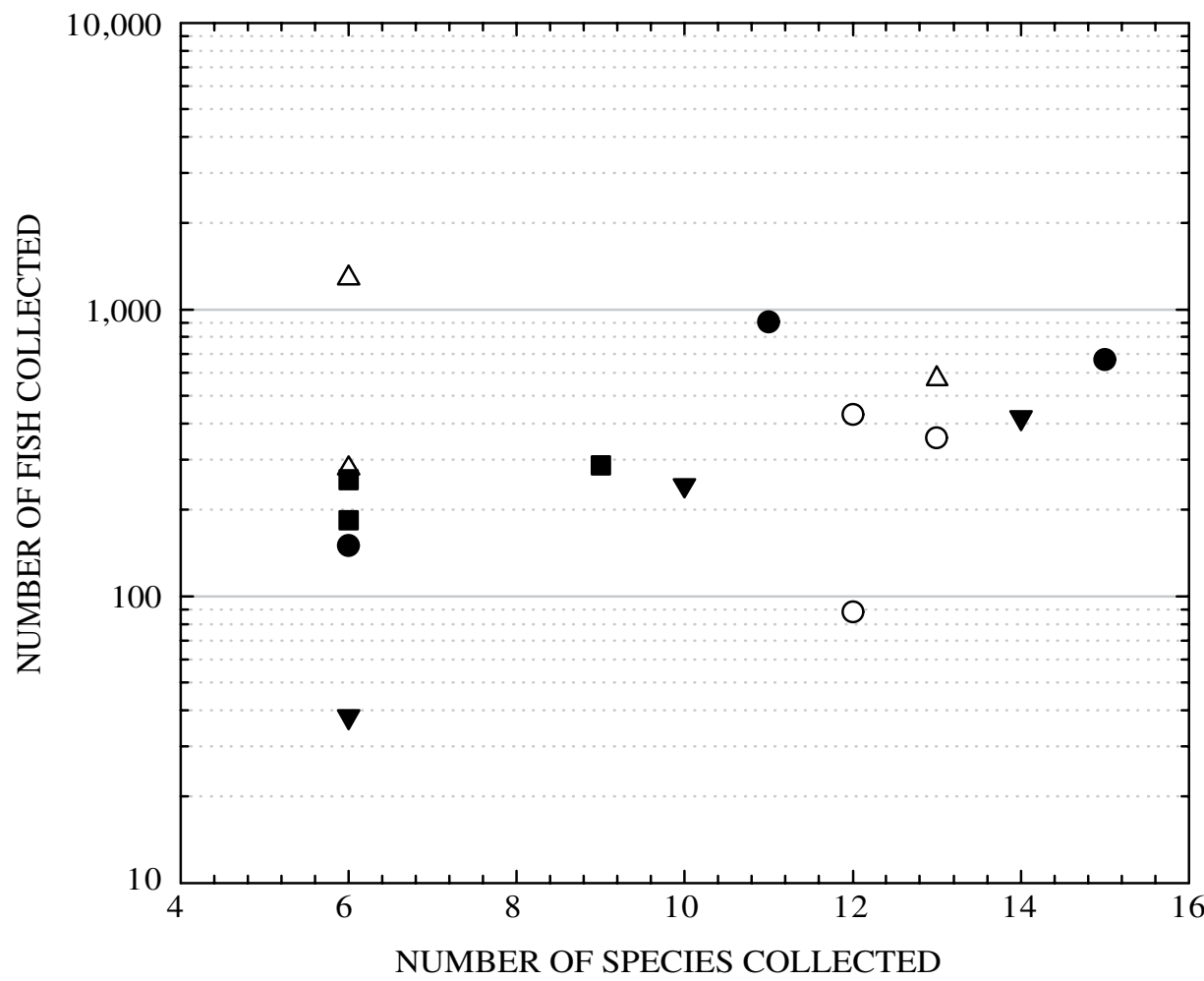

\author{
EXPLANATION \\ SITE SHORT NAME (TABLE 1) \\ - Hitchcock \\ O Marchand 519 \\ $\nabla$ Fairwood \\ $\triangle$ Bayou Dr \\ - Texas City
}

Figure 10. Number of fish collected relative to number of fish species from representative reach at each of five sites, Highland and Marchand Bayous, Galveston County, Texas, 2006-07.

at the five sites were omnivores and the next most abundant were invertivores. Trophic composition metrics may help to evaluate the quality of the stream habitat and chemical quality in that more generalized feeders, such as omnivores, become a larger percentage of the population with degradation of conditions (Linam and Kleinsasser, 1998).

The distribution of the total number of fish collected relative to the number of species from each site is shown in figure 10. If the number of species is proportional to the number of individuals collected (high sampling efficiency), a graph of data for the sites would have a linear relation. Departures from a linear relation between the number of fish and species can reflect several factors, including sampling efficiency (bias), seasonality, and local site conditions.

The average aquatic-life-use category indicated by stream-habitat, macroinvertebrate, and fish data collected between July 2006 and September 2007 are presented in table 10 . The average aquatic-life-use category for stream habitat was "intermediate" at all sites. Aquatic life use based on macroinvertebrate data was "limited" at the Hitchcock site and "intermediate" at the remaining sites. Average aquatic life use based on the index of biotic integrity for fish was "limited" at the Fairwood, Bayou Dr, and Texas City sites and "intermediate" at the remaining sites.

\section{Summary}

The Texas Commission on Environmental Quality (TCEQ) administers water-quality management programs with the goal of protecting, maintaining, and restoring water resources in Texas. One such program is the Texas Clean Rivers Program (CRP), which was established by the 1991 Texas Legislature. Under the CRP, water-quality monitoring and assessments are conducted in 23 river and coastal basins statewide through contracts with partner agencies. The Houston-Galveston Area Council (H-GAC) is the partner agency for a 13-county area in southeastern Texas that includes the Houston metropolitan area. Every 2 years, CRP partners may perform systematic monitoring studies, whereby a variety of data are collected in water bodies that are not monitored routinely. Data from these special studies help to determine whether additional assessment is needed to evaluate human health concerns, the status of ecological conditions, or designated stream uses.

The coastal basins of Highland and Marchand Bayous in Galveston County were chosen for this monitoring study. Both bayous currently (2008) are listed on the 303(d) list of impaired waters in Texas for low dissolved oxygen. Parts of Highland Bayou and all of Marchand Bayou also are listed as 
impaired because of high bacteria concentrations. The U.S. Geological Survey, in cooperation with H-GAC and TCEQ, collected data during 2006-07 to document water-quality, stream-habitat, and biological conditions in the bayous.

This report presents the water-quality, stream-habitat, and biological data collected from Highland and Marchand Bayous; describes data-collection methods; and presents data to compare water-quality changes at and among sites during the study period.

Data for this report were collected at 10 sites (reaches) in the Highland and Marchand Bayous watershed. Water-quality data collected include continuously monitored data-properties measured with a multiprobe instrument at each site and water sampling data-properties and constituents determined from periodically collected samples.

Four properties (water temperature, $\mathrm{pH}$, specific conductance, and dissolved oxygen) were monitored continuously at five sites for periods ranging from 24 hours to several days during July-October 2006, and March, May, July, and August 2007. The same four properties plus transparency and turbidity were measured, and chloride, sulfate, residue, nutrients, total organic carbon, biochemical oxygen demand, carbonaceous biochemical oxygen demand, chlorophyll- $a$, pheophytin- $a$, and suspended sediment were sampled periodically (one to five times per month during 2006-07) at five sites. Water temperature, $\mathrm{pH}$, specific conductance, dissolved oxygen, transparency, and turbidity were measured, and the fecal indicator bacteria Enterococci, Escherichia (E.) coli, and total coliform were sampled periodically at all 10 sites.

Stream-habitat data were collected at five sites three times during the study, July-August 2006, March 2007, and July-August 2007. At each site, a representative stream reach was selected and within this reach, five evenly-spaced stream transects were determined. At each transect, stream (wetted channel width, water depth, bottom material, instream cover) and riparian (bank slope and erosion potential, width of natural vegetation, type of vegetation, percentage tree canopy) attributes were measured. Habitat quality index values indicated aquatic-life-use scores of "intermediate" at all five reaches except for a score of "high" at the Hitchcock site during August 2006.

Benthic macroinvertebrate data were collected from a representative reach at each of the same five sites used for habitat evaluation. A total of 5,126 macroinvertebrate individuals from the five sites sampled were identified. Overall, the most abundant macroinvertebrates belonged to the class Insecta, dominated by the Dipteran family Chironomidae, followed by marine segmented worms (class Polychaeta), Crustacea (class Malacostraca), bivalves (primarily the species Mytilopsis leucophaeata and Mulinia lateralis), and freshwater segmented worms (subclass Oligochaeta).

Benthic macroinvertebrate assemblages were scored using indexes specified by the TCEQ. Aquatic-life-use scores were "limited" during all surveys at the Hitchcock site, at the Fairwood site in July 2006, and at the Bayou Dr site in March 2007. Scores were "intermediate" during all surveys at the
Marchand 519 and Texas City sites, at the Fairwood site in March and July 2007, and at the Bayou Dr site in July 2006 and July 2007.

Fish surveys were done at a representative reach of the same five sites used for habitat evaluation. Fish were collected using a combination of seining and electrofishing methods. After collection and identification at the stream, the fish were released. Fish collected using the seining method were kept separate from fish collected using the electrofishing method for identification and enumeration so that the effectiveness of each method could be assessed.

Thirty-four species of fish representing 28 families were collected from Highland and Marchand Bayous. A total of 6,057 fish were collected. Fish communities were scored using a regional index designed for the Western Gulf Coastal Plain. Aquatic-life-use scores were "limited" during all surveys at the Fairwood, Bayou Dr, and Texas City sites; at the Hitchcock site in August 2006; and at the Marchand 519 site in March 2007. Fish communities were scored as "intermediate" at the Hitchcock site in March and July 2007 and at the Marchand 519 site in July 2006 and August 2007.

\section{References}

Brasher, A.M.D., Wolff, R.H., and Luton, C.D., 2003, Associations among land use, habitat characteristics, and invertebrate community structure in nine streams of the island of Oahu, Hawaii, 1999-2001: U.S. Geological Survey WaterResources Investigations Report 03-4256, 47 p.

Delzer, G.C., and McKenzie, S.W., 2003, Five-day biochemical oxygen demand: U.S. Geological Survey Techniques of Water-Resources Investigations, book 9, chap. A7, section 7.0, available at http://pubs.water.usgs.gov/twri9A7/.

Fauchald, K., and Jumars, P. A., 1979, The diet of wormsA study of polychaete feeding guilds: Oceanography and Marine Biology Annual Review, v. 17, p. 193-284

Fishman, M.J., ed., 1993, Methods of analysis by the U.S. Geological Survey National Water Quality LaboratoryDetermination of inorganic and organic constituents in water and fluvial sediments: U.S. Geological Survey Open-File Report 93-125, 217 p.

Fishman, M.J., and Friedman, L.C., 1989, Methods for determination of inorganic substances in water and fluvial sediments: U.S. Geological Survey Techniques of WaterResources Investigations, book 5, chap. A1, 545 p.

Fram, M., 2006, Most fish kills in ponds are caused by low dissolved oxygen: Oklahoma State University, Oklahoma Cooperative Extension Service, accessed February 1, 2006, at http://biosystems.okstate.edu/waterquality/Projects_ Programs/Pond\%20management/Fish\%20kills-low\%20DO. htm 
Guy, H.P., 1969, Laboratory theory and methods for sediment analysis: U.S. Geological Survey Techniques of WaterResources Investigations, book 5, chap. C1, 58 p.

Hem, J.D., 1985, Study and interpretation of the chemical characteristics of natural water ( $3 \mathrm{~d}$ ed.): U.S. Geological Survey Water-Supply Paper 2254, 263 p.

Hilsenhoff, W.L., 1988, Rapid field assessment of organic pollution with a family-level biotic index: Journal of the North American Benthological Society, v. 7, p. 65-68.

Larkin, T.J., and Bomar, G.W., 1983, Climatic atlas of Texas: Texas Department of Water Resources Report LP-192, $151 \mathrm{p}$.

Linam, G.W., and Kleinsasser, L.J., 1998, Classification of Texas freshwater fishes into trophic and tolerance groups: Texas Parks and Wildlife Department, River Studies Report No. 14,8 p.

Linam, G.W., Kleinsasser, L.J., and Mayes, K.B., 2002, Regionalization of the index of biotic integrity for Texas streams: Texas Parks and Wildlife Department, Report No. 17, 26 p.

Mabe, J.A., and Moring, J.B., 2008, Variation in biotic assemblages and stream-habitat data with sampling strategy and method in tidal segments of Highland and Marchand Bayous, Galveston County, Texas, 2007: U.S. Geological Survey Scientific Investigations Report 2008-5151, 41 p.

Moring, J.B., 2003, Baseline assessment of fish communities, benthic macroinvertebrate communities, and stream habitat and land use, Big Thicket National Preserve, Texas, 19992001: U.S. Geological Survey Water-Resources Investigations Report 03-4270, 33 p.

Mueller, D.K., Martin, J.D., and Lopes, T.J., 1997, Qualitycontrol design for surface-water sampling in the National Water-Quality Assessment Program: U.S. Geological Survey Open-File Report 97-223, 17 p.

Myers, D.N., Stoeckel, D.M., Bushon, R.N., Francy, D.S., and Brady, A.M.G., 2007, Fecal indicator bacteria (version 2.0): U.S. Geological Survey Techniques of Water-Resources Investigations, book 9, chap. A7, section 7.1, available at http://pubs.water.usgs.gov/twri9A7/.

National Climatic Data Center, 2008, Locate station byCounty [Galveston, station Jamaica Beach]: accessed April 30, 2008, at http://www.ncdc.noaa.gov/oa/climate/ stationlocator.html

Patton, C.J., and Truitt, E.P., 1992, Methods of analysis by the U.S. Geological Survey National Water Quality Laboratory-Determination of total phosphorus by a Kjeldahl digestion method and an automated colorimetric finish that includes dialysis: U.S. Geological Survey Open-File Report 92-146, 39 p.
Patton, C.J., and Truitt, E.P., 2000, Methods of analysis by the U.S. Geological Survey National Water Quality Laboratory-Determination of ammonium plus organic nitrogen by a Kjeldahl digestion method and an automated photometric finish that includes digest cleanup by gas diffusion: U.S. Geological Survey Open-File Report 00-170, 31 p.

Porter, S.D., Cuffney, T.F., Gurtz, M.E., and Meador, M.R., 1993, Methods for collecting algal samples as part of the National Water-Quality Assessment Program: U.S. Geological Survey Open-File Report 93-409, 39 p.

Powers, S.L., Jones, G.L., Redinger, P., and Mayden, R.L., 2003, Habitat associations with upland stream fish assemblages in Bankhead National Forest, Alabama: Southeastern Naturalist, v. 2, p. 85-92.

Sawyer, C.N., and McCarty, P.L., 1978, Chemistry for environmental engineering: New York, McGraw-Hill, p. 416432.

Stauffer, J.C., Goldstein, R.M., and Newman, R.M., 2000, Relationship of wooded riparian zones and runoff to fish community composition in agricultural streams: Canadian Journal of Fisheries and Aquatic Sciences, v. 57, p. 307316.

Texas Administrative Code, 2007, Chapter 220, subchapter A, Program for monitoring and assessment of water quality by watershed and river basin: accessed August 20, 2007 , at URL http://info.sos.state.tx.us/pls/pub/readtac\$ext. viewtac?tac_view $=4 \& \mathrm{ti}=30 \& \mathrm{pt}=1 \& \mathrm{ch}=220$

Texas Commission on Environmental Quality, 2003a, Guidance for assessing Texas surface and finished drinking water quality data, 2004: accessed August 11, 2008, at http:// www.tceq.state.tx.us/assets/public/compliance/monops/ water/04twqi/04_guidance.pdf

Texas Commission on Environmental Quality, 2003b, Surface water quality monitoring procedures-Volume 1. Physical and chemical monitoring methods for water, sediment, and tissue: accessed June 27, 2008, at http://www.tceq.state. tx.us/comm_exec/forms_pubs/pubs/rg/rg-415/index.html

Texas Commission on Environmental Quality, 2005, Draft 2004 Texas 303(d) list (May 13, 2005): accessed January 26, 2006, at http://www.tceq.state.tx.us/assets/public/ compliance/monops/water/04twqi/04_303d.pdf

Texas Commission on Environmental Quality, 2007, Surface water quality monitoring procedures-Volume 2. Methods for collecting and analyzing biological assemblage and habitat data: Texas Commission on Environmental Quality, Regulatory Guidance RG-416, 202 p.

Texas Commission on Environmental Quality, 2008, 2008 Texas water quality inventory and 303(d) list, 2008 index of water quality impairments (March 19, 2008): accessed October 27, 2008, at http://www.tceq.state.tx.us/compliance/ monitoring/water/quality/data/08twqi/twqi08.html 
Texas Natural Resource Conservation Commission, 1999, Receiving water assessment procedures manual: Texas Natural Resource Conservation Commission, Water Quality Division, GI-253 [variously paged].

U.S. Environmental Protection Agency, 1993, Determination of ammonia nitrogen by semi-automated colorimetry (method 350.1, revision 2.0), in Methods for the determination of inorganic substances in environmental samples:

U.S. Environmental Protection Agency, Office of Research and Development, EPA-600/R-93-100, 79 p.
Vannote, R.L., Minshall, G.W., Cummins, K.W., Schell, J.R., and Cushing, C.E., 1980, The river continuum concept: Canadian Journal of Fisheries and Aquatic Sciences, v. 37, p. 130-137.

Wershaw, R.L., Fishman, M.J., Grabbe, R.R., and Lowe, L.E., eds., 1987, Methods for the determination of organic substances in water and fluvial sediments: U.S. Geological Survey Techniques of Water-Resources Investigations, book 5, chap. A3, 80 p. 

Appendixes 1-6 


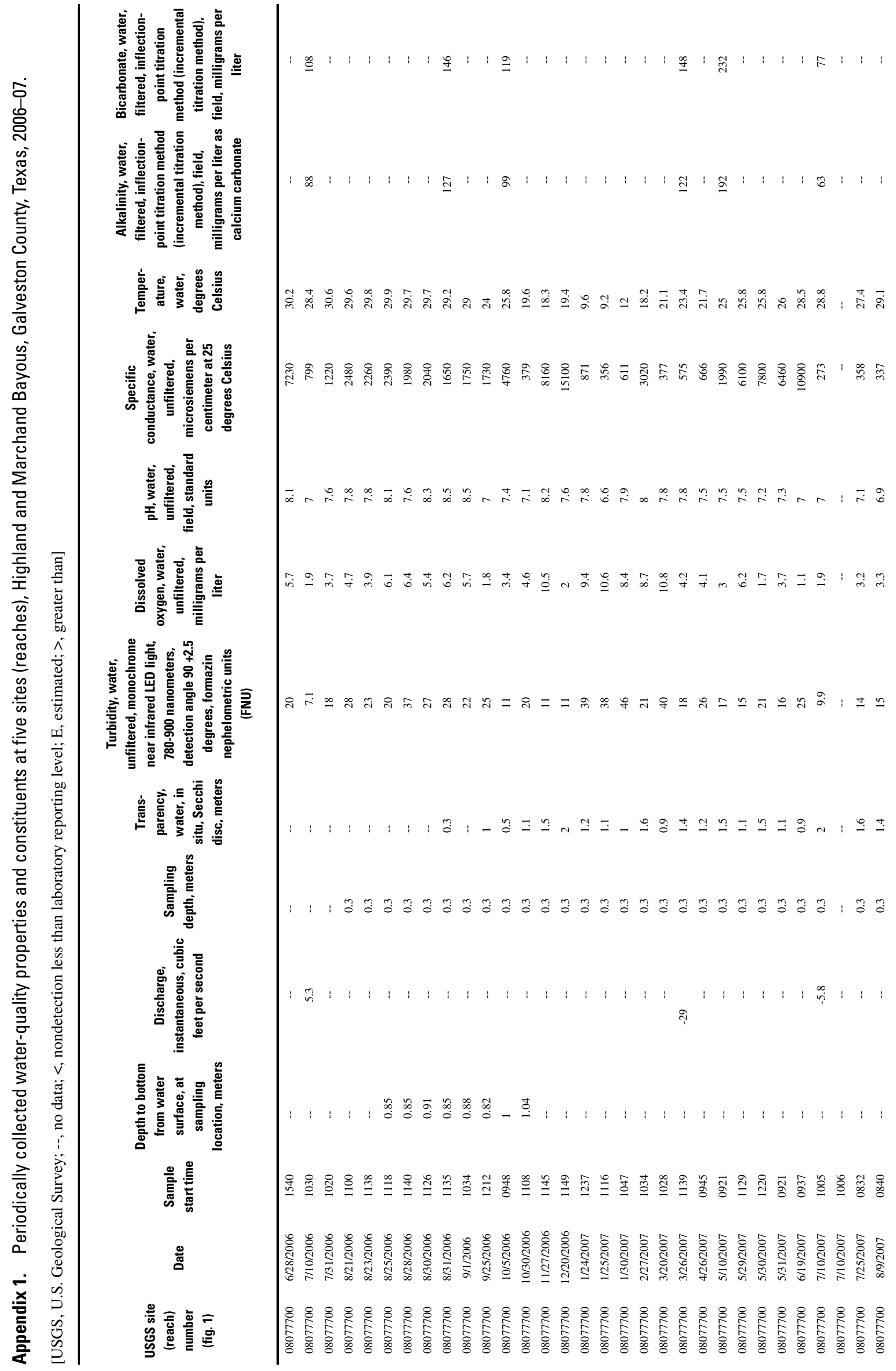




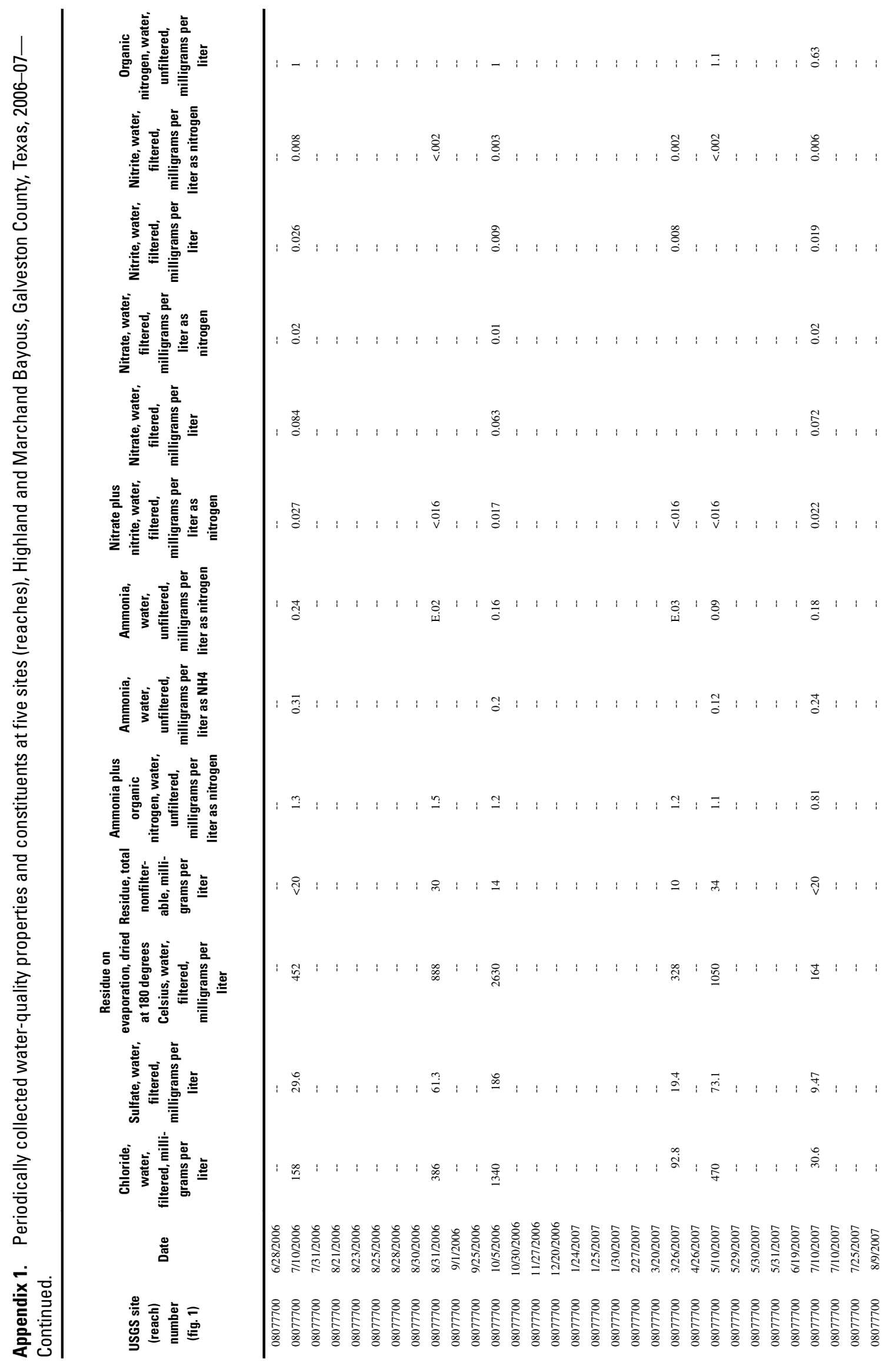




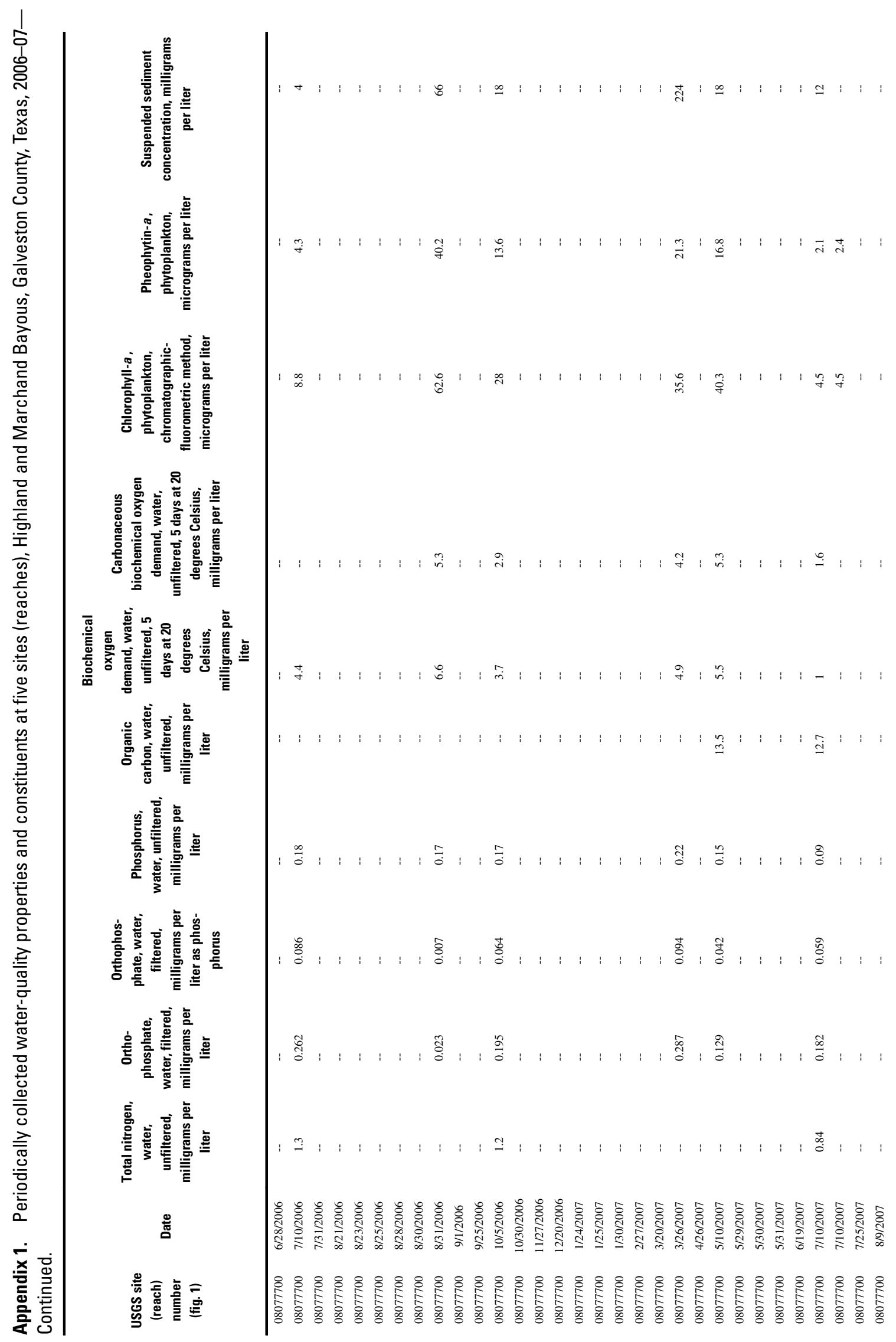




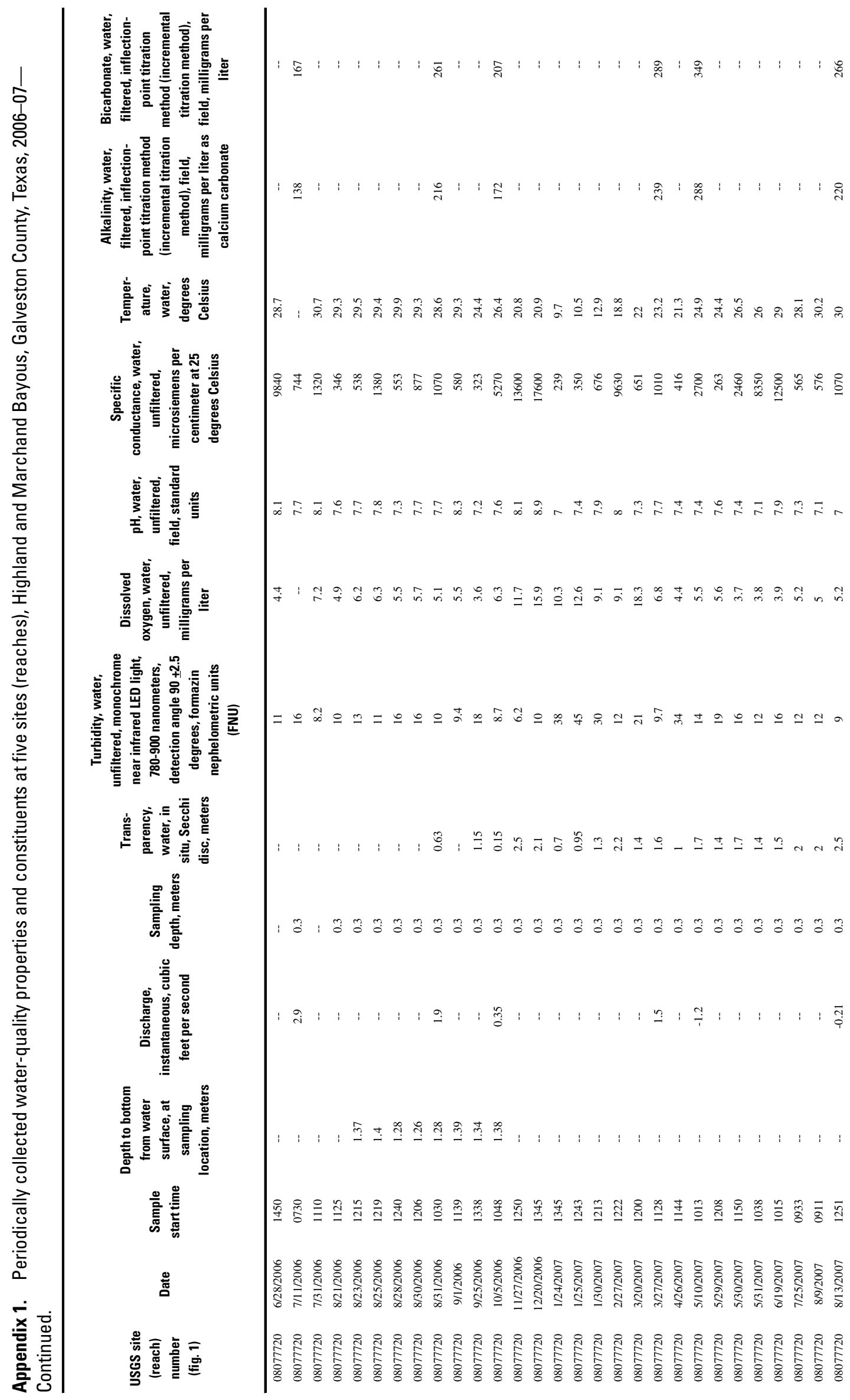




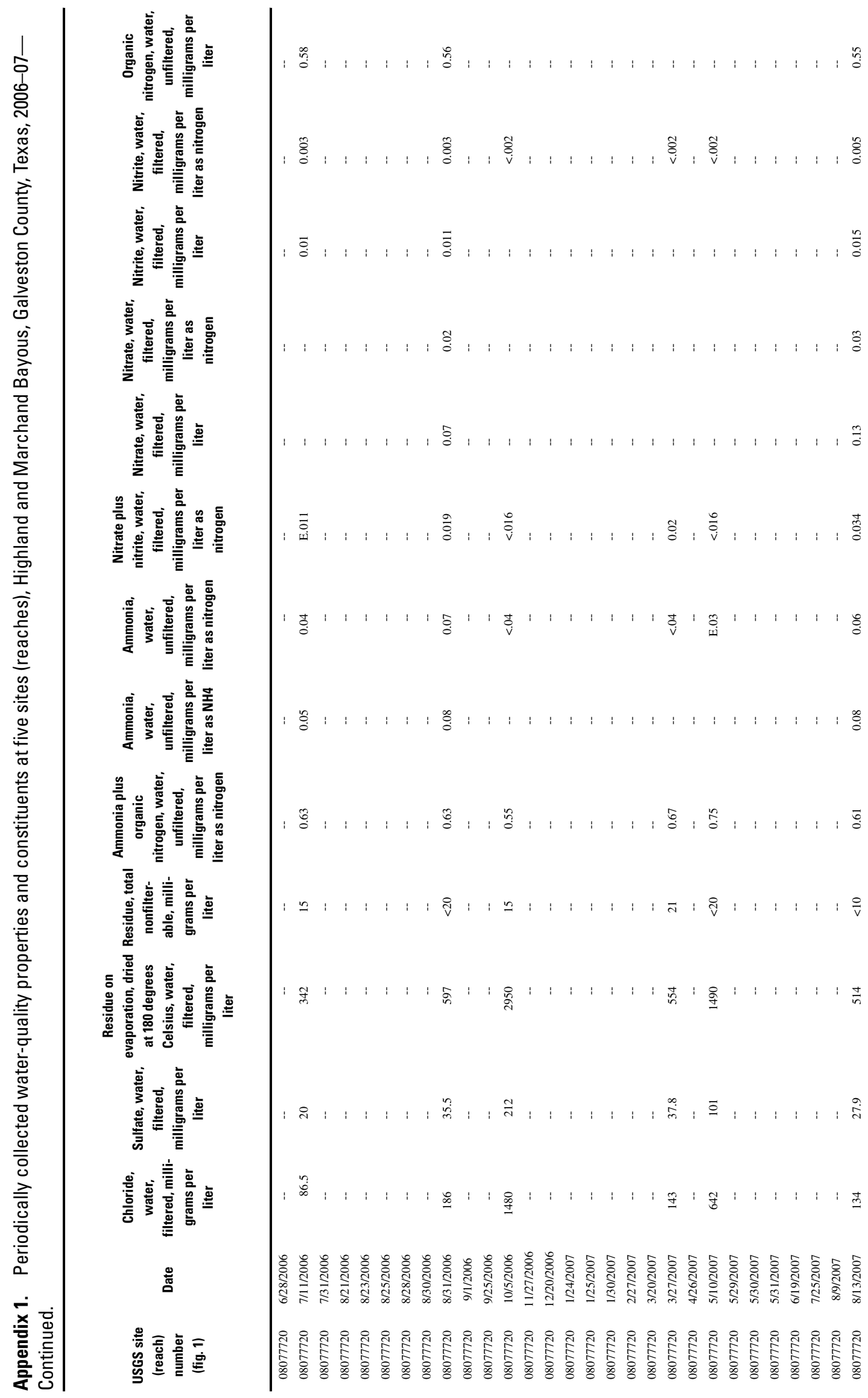




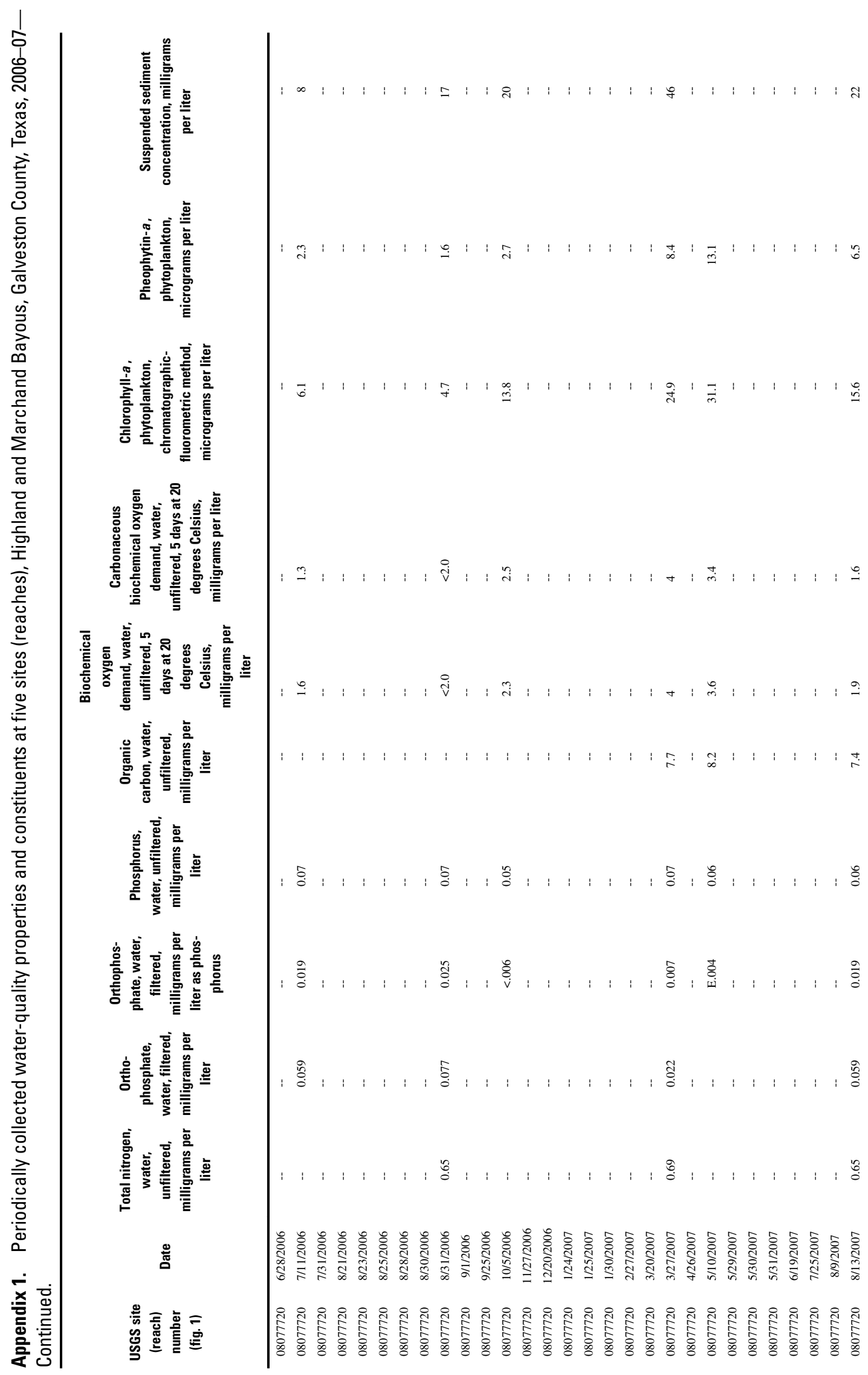




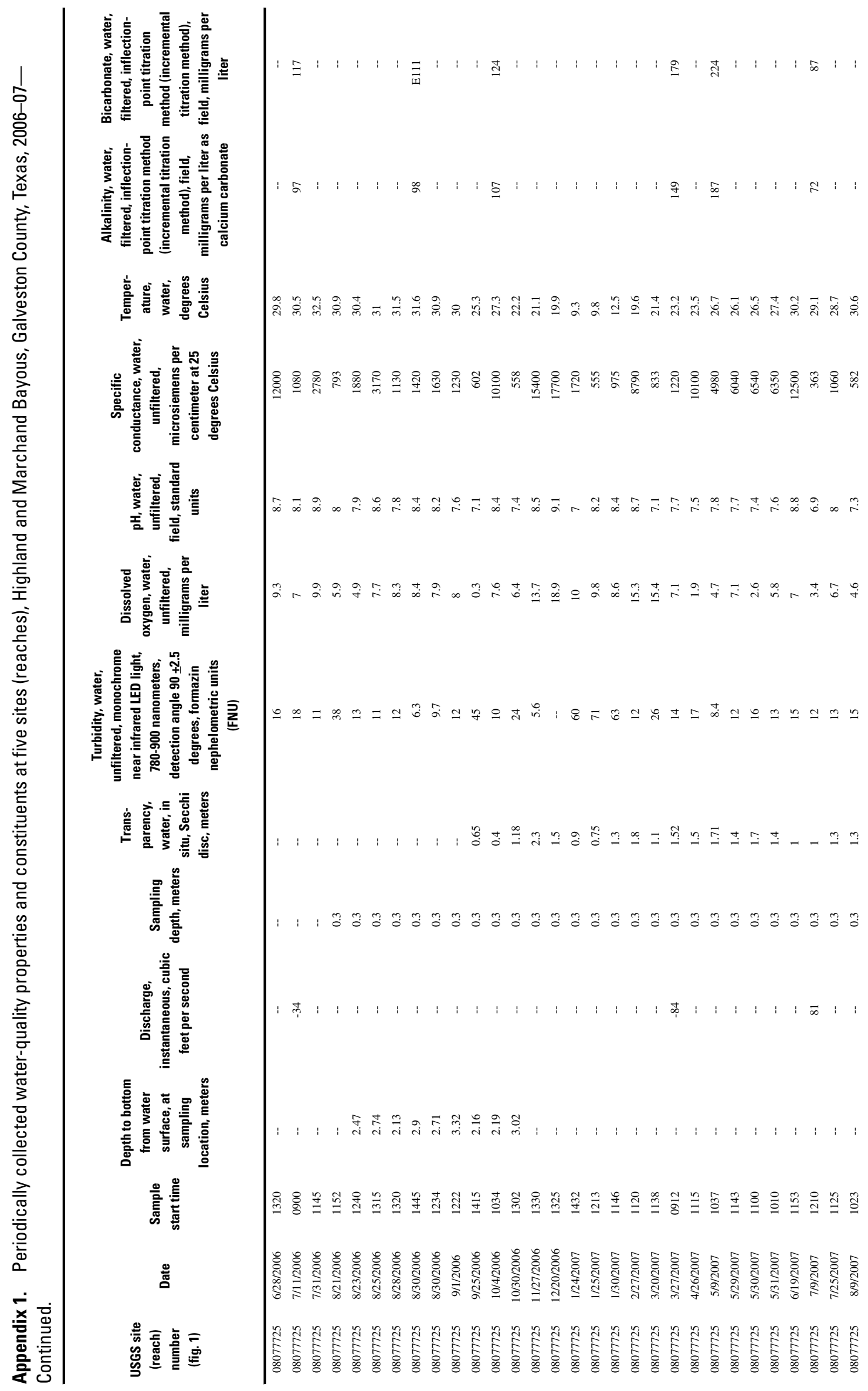




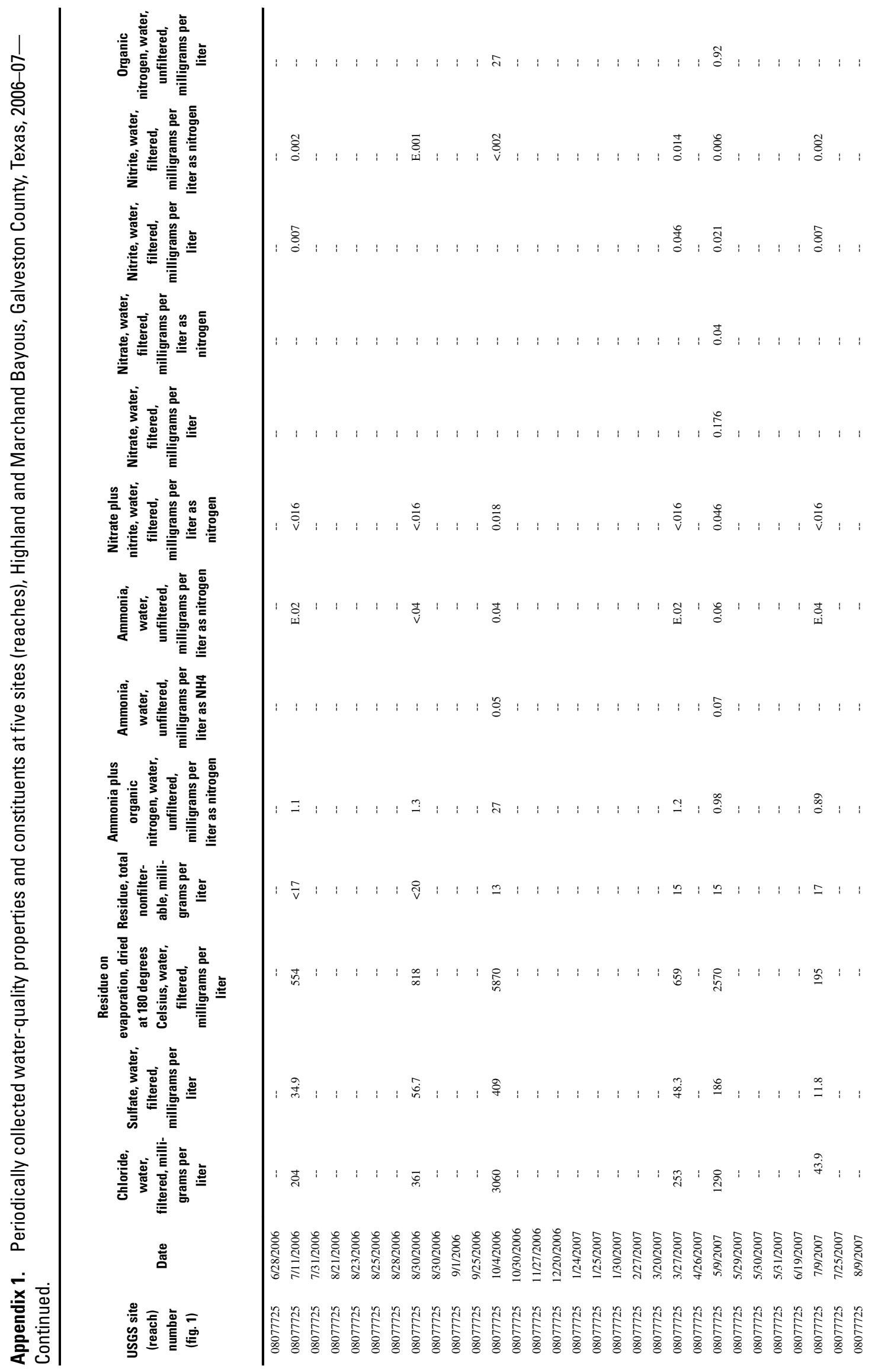




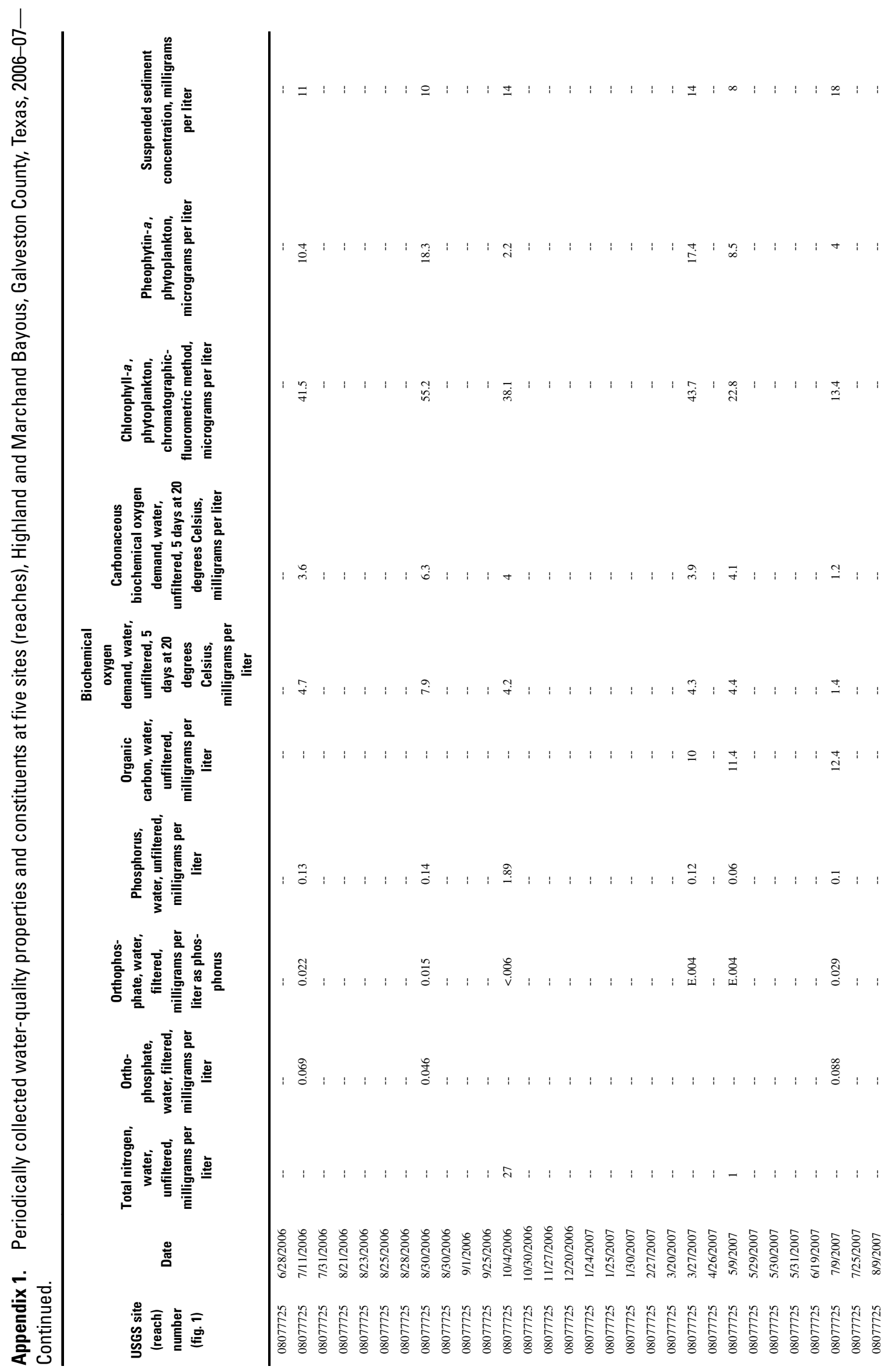




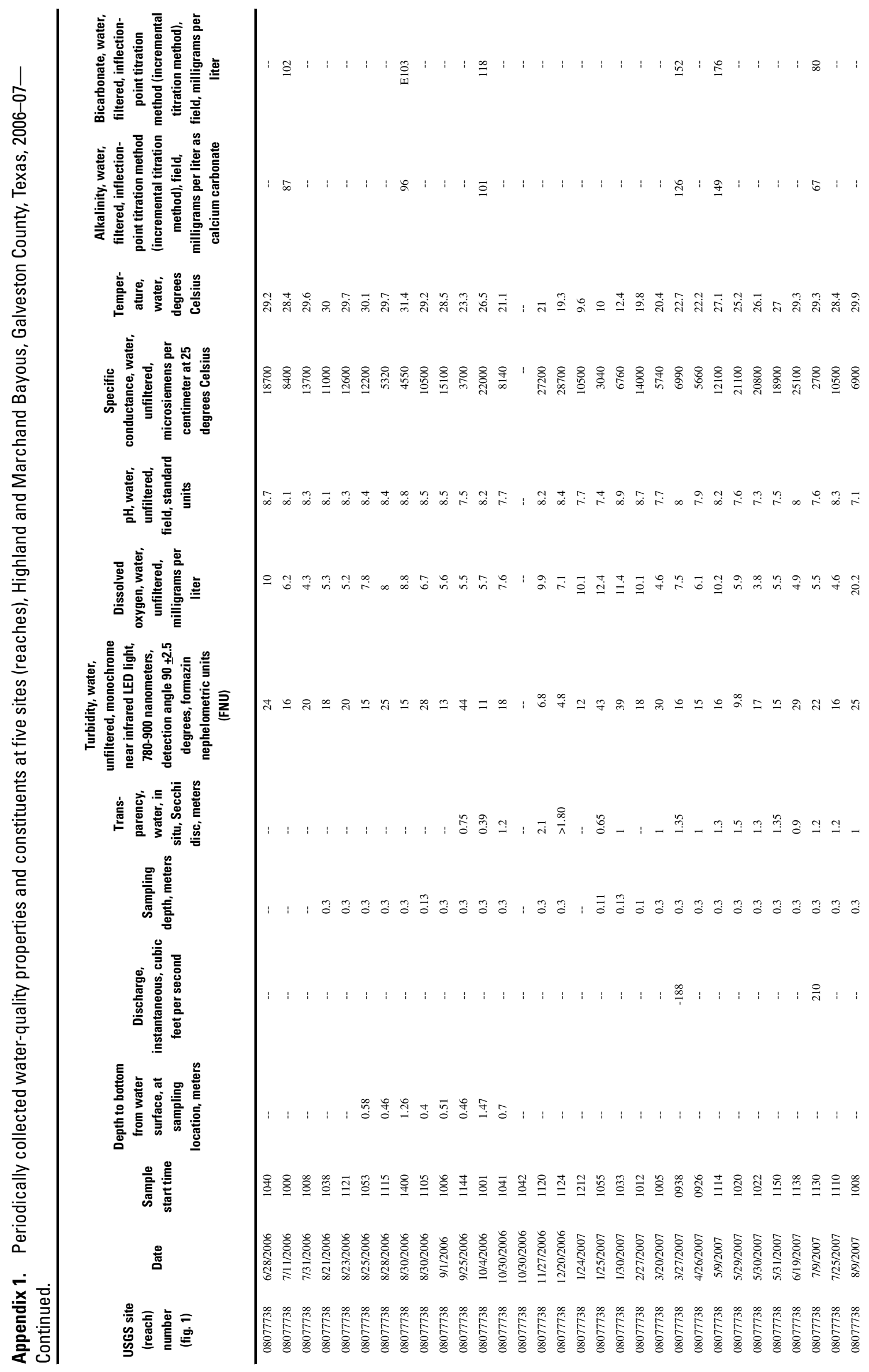




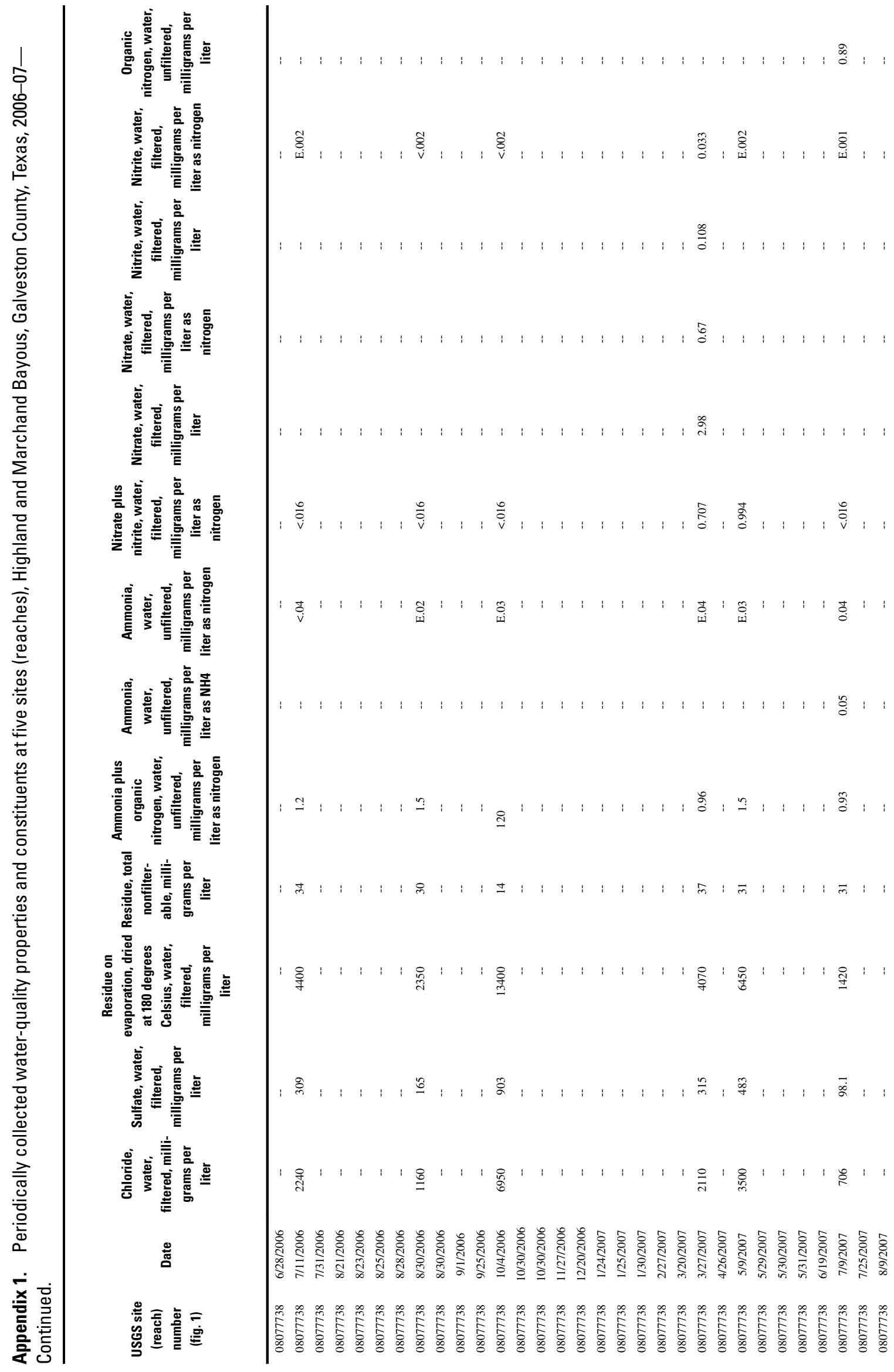




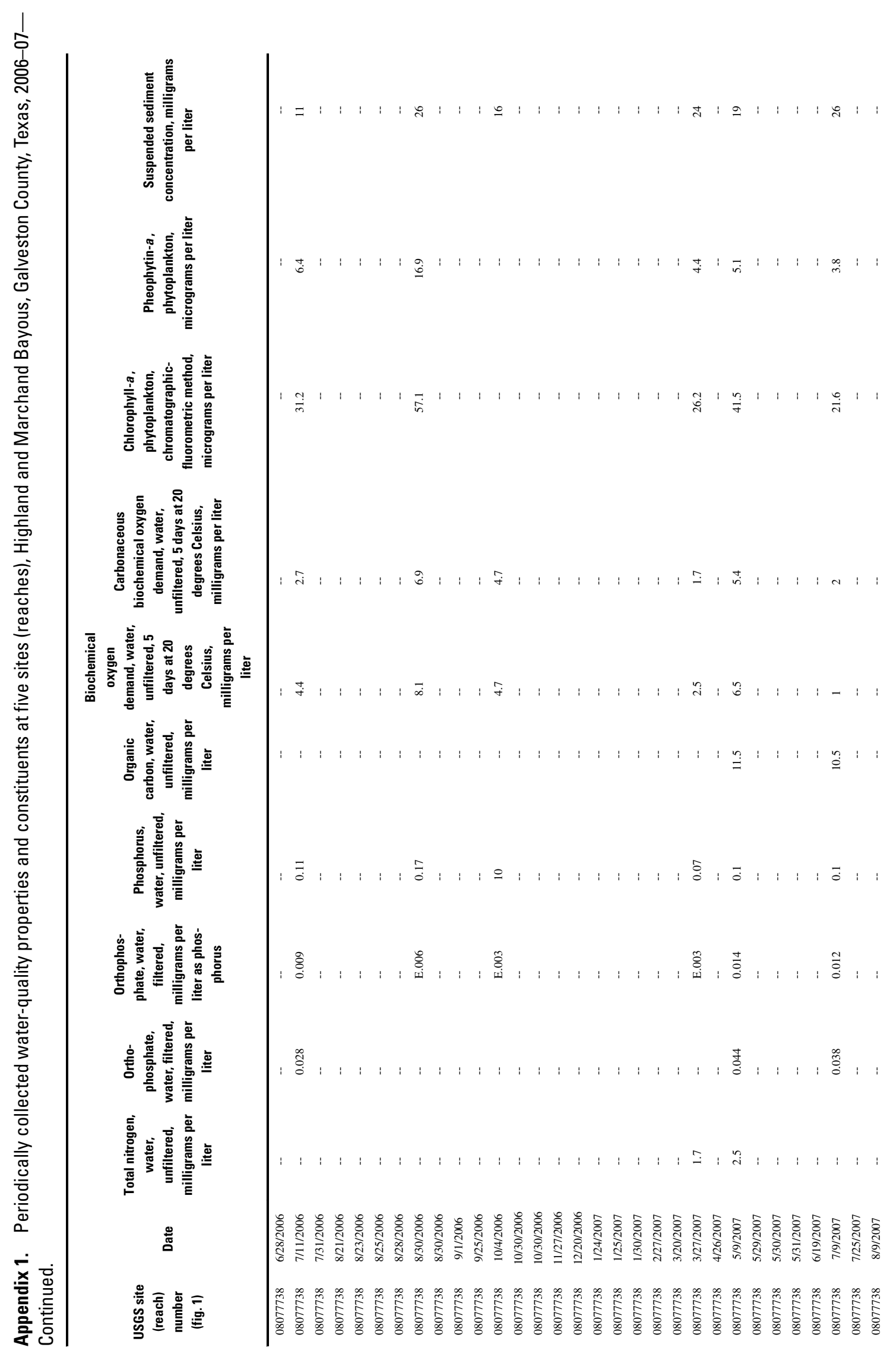




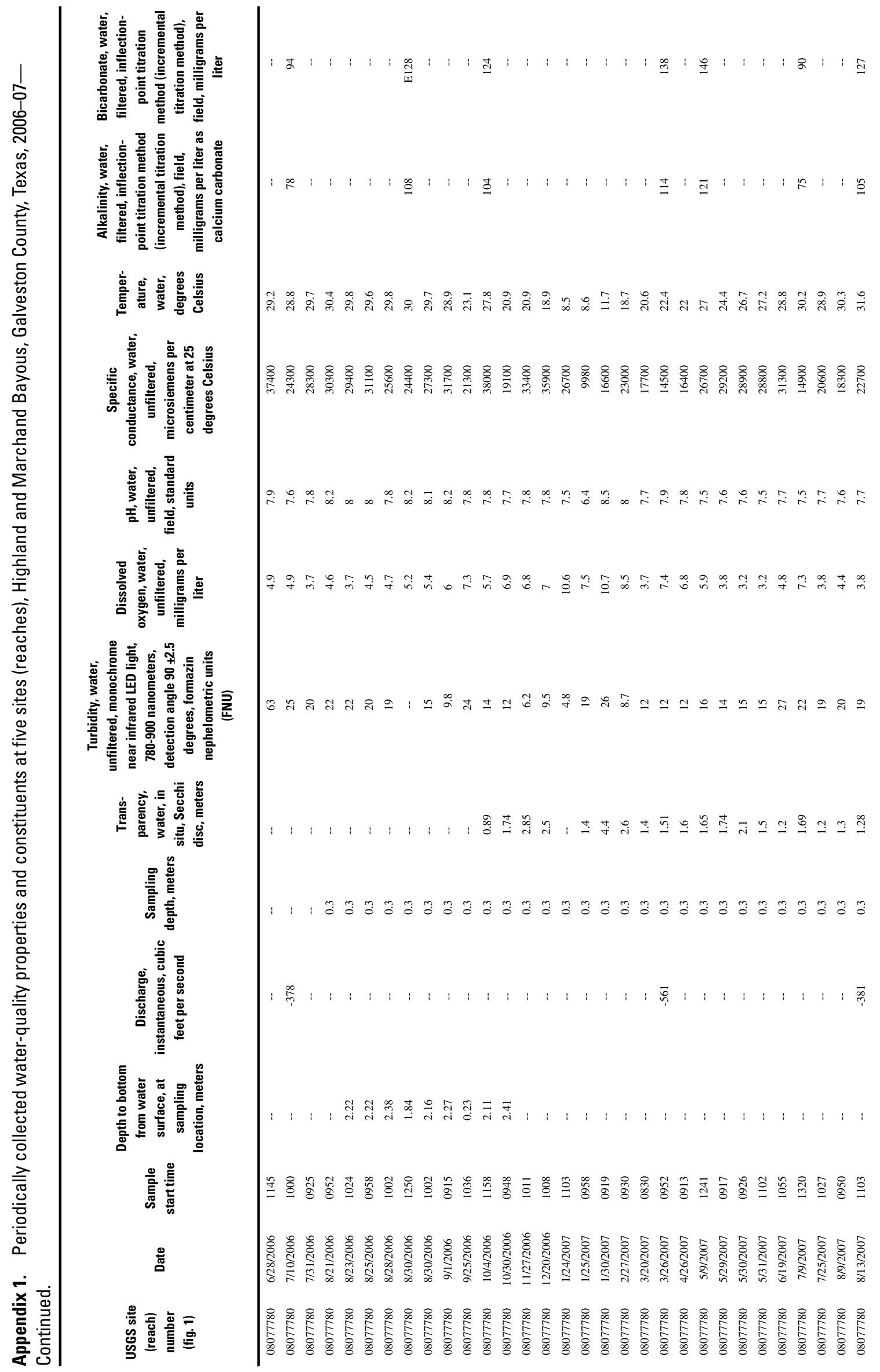




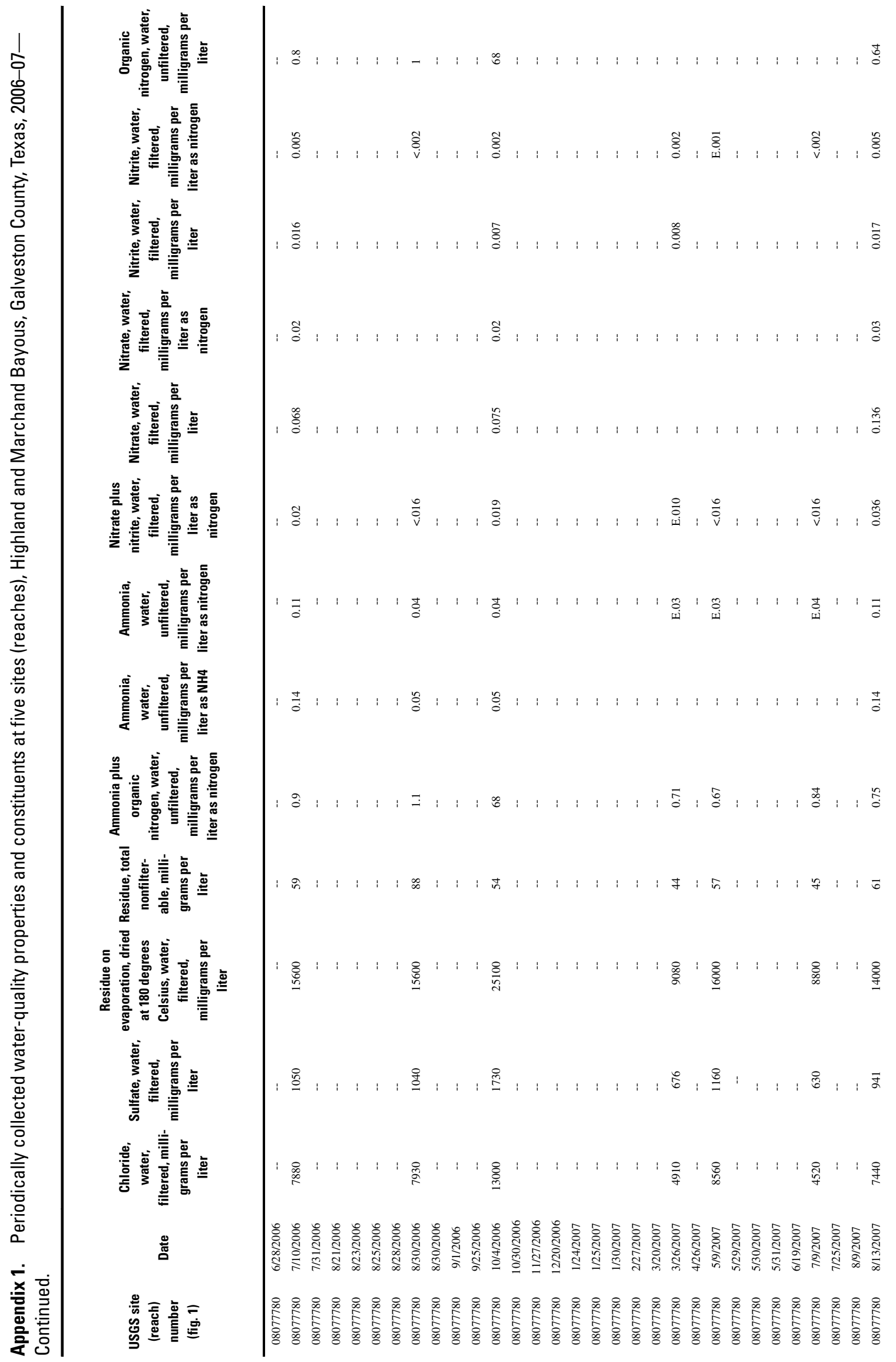




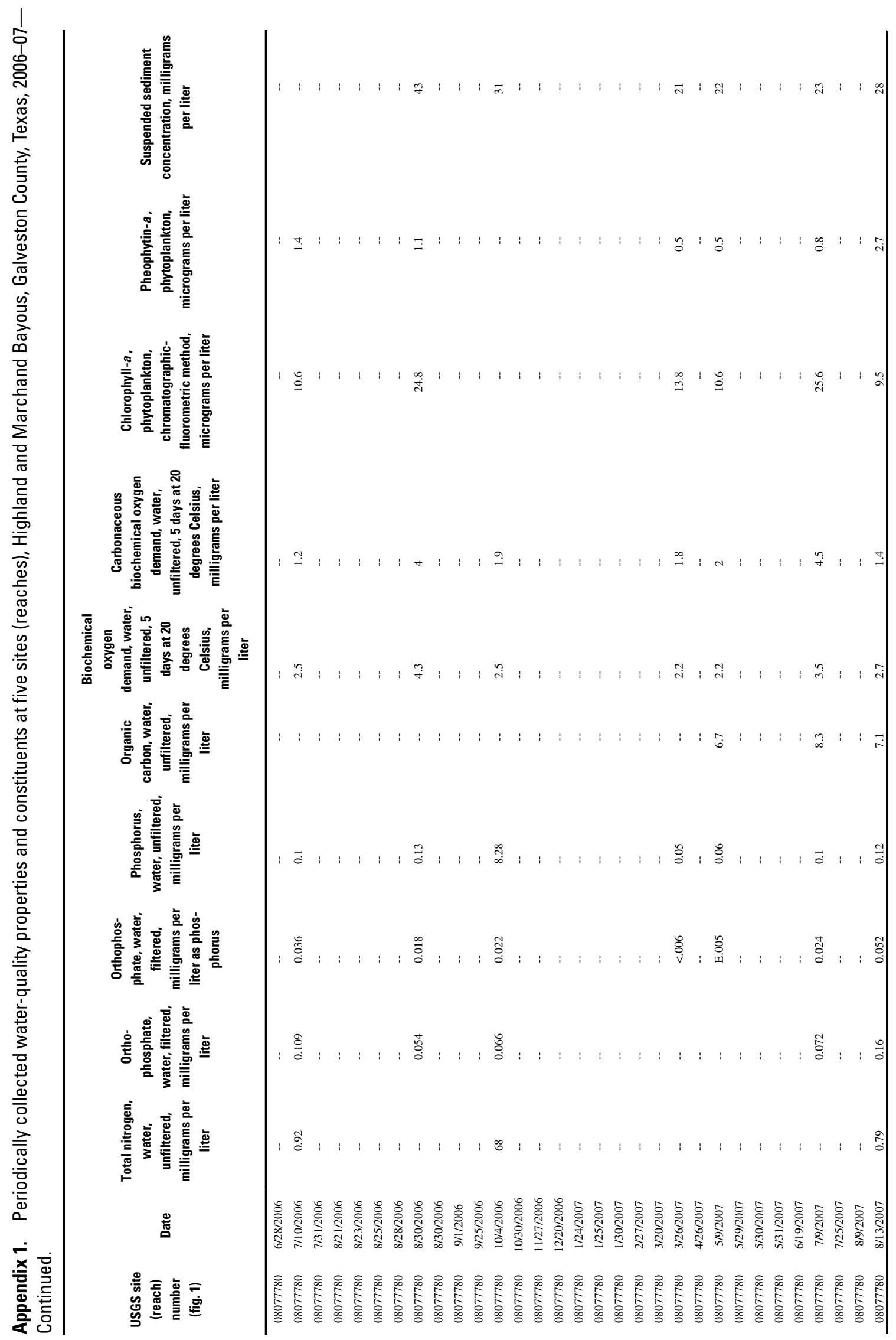




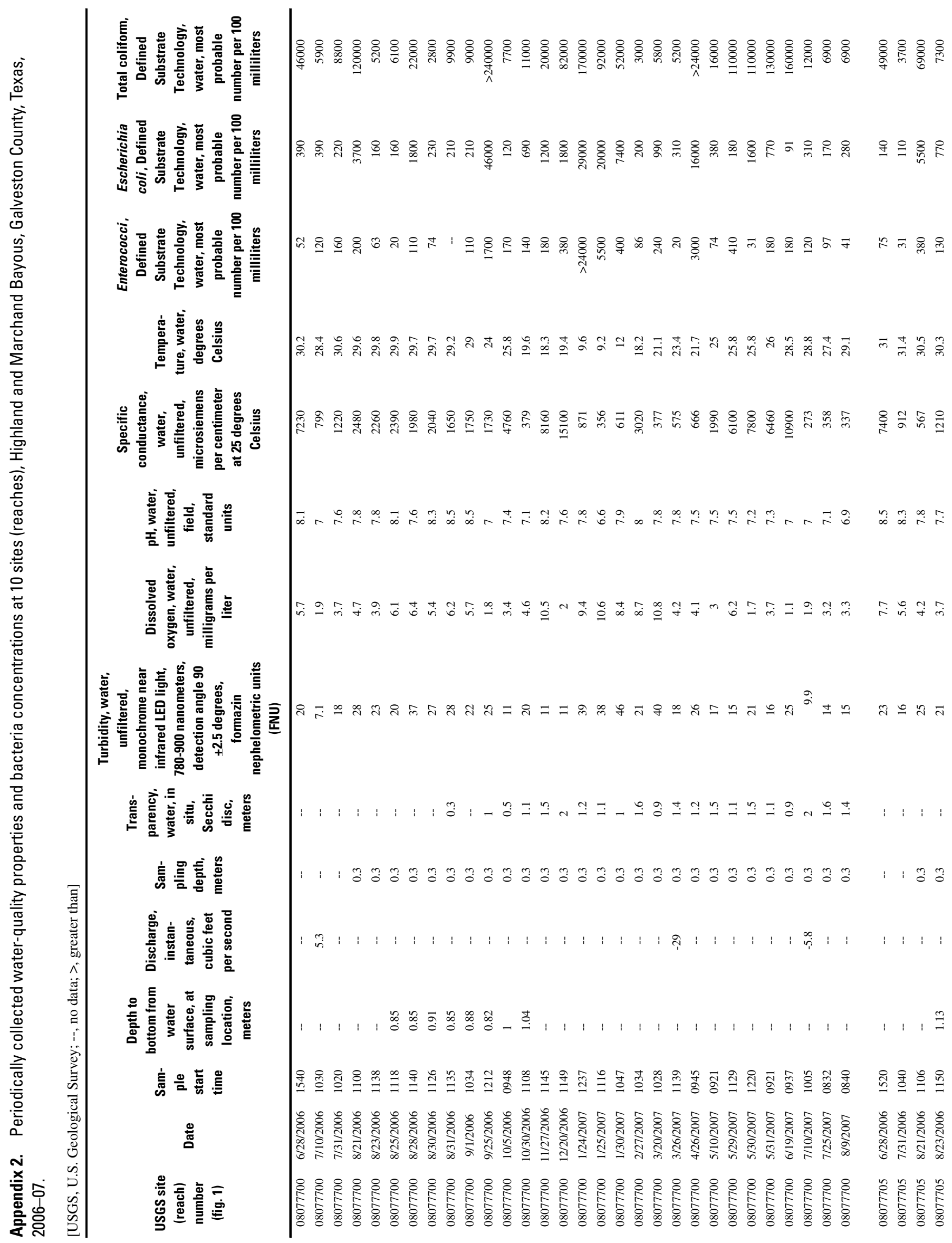




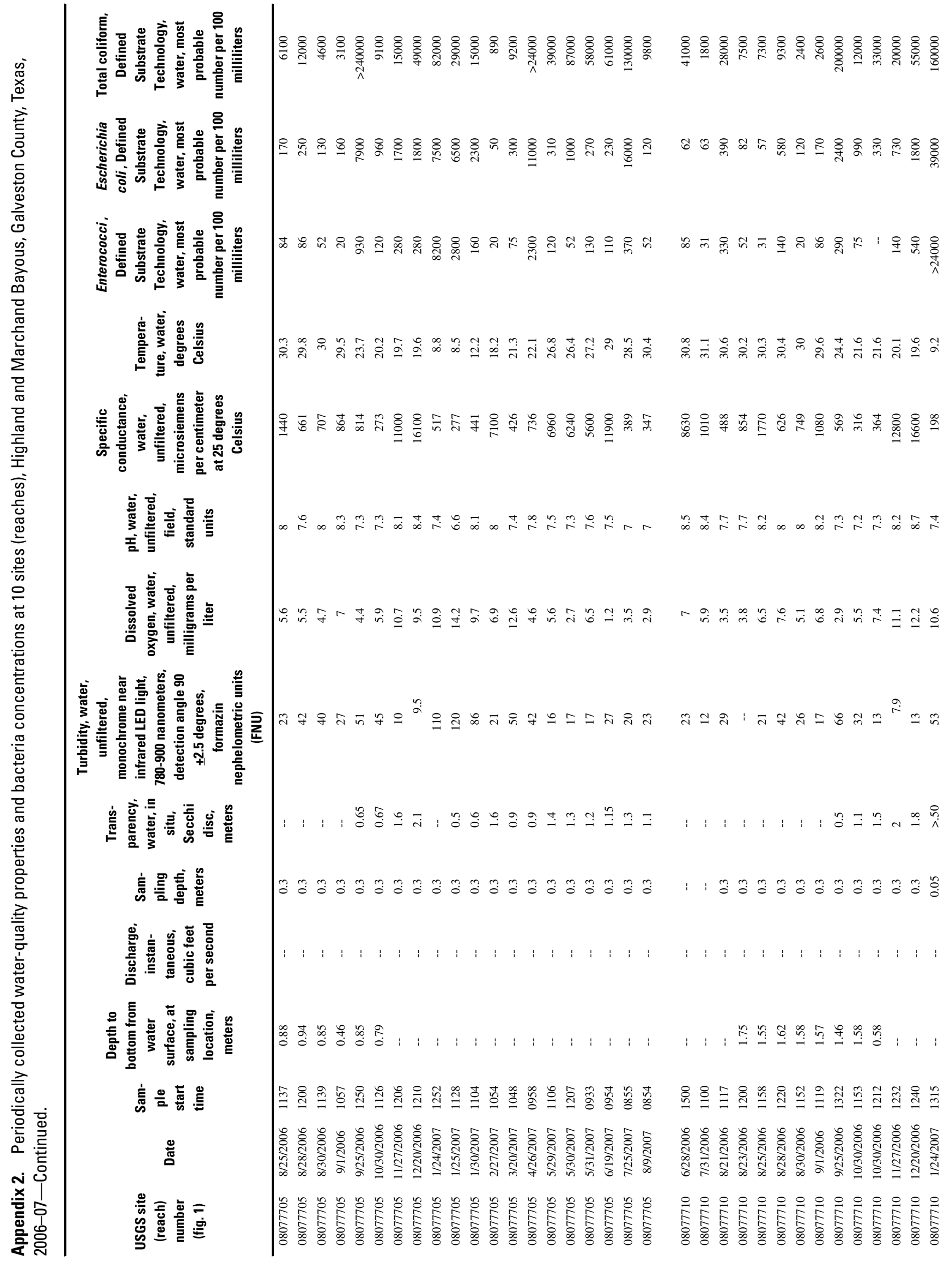




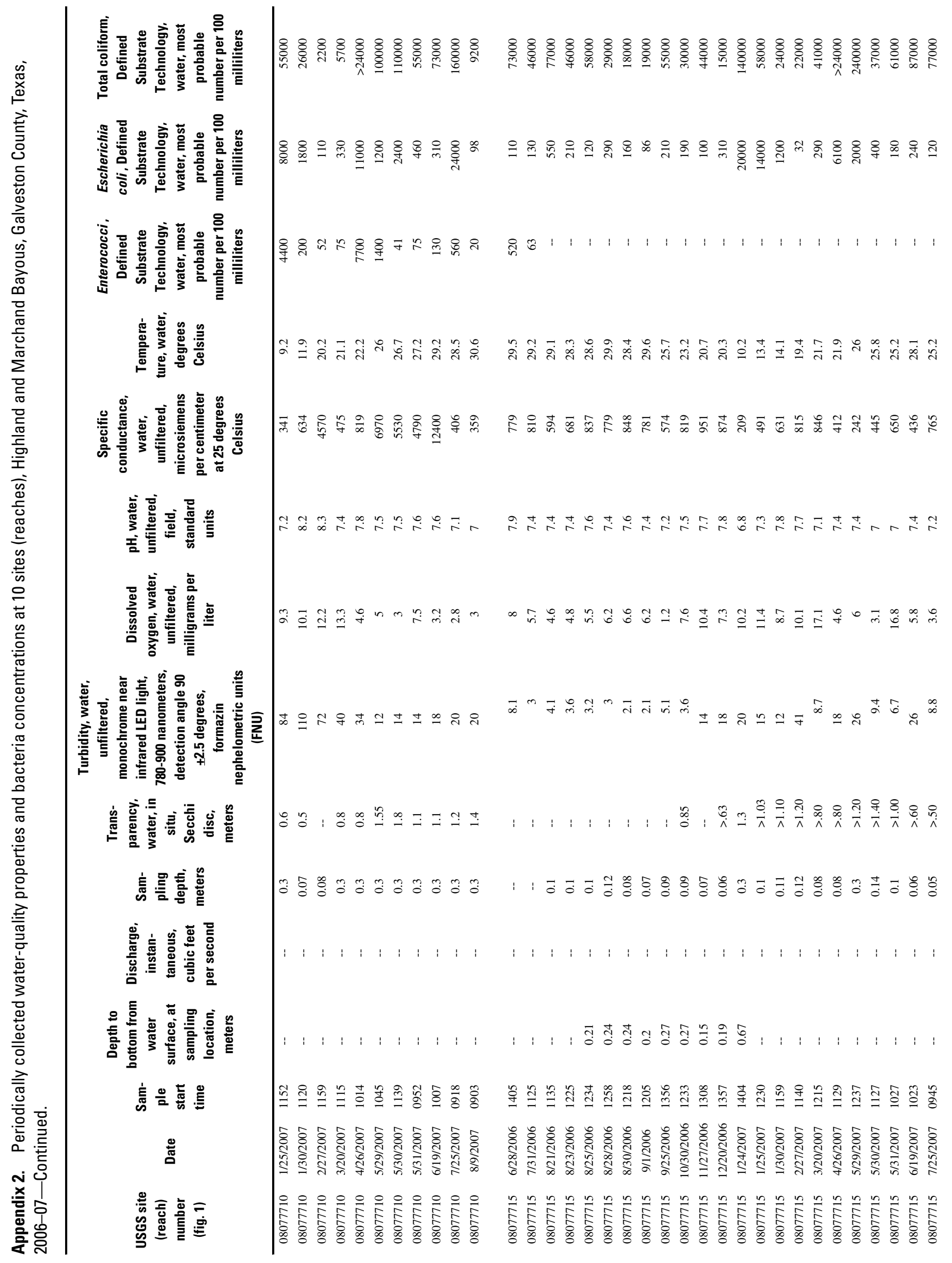




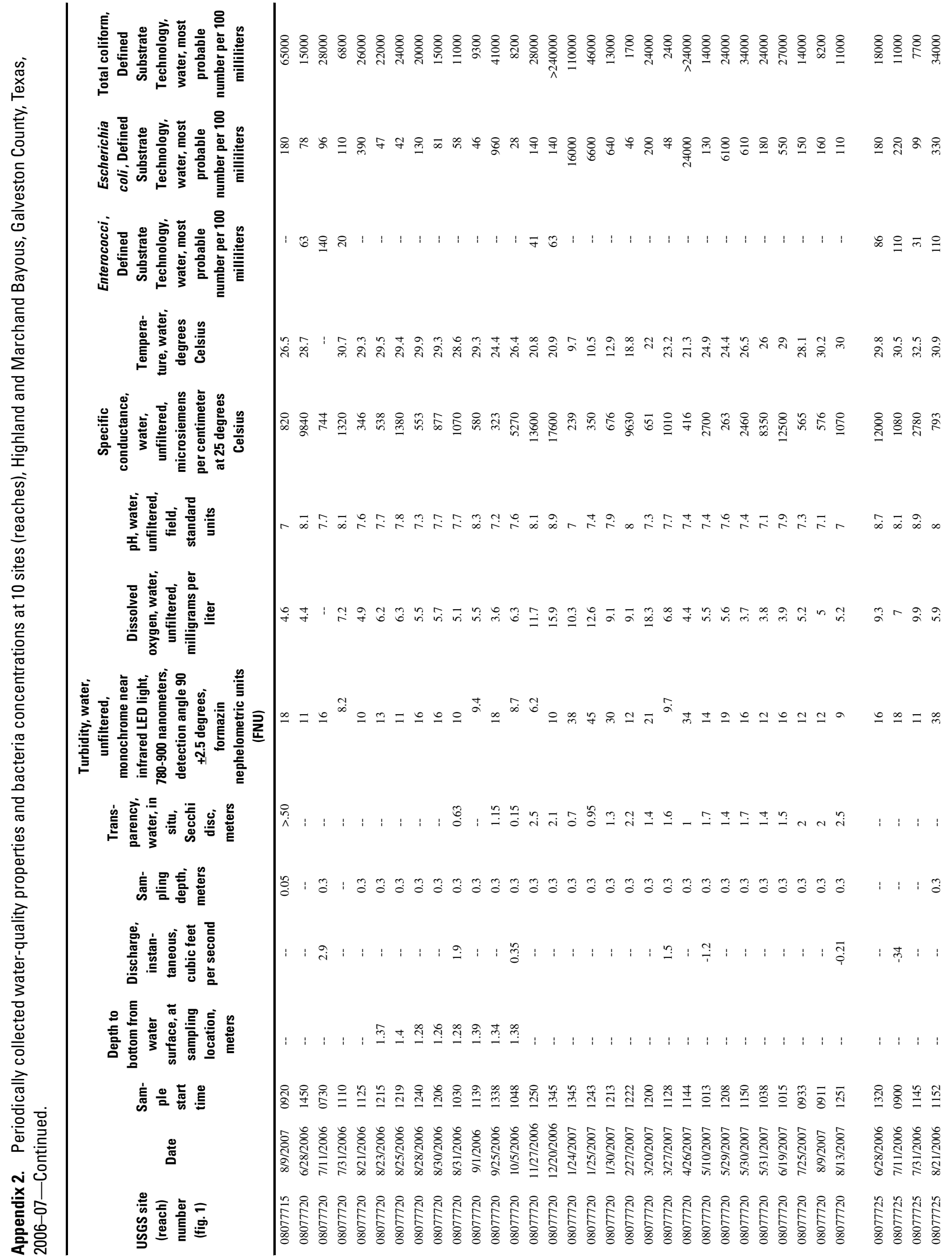




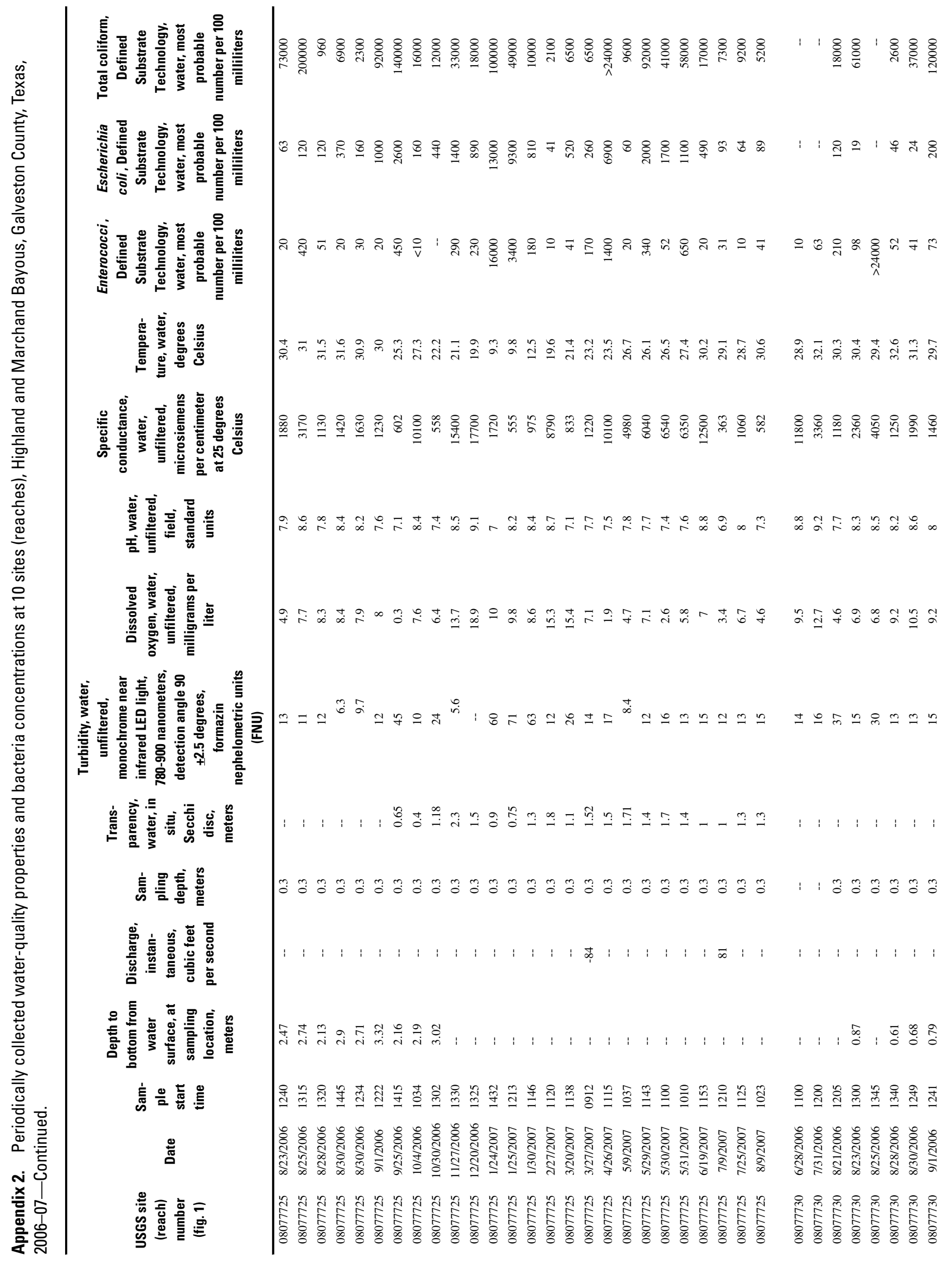




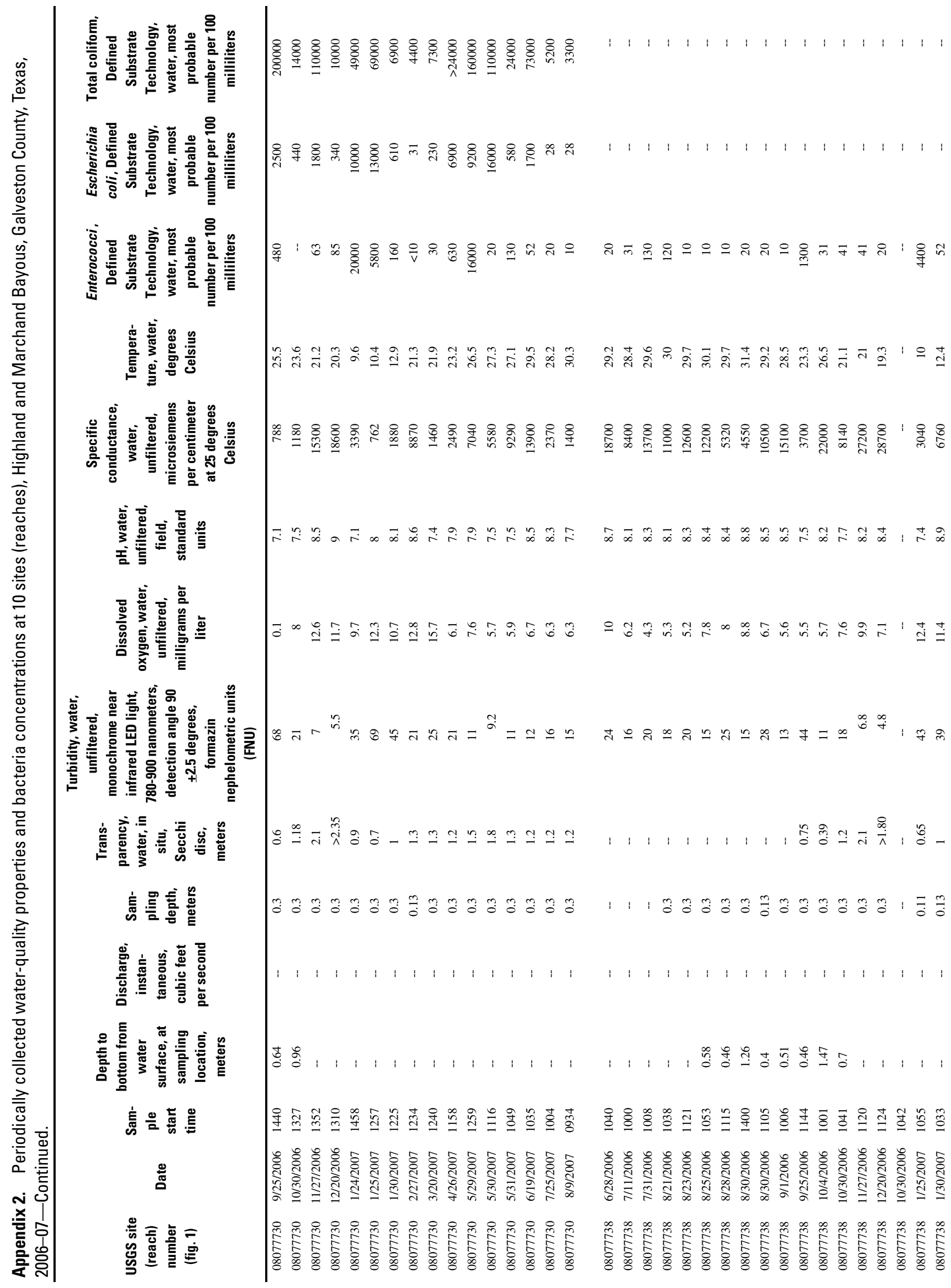




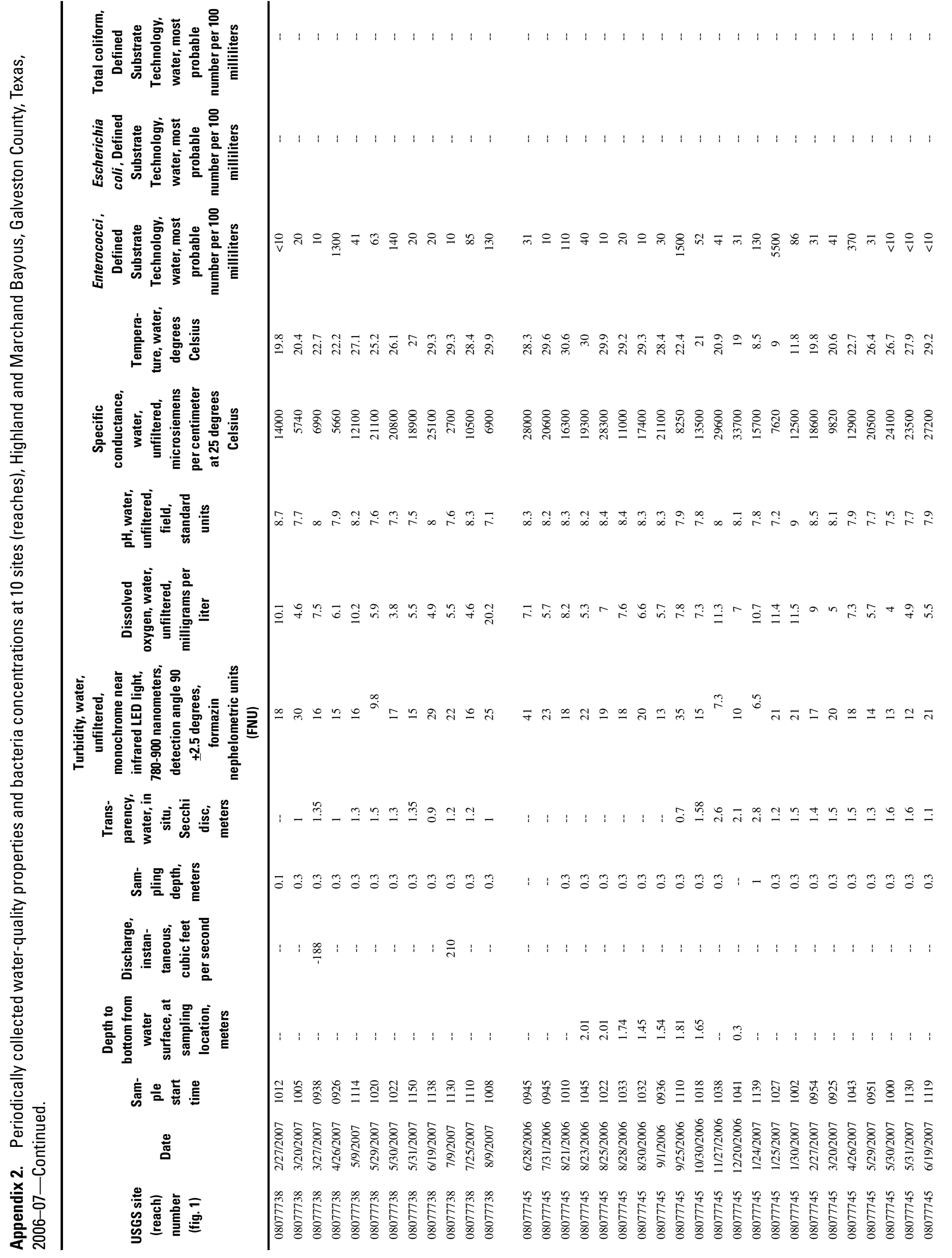




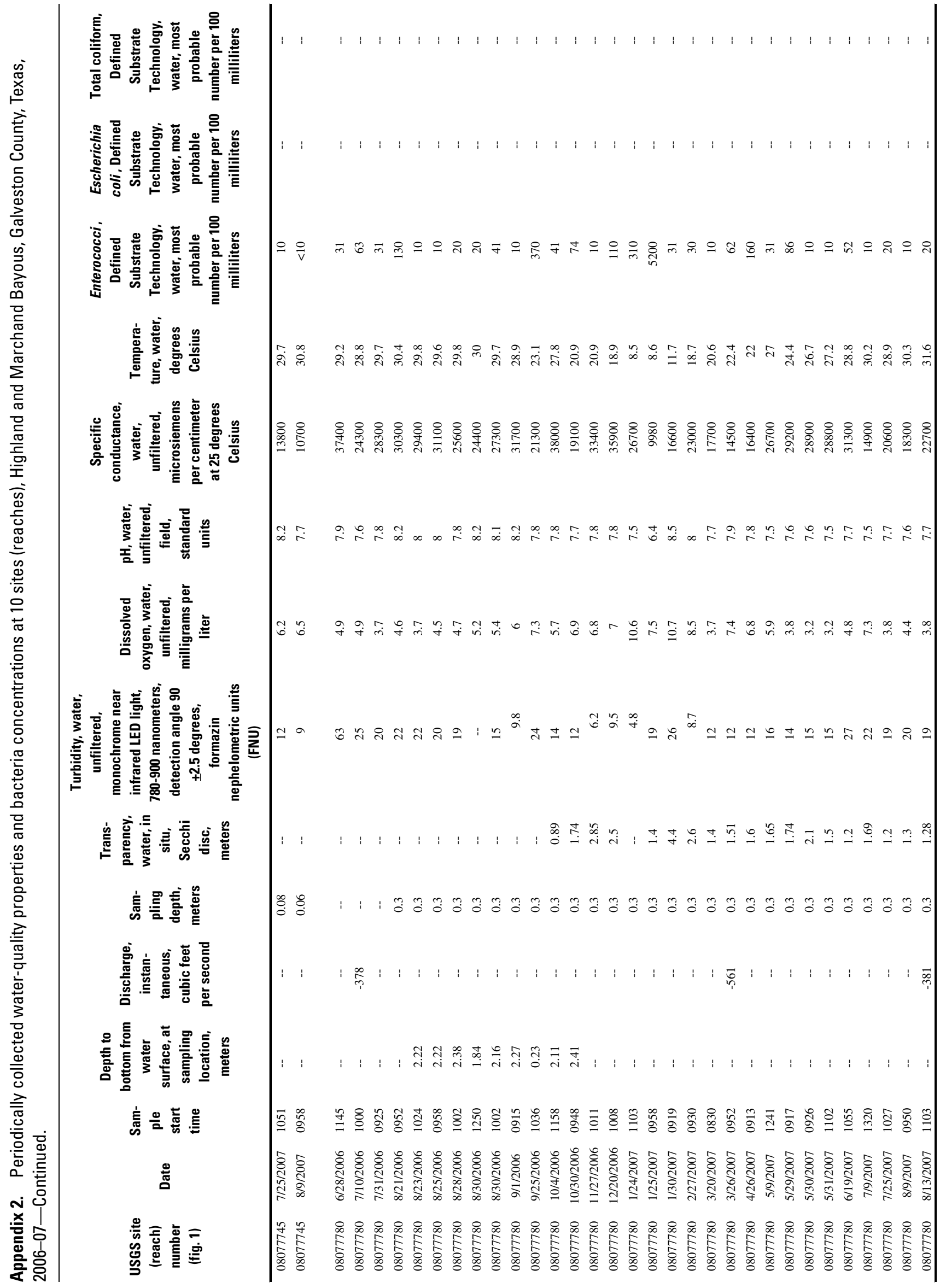




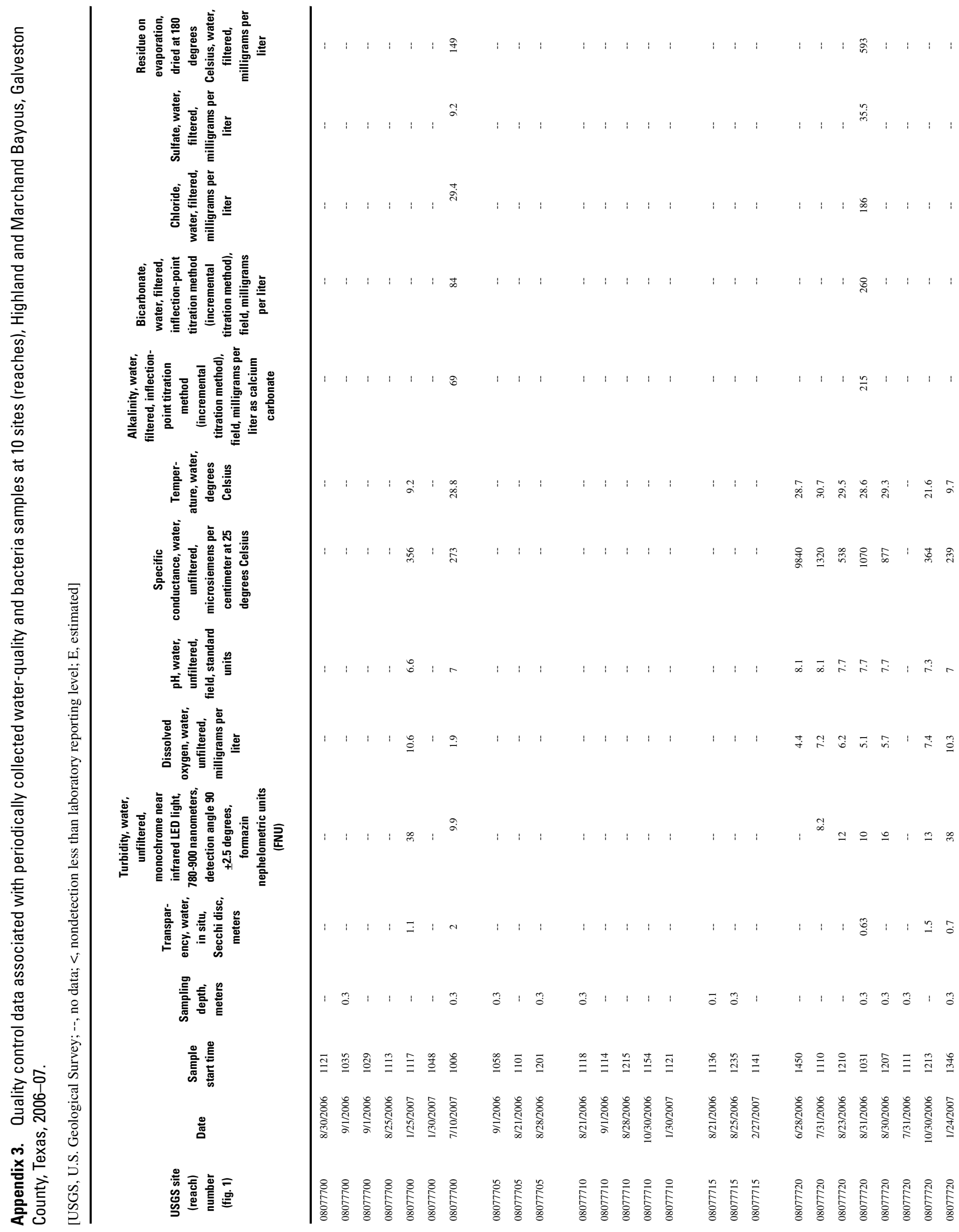




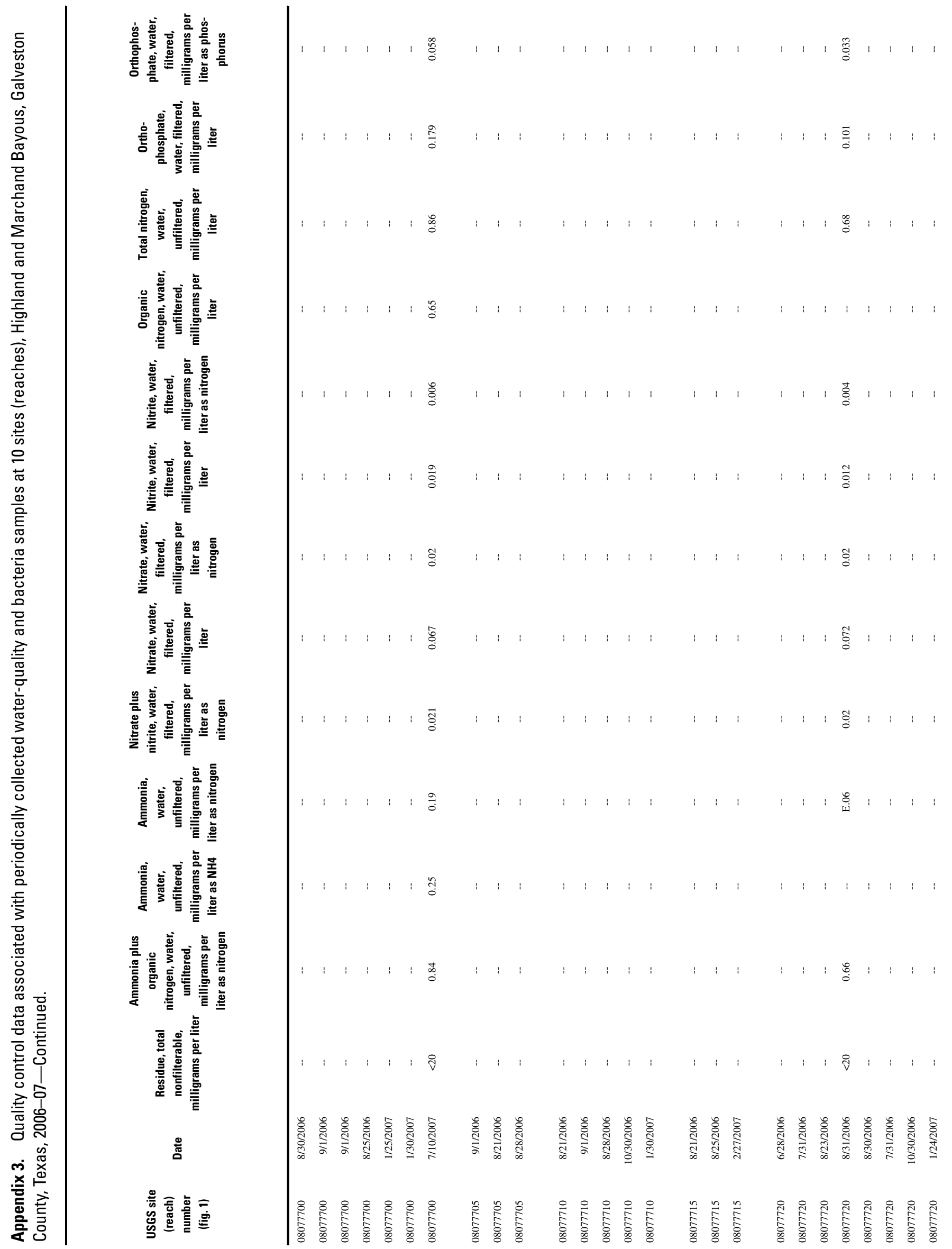




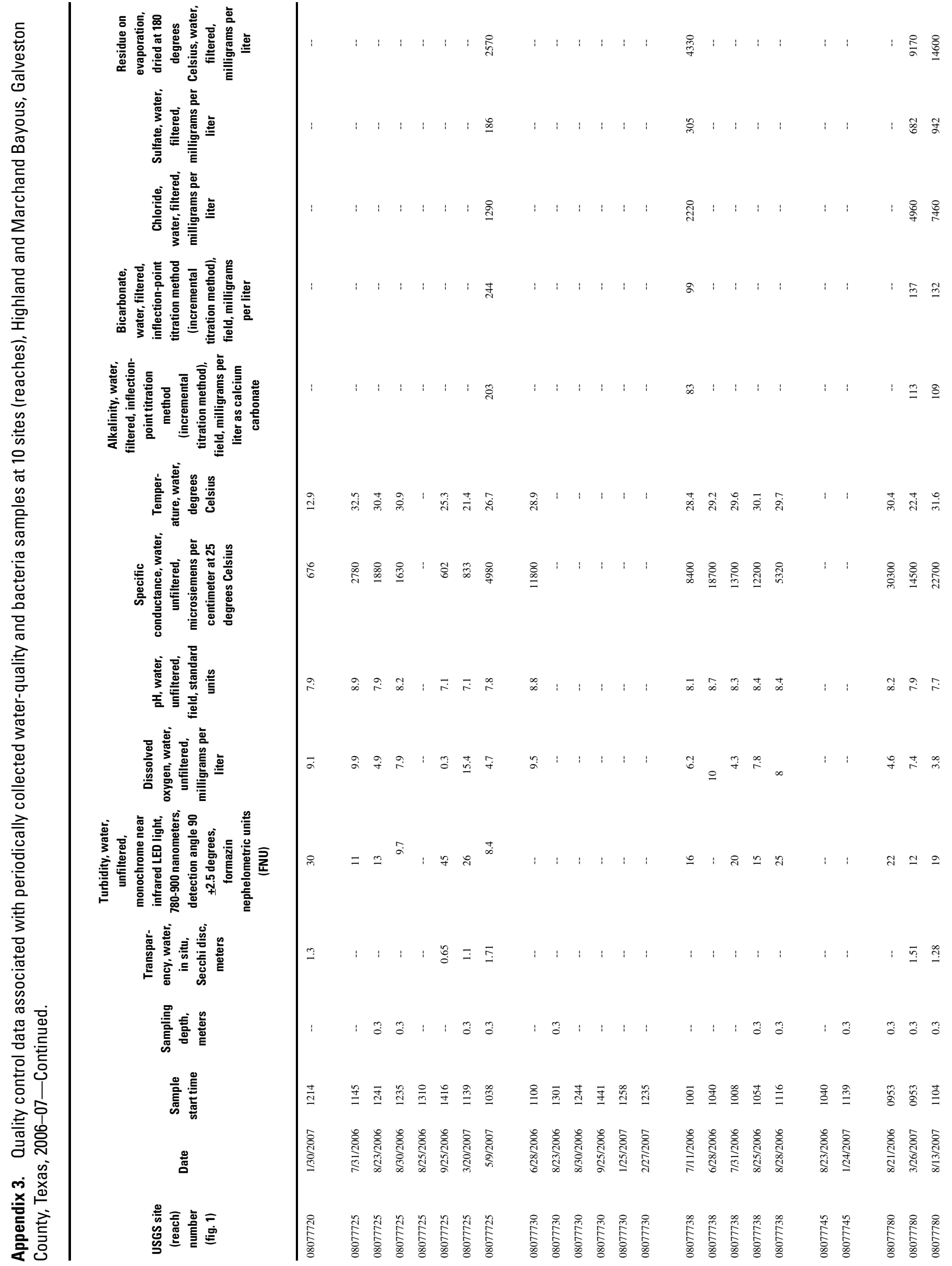




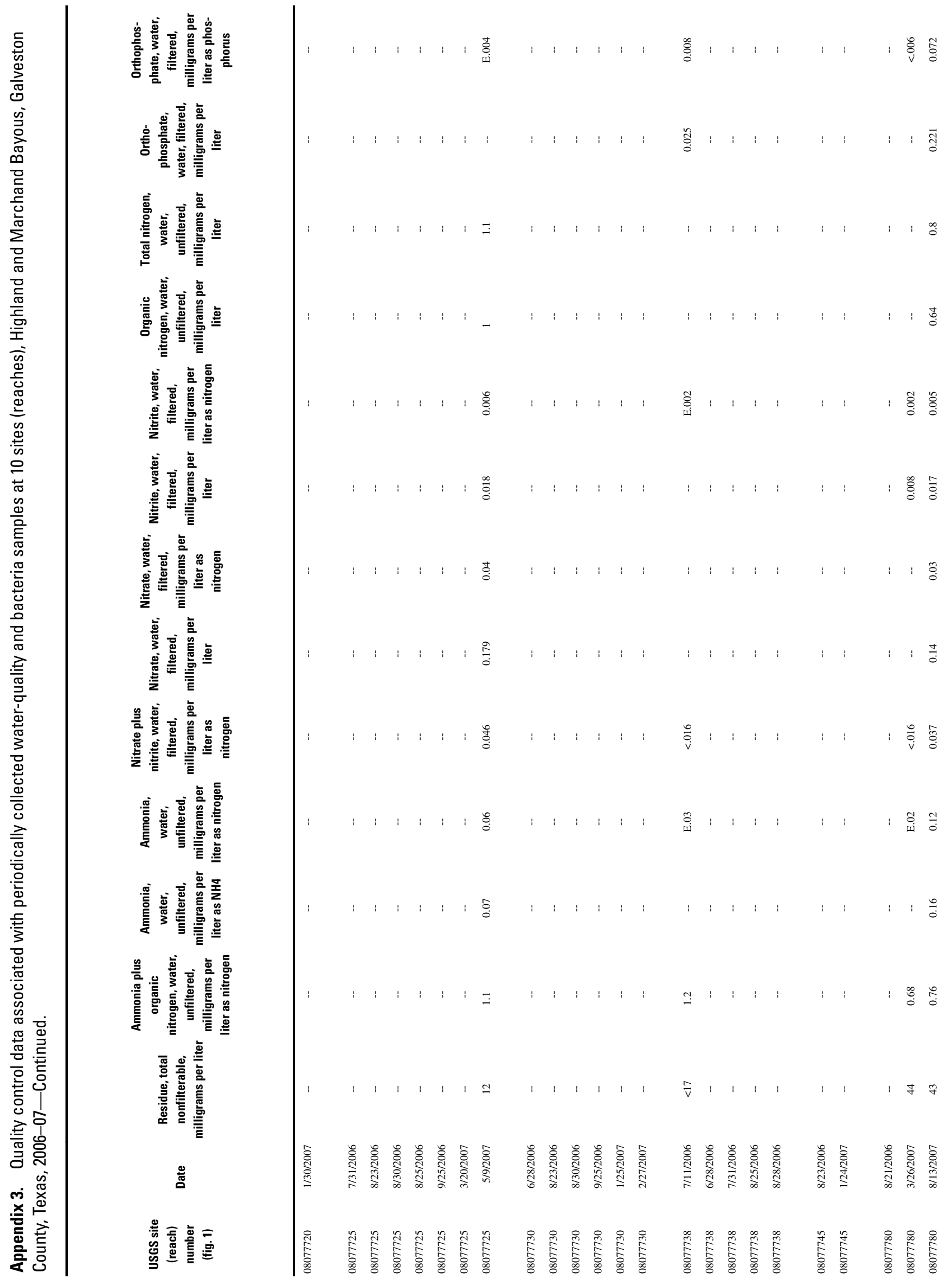




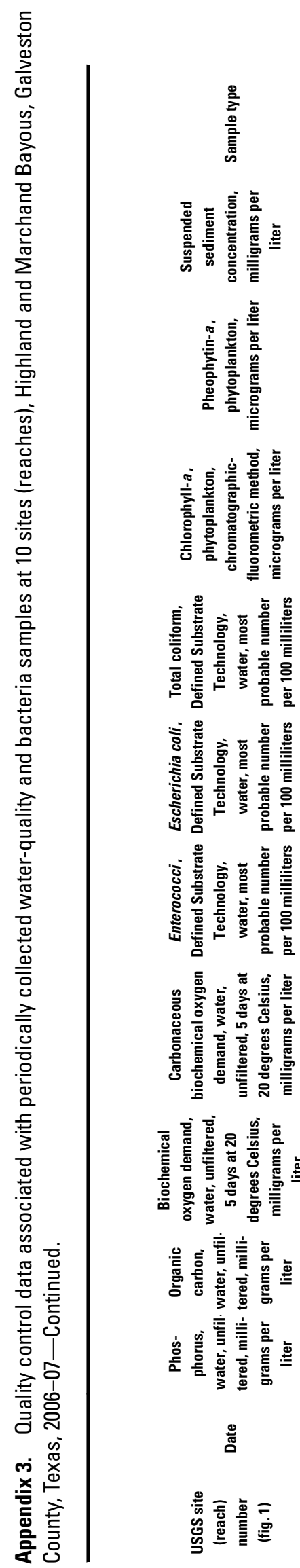

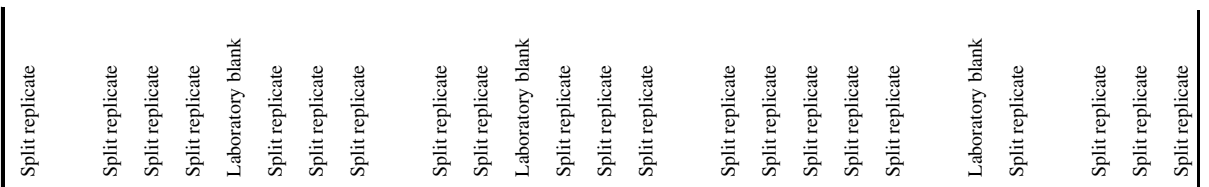

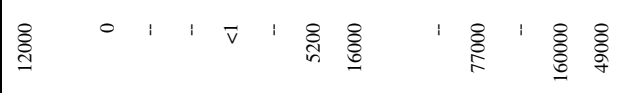

8

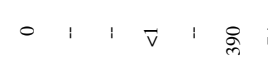

:

:

$8 \div$

$\bar{v} \stackrel{0}{9}$

?

\begin{tabular}{lc}
$\exists$ & $\infty$ \\
\hdashline
\end{tabular}

$\stackrel{2}{v}$

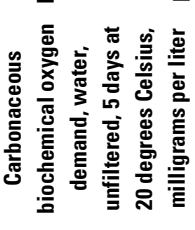

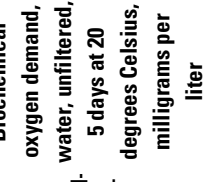

$-$

:

3)

؛.

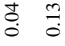

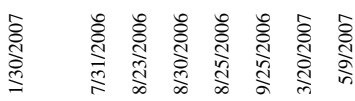

高

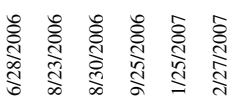

$\stackrel{9}{0}$

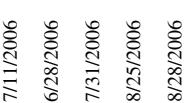

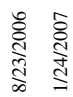

离

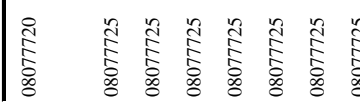

Im lm

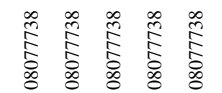

魚

III 


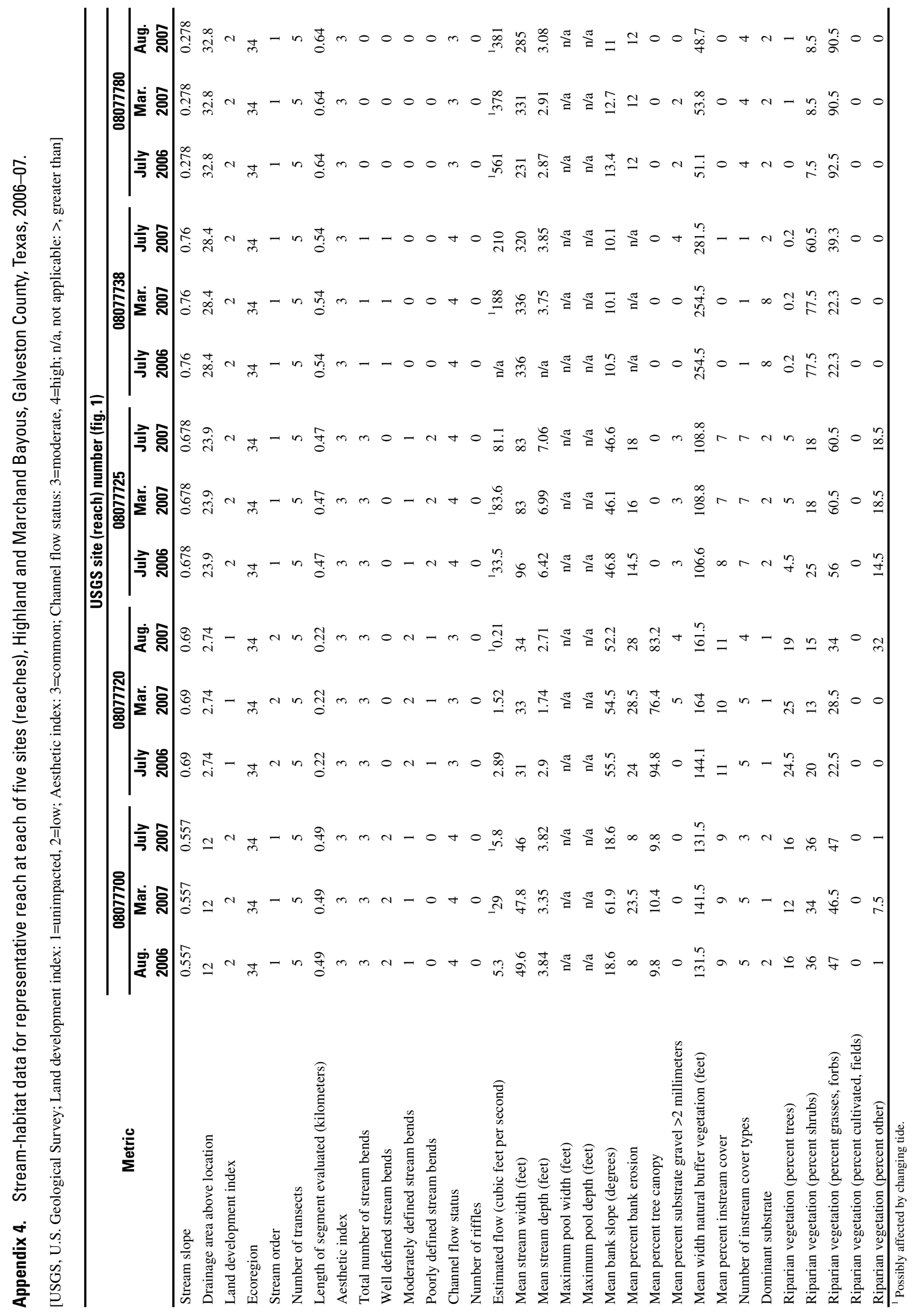




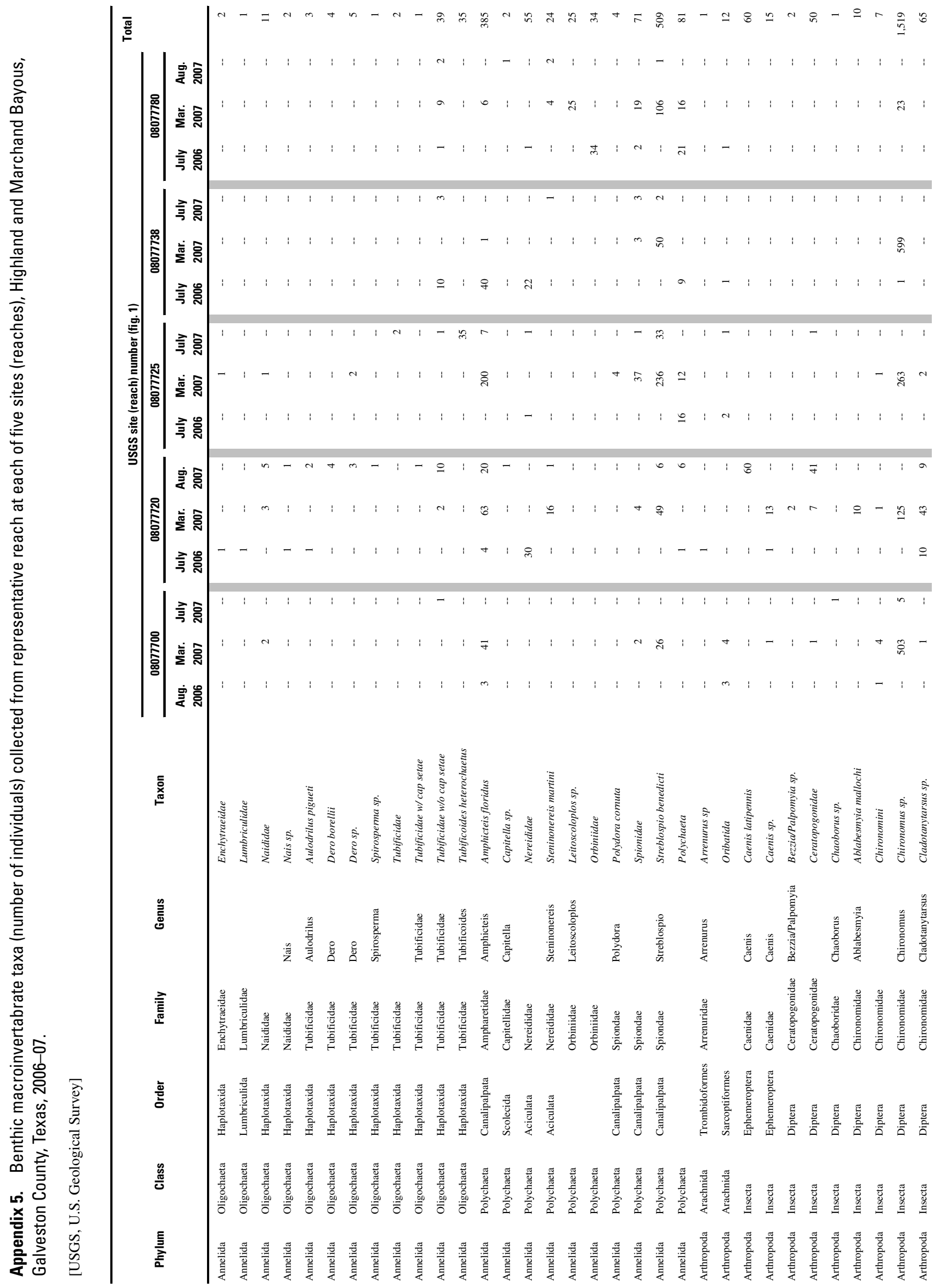




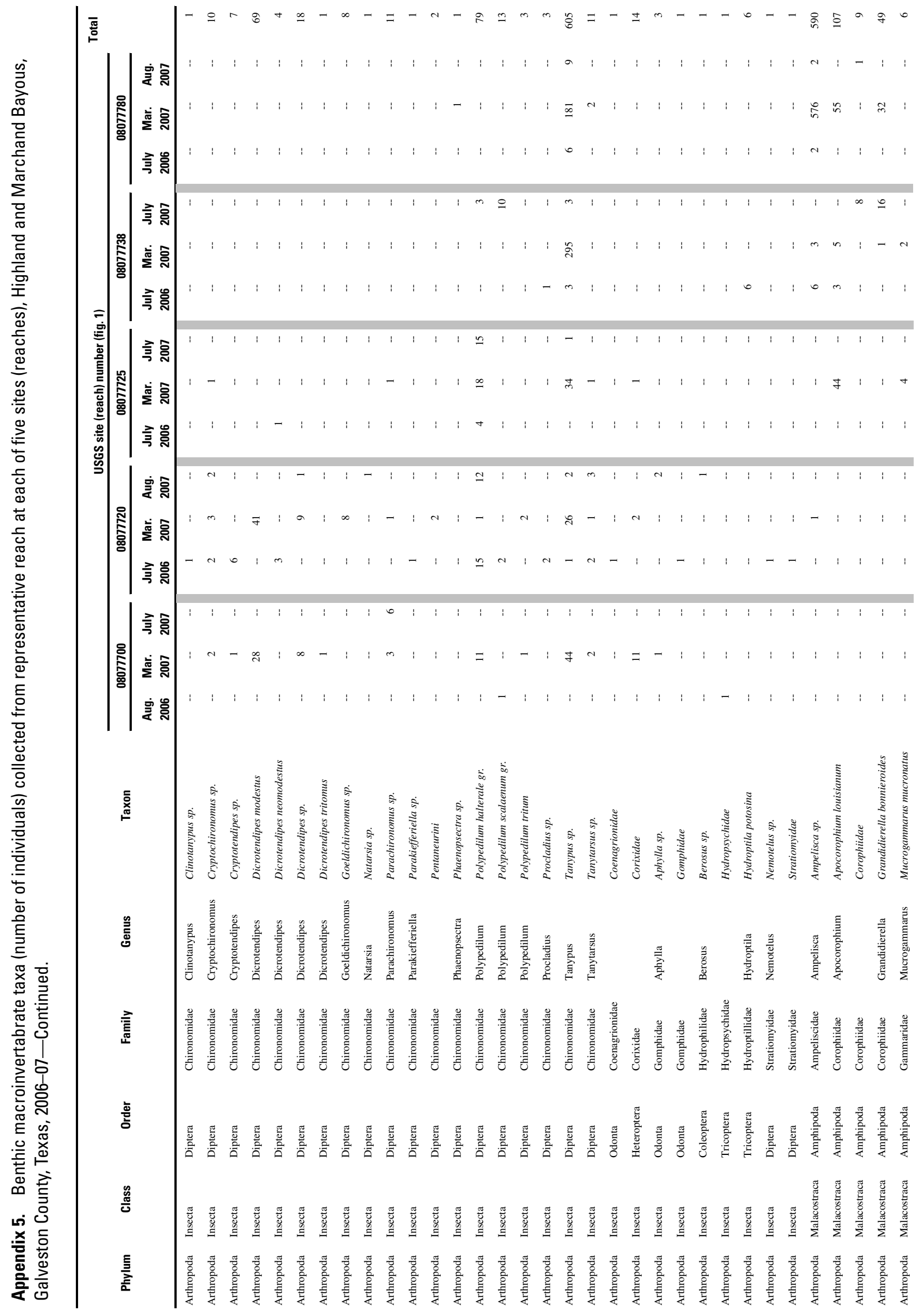




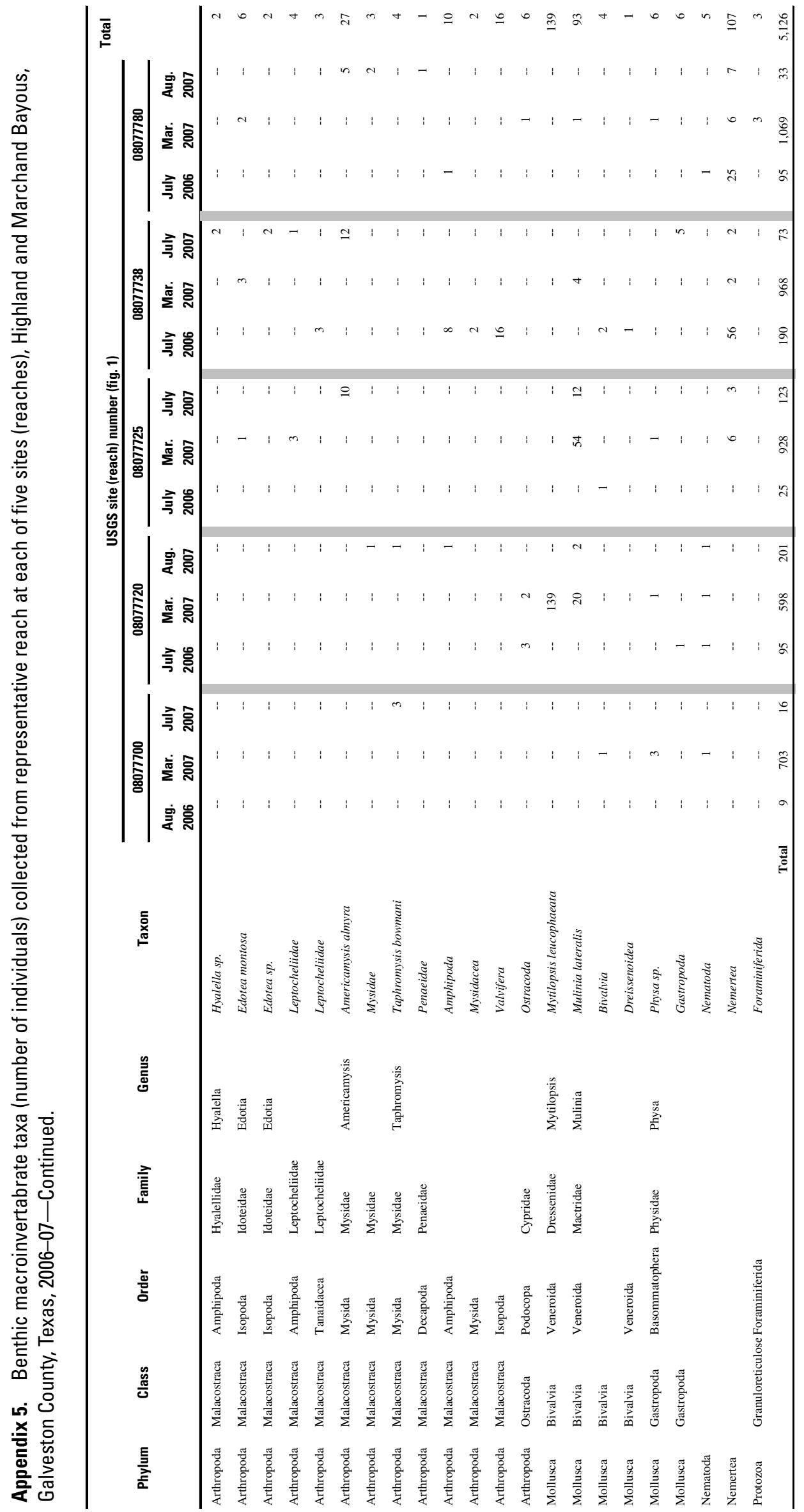




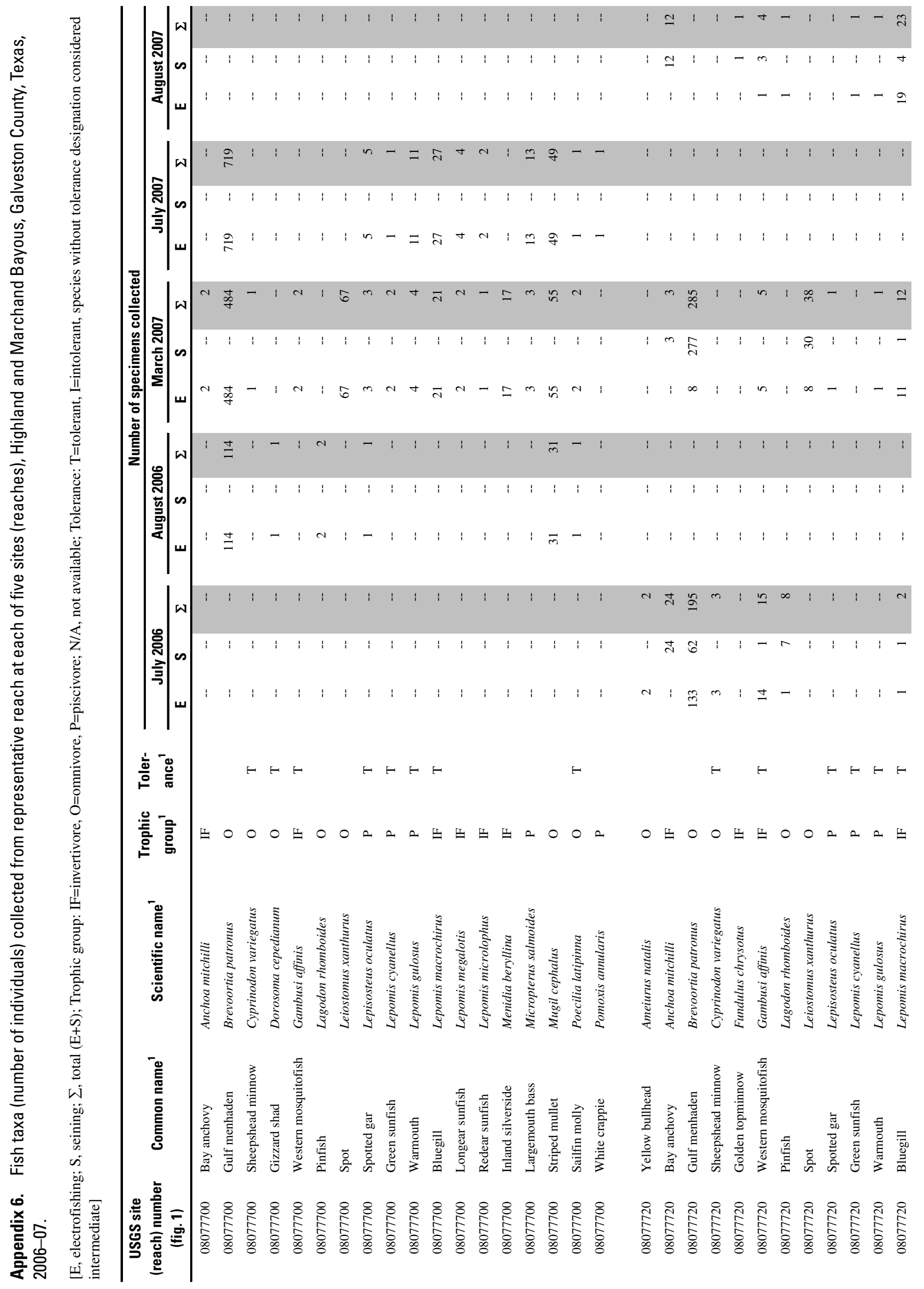




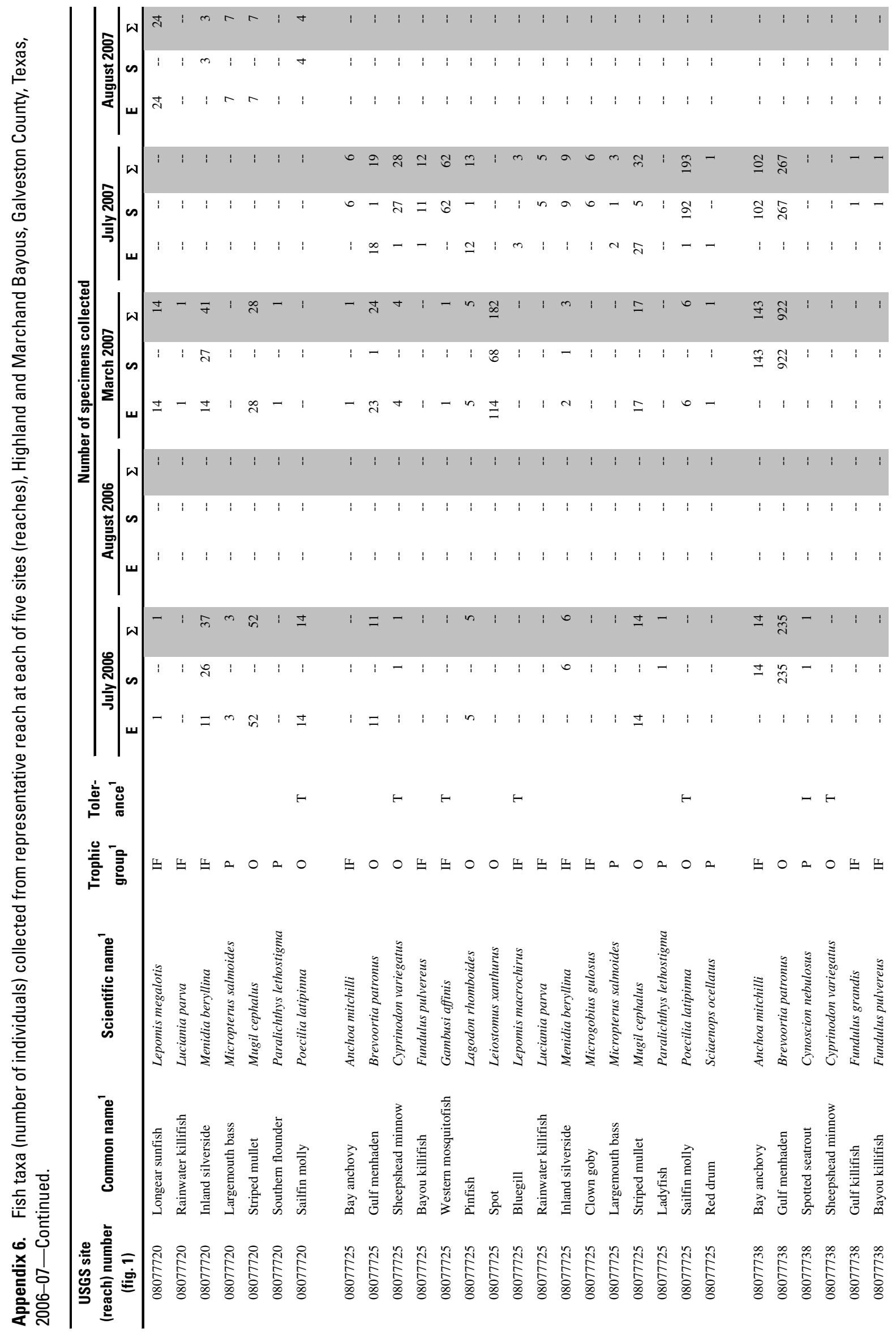




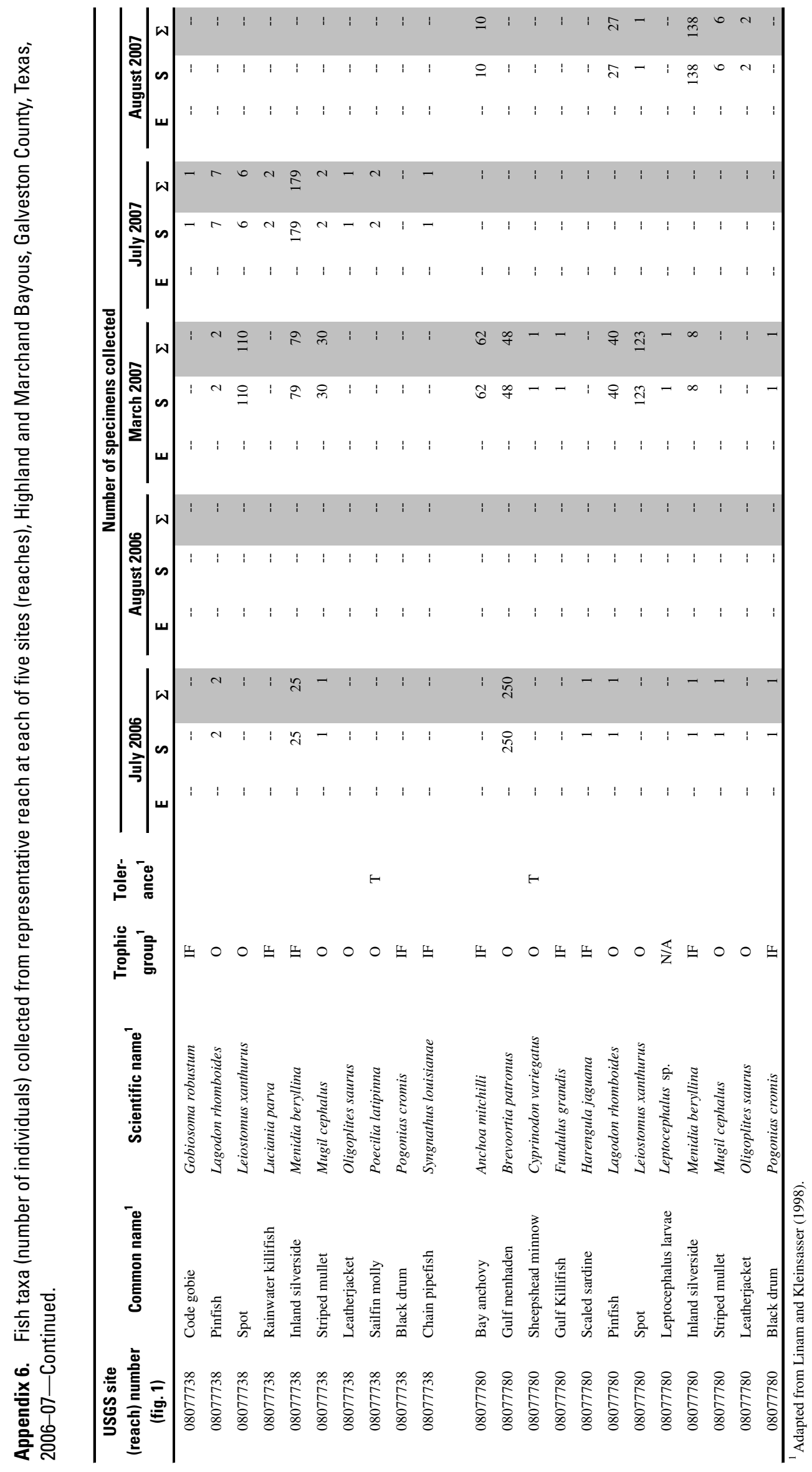


Publishing support provided by

Lafayette Publishing Service Center

Information regarding water resources in Texas is available at http://tx.usgs.gov/ 


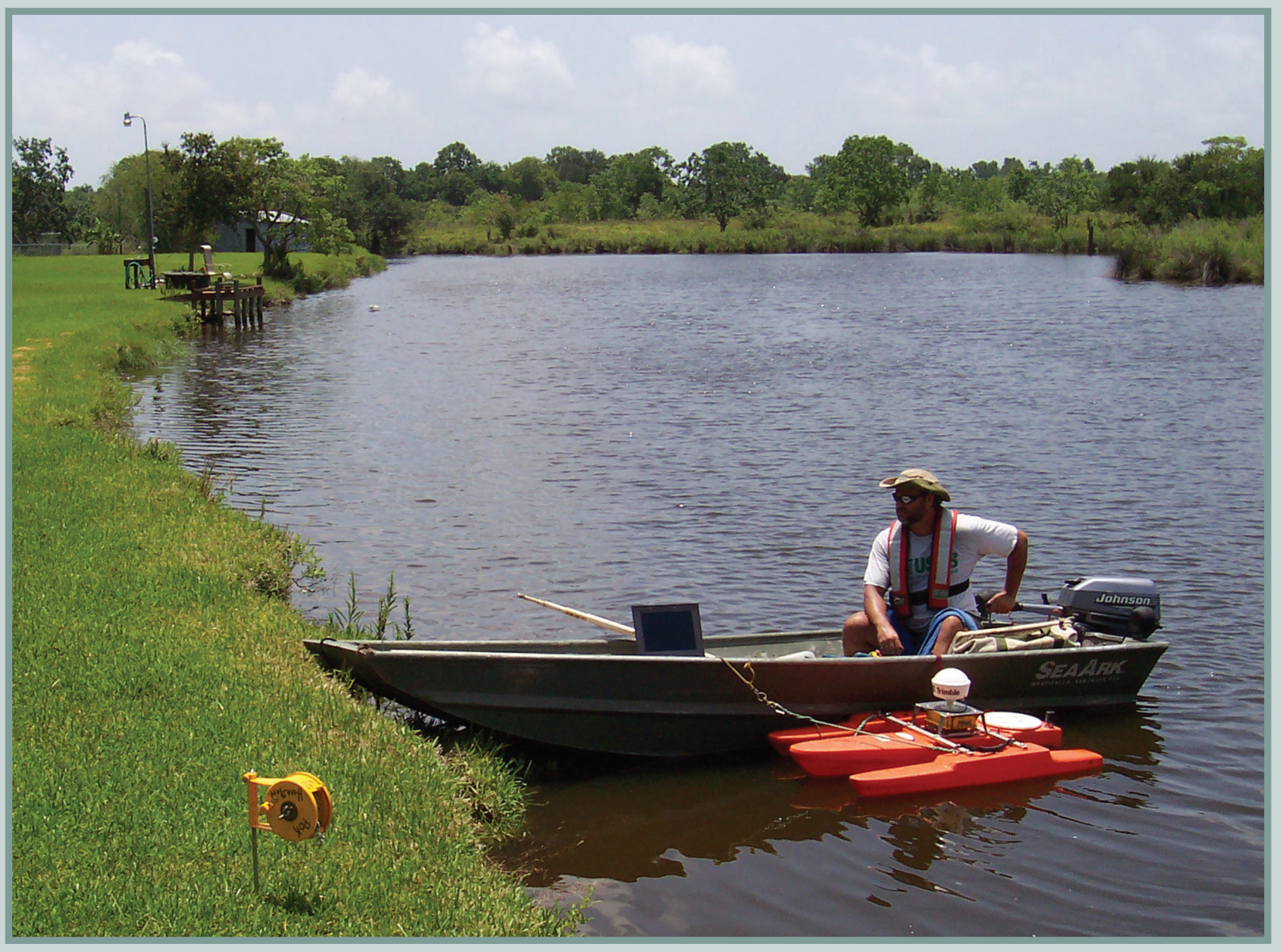

Printed on recycled paper 